Environmental Analysis of

Lower Pueblo/Lower Los Alamos Canyon,

Los Alamos, New Mexico

Roger W. Ferenbaugh

Thomas E. Buhl

Alan K. Stoker

Naomi M. Becker

John C. Rodgers

Wayne R. Hansen

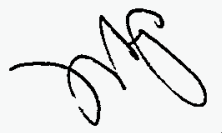




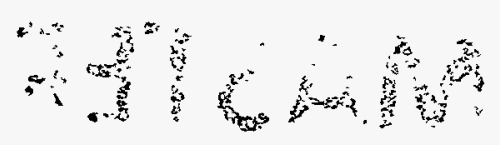




\section{DISCLAIMER}

This report was prepared as an account of work sponsored by an agency of the United States Government. Neither the United States Government nor any agency thereof, nor any of their employees, make any warranty, express or implied, or assumes any legal liability or responsibility for the accuracy, completeness, or usefulness of any information, apparatus, product, or process disclosed, or represents that its use would not infringe privately owned rights. Reference herein to any specific commercial product, process, or service by trade name, trademark, manufacturer, or otherwise does not necessarily constitute or imply its endorsement, recommendation, or favoring by the United States Government or any agency thereof. The views and opinions of authors expressed herein do not necessarily state or reflect those of the United States Government or any agency thereof. 


\section{DISCLAIMER}

Portions of this document may be illegible in electronic image products. Images are produced from the best available original document. 


\section{PREFACE}

This report originally was prepared in 1984 under the auspices of the Formerly Utilized Sites Remedial Action Program (FUSRAP) but was never published. It is now being published as part of the characterization phase of the Los Alamos National Laboratory Environmental Restoration (ER) Program, as it contains data from Los Alamos Canyon that is relevant to ER Program implementation. Although the methodology for dose calculations has changed since the report originally was prepared, the original dose calculations are presented herein. The conclusions are the same regardless of the dose calculation method employed. 

1.0 INTRODUCTION AND BACKGROUND 2

1.1 The FUSRAP Program 2

1.2 Preferred Alternative 2

2.0 ACID/PUEBLO/LOWER LOS ALAMOS CANYON 3

2.1 Summary History and Description 3

2.1.1 Description 3

2.1.2 History of Site 3

2.1.2.1 Operations and Waste Disposal 3

2.1.2.2 Decontamination and Decommissioning 13

2.1.2.3 Land Ownership 13

2.2 Need for Action 14

2.2.1 Potential Dose Evaluation and Interpretation 14

2.2.1.1 Bases of Dose Estimates and Comparisons $\quad 15$

2.2.1.2 Potential Doses Under Present Conditions 15

2.2.1.3 Modeling of the Pueblo/Los Alamos Canyon System 19

2.2.1.4 Potential Doses Under Future Conditions 22

2.2.1.5 Potential Doses Associated with Cleanup 28

2.2.1.6 Potential Doses Associated with the Construction of a Sediment Trap 32

2.2.2 Health Risks from Pueblo/Los Alamos Residual Radioactivity 34

2.2.2.1 Risks from Existing Conditions 34

2.2.2.2 Risks from Cleanup 35

2.2.2.3 Risks from Construction of the Sediment Trap 35

2.2.2.4 Risks under the No-Action Alternative 37

2.2.3 Criteria Upon Which Cleanup Action is Based 37

2.3 Other Agencies Involved in Implementation of the Proposed Action 39

3.0 ALTERNATIVES 40

3.1 Alternative I-Construction of a Sediment Trap in

Lower Pueblo Canyon

3.2 Alternative II-Cleanup of Lower Pueblo and Lower Los Alamos Canyons 41

3.3 Alternative III-No Action (Preferred Alternative) 41

4.0 AFFECTED ENVIRONMENT 41

4.1 Land Use 41

4.1.1 Lower Pueblo Canyon 41

4.1.2 Lower Los Alamos Canyon $\quad 42$ 
$\begin{array}{lll}4.1 .3 & \text { TA-54 } & 42\end{array}$

4.1.4 Transportation Route $\quad 42$

4.2 Socioeconomics 42

4.2.1 Demography $\quad 42$

4.2.2 Economy 44

4.2.3 Institutional 44

4.2.4 Community Services $\quad 46$

4.2.5 Archaeology 46

4.3 Soils and Geology Soils $\quad 47$

$\begin{array}{lll}4.3 .1 & \text { Soils } & 47\end{array}$

$\begin{array}{lll}4.3 .2 \text { Geology } & 48\end{array}$

4.4 Climatology 51

4.4.1 General Climate $\quad 51$

4.4.2 Air Quality $\quad 52$

4.5 Hydrology and Water Quality 53

4.6 Biotic Environmental Factors 54

$\begin{array}{lll}4.6 .1 & \text { General Ecology } & 54\end{array}$

$\begin{array}{lll}4.6 .2 & \text { Plants } & 54\end{array}$

4.6.2.1 Characterization $\quad 54$

4.6.2.2 Rare and Endangered Species $\quad 55$

$\begin{array}{ll}4.6 .3 \text { Animals } & 55\end{array}$

4.6.3.1 Characterization $\quad 55$

4.6.3.2 Rare and Endangered Species $\quad 57$

$4.7 \quad$ Summary of Radiological Conditions $\quad 57$

$\begin{array}{ll}\text { 4.7.1 Radioactivity in Soils and Sediments } & 57\end{array}$

$\begin{array}{lll}\text { 4.7.1.1 Present Conditions } & 57\end{array}$

4.7.1.2 Concentrations $\quad 57$

4.7.1.3 Estimated Inventory $\quad 67$

4.7.2 Airborne Radioactivity $\quad 69$

4.7.2.1 Present Conditions 69

4.7.2.2 Measurements 69

4.7.2.3 Theoretical Estimates $\quad 74$

4.7.3 External Penetrating Radiation 76

$\begin{array}{lll}5.0 & \text { ENVIRONMENTAL CONSEQUENCES } & 79\end{array}$

5.1 Alternative I-Construction of a Sediment Trap in
Lower Pueblo Canyon

$\begin{array}{lll}5.1 .1 & \text { Radiological Consequences } & 79\end{array}$

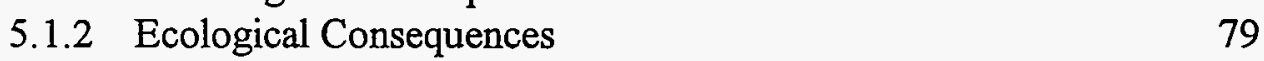

$\begin{array}{ll}\text { 5.1.3 Land Use Impacts } & 79\end{array}$

5.1.4 Socioeconomic Effects $\quad 80$

5.1.5 Risk to Individual Health and Safety $\quad 80$ 
5.2 Alternative II-Cleanup of Lower Pueblo and

Lower Los Alamos Canyons

5.2.1 Radiological Consequences $\quad 81$

$\begin{array}{ll}\text { 5.2.2 Ecological Consequences } & 81\end{array}$

5.2.3 Land Use Impacts $\quad 81$

5.2.4 Socioeconomic Effects $\quad 81$

5.2.5 Risk to Individual Health and Safety 82

5.3 Alternative III-No Action (Preferred Alternative) 82

5.3.1 Radiological Consequences $\quad 82$

$\begin{array}{ll}\text { 5.3.2 Ecological Consequences } & 82\end{array}$

5.3.3 Land Use Impacts $\quad 82$

5.3.4 Socioeconomic Effects $\quad 82$

5.3.5 Risk to Individual Health and Safety 82

$\begin{array}{lc}\text { REFERENCES } & 83\end{array}$

APPENDIXES

A. PLANTS OF PUEBLO CANYON 88

B. PLANTS ENUMERATED IN NEW MEXICO STATUTE 45-1-11 THAT ARE KNOWN TO OCCUR IN LOS ALAMOS COUNTY 91

C. ANIMALS OF THE LOS ALAMOS ENVIRON 95

D. DOSE CALCULATIONS FOR LOWER PUEBLO CANYON/LOWER 107 LOS ALAMOS CANYON

\section{FIGURES}

1. Regional location of study area. $\quad 4$

2. Physiographic setting of Los Alamos County. 5

3. Former liquid waste handling facilities and relation to effluent receiving canyons. 6

4. Land ownership or management in study area. 7

5. Aerial view of Los Alamos and study area looking east. 9

6. Location of TA-54 and transportation route from lower Pueblo and lower Los Alamos canyons. 43

7. Geologic map of a part of the Pajarito Plateau in the Los Alamos area. 49

8. Concentration of ${ }^{239} \mathrm{Pu}$ on soils and sediments by location. 64

9. Estimated inventory of ${ }^{239} \mathrm{Pu}$ on soils and sediments by location. 68

10. Concentrations of airborne ${ }^{239} \mathrm{Pu}$ at three locations during 1976-1977. 72 


\section{TABLES}

I. RADIOACTIVITY CONTENT OF EFFLUENTS RELEASED TO ACID CANYON.

II. RADIOACTIVITY CONTENT OF TREATED EFFLUENTS RELEASED TO DP CANYON FROM TA-21.

III. MAXIMUM LIKELY INCREMENTS OF RISK BASED ON EXPOSURE ATTRIBUTABLE TO RESIDUAL RADIOACTIVITY IN LOWER PUEBLO AND LOWER LOS ALAMOS CANYONS.

IVa. ESTIMATED AVERAGE RADIONUCLIDE DISCHARGES FROM LOS ALAMOS CANYON AND BACKGROUND RADIONUCLIDE FLUX IN THE RIO GRANDE.

IVb. RADIONUCLIDE DISCHARGES FROM LOS ALAMOS CANYON. 27

V. POTENTIAL DOSES ASSOCIATED WITH CLEANUP. 29

VI. RISK COMPARISON DATA. 36

VII. PROPOSED CRITERIA FOR SOIL CLEANUP ACTION. 38

VIII. COMMON HERBS AND SHRUBS OF THE LOWER MIDDLE PUEBLO CANYON AREA.

IX. MAMMALS TRAPPED OR SIGHTED IN ACID/PUEBLO CANYON. 58

$X$. STATE-LISTED ENDANGERED ANIMAL SPECIES FOR

NORTH CENTRAL NEW MEXICO.

XI. SEDIMENT ANALYSES FROM LOWER PUEBLO CANYON. 60

XII. SEDIMENT ANALYSES FROM LOWER LOS ALAMOS CANYON. 61

XIII. SUMMARY OF DATA.

XIV. RELATIONSHIP OF ${ }^{239} \mathrm{Pu}$ AND OTHER TRANSURANIC CONCENTRATIONS

66

XV. ANNUAL AVERAGE ${ }^{239} \mathrm{Pu}$ AIR CONCENTRATIONS.

XVI. POTENTIAL CONTRIBUTIONS OF RESUSPENSION TO

${ }^{239} \mathrm{Pu}$ AIRBORNE RADIOACTIVITY.

XVII. EXTERNAL PENETRATING RADIATION MEASUREMENTS AND ESTIMATES OF CONTRIBUTIONS FROM RESIDUAL RADIOACTIVITY.

APPENDIX TABLES

C-I. MAMMALS

C-II. AMPHIBIANS AND REPTILES 98

C-III. FISH

C-IV. BIRDS 99

C-V. INVERTEBRATES 106

D-I. SOIL AND SEDIMENT CONCENTRATIONS USED IN DOSE CALCULATIONS 
D-II. PARAMETERS USED IN DOSE CALCULATIONS FOR CLEANUP WORKERS

D-III. PARAMETERS USED TO ESTIMATE DOSES FROM USE OF WATER FROM THE RIO GRANDE 


\title{
ENVIRONMENTAL ANALYSIS OF LOWER PUEBLO/LOWER LOS ALAMOS CANYON, LOS ALAMOS, NEW MEXICO
}

\author{
by
}

Roger W. Ferenbaugh, Thomas E. Buhl, Alan K. Stoker, Naomi M. Becker, John C. Rodgers, and Wayne R. Hansen

\begin{abstract}
The radiological survey of the former radioactive waste treatment plant site (TA-45), Acid Canyon, Pueblo Canyon, and Los Alamos Canyon found residual contamination at the site itself and in the channel and banks of Acid, Pueblo, and lower Los Alamos Canyons all the way to the Rio Grande. The largest reservoir of residual radioactivity is in lower Pueblo Canyon, which is on DOE property. However, residual radioactivity does not exceed proposed cleanup criteria in either lower Pueblo or lower Los Alamos Canyons. The three alternatives proposed are (1) to take no action, (2) to construct a sediment trap in lower Pueblo Canyon to prevent further transport of residual radioactivity onto San Ildefonso Indian Pueblo land, and (3) to clean the residual radioactivity from the canyon system. Alternative II, to cleanup the canyon system, is rejected as a viable alternative. Thousands of truckloads of sediment would have to be removed and disposed of, and this effort is unwarranted by the low levels of contamination present. Residual radioactivity levels, under either present conditions or projected future conditions, will not result in significant radiation doses to persons exposed. Modeling efforts show that future transport activity will not result in any residual radioactivity concentrations higher than those already existing. Thus, although construction of a sediment trap in lower Pueblo Canyon is a viable alternative, this effort also is unwarranted, and the noaction alternative is the preferred alternative.
\end{abstract}




\subsection{INTRODUCTION AND BACKGROUND}

\subsection{The FUSRAP Program}

In 1976, the Energy Research and Development Administration (ERDA) identified Acid/Pueblo Canyon as one of the locations to be reevaluated under FUSRAP. The locations identified under FUSRAP auspices were to be resurveyed for residual radioactivity using modern instrumentation and analytical methods. The resurveys are the bases for determining whether further remedial action is necessary. The Acid/Pueblo Canyon resurvey was performed by the Los Alamos National Laboratory under contract to ERDA and, subsequently, the Department of Energy (DOE). The survey included the site of the former radioactive liquid waste treatment plant and associated vehicle decontamination facility (collectively designated as TA-45), the treated and untreated waste discharge outfalls, and the Acid/Pueblo/Los Alamos Canyon system into which the outfall effluents passed.

The results of the survey ${ }^{1}$ indicated subsurface residual radioactivity at TA-45 and along the path of the untreated waste line. Surface residual radioactivity was found at TA-45, in the area of the untreated waste line outfall, on the cliff face where the treated wastes were discharged, and throughout Acid/Pueblo/lower Los Alamos Canyon. Alternatives for TA45/Acid/Middle Pueblo Canyon were considered in a separate report. ${ }^{2}$ The present report considers the environmental analysis of lower Pueblo/lower Los Alamos Canyon.

\section{$1.2 \quad$ Preferred Alternative}

The three alternatives considered for lower Pueblo/lower Los Alamos Canyon are no action, construction of a sediment trap in lower Pueblo Canyon, and cleanup of residual radioactivity from the canyon system.

The preferred alternative is the no-action alternative. Cleanup of the canyons is both impractical, because of the extraordinarily large volume of sediments involved, and unnecessary, because the residual radioactivity remaining in the canyons is so dispersed among the sediments that the incremental dose attributable to it by any plausible pathway is insignificant. Construction of a sediment trap is unnecessary because the braided stream channel in lower Pueblo Canyon above the culvert under State Road 4 acts as a natural sediment trap. This is where the largest reservoir of residual radioactivity-containing 
sediments is located. Furthermore, modeling efforts show that future transport will not result in any residual radioactivity concentrations large enough to cause a significant incremental dose.

\subsection{ACID/PUEBLO/LOWER LOS ALAMOS CANYON}

\subsection{Summary History and Description}

2.1.1 Description. Los Alamos County is located in North Central New Mexico, about $100 \mathrm{~km} \mathrm{NNE}$ of Albuquerque and $40 \mathrm{~km} \mathrm{NW}$ of Santa Fe by air, as shown in Fig. 1 . Acid Canyon is a small tributary near the head of Pueblo Canyon, which, in turn, connects with Los Alamos Canyon near the eastern edge of the Pajarito Plateau (Fig. 2). Lower Pueblo/lower Los Alamos Canyon is located across Sections 17 through 20 at T19N, R7E. Lower Pueblo Canyon is owned by the DOE, and lower Los Alamos Canyon is part of the San Ildefonso Indian Pueblo. Both are in Santa Fe County. Lower Pueblo Canyon connects with lower Los Alamos Canyon at the junction of State Road 4 and State Road 502, about 8 $\mathrm{km}$ east of the community of Los Alamos and $6 \mathrm{~km}$ north of the community of White Rock. Figure 3 shows the location of the former TA-45 radioactive waste treatment plant site relative to surrounding features in the Los Alamos townsite and the relative locations of Acid, Pueblo, and Los Alamos Canyons. Figure 4 shows the ownership of land relative to the canyons.

\subsubsection{History of Site. ${ }^{1}$}

2.1.2.1 Operations and Waste Disposal. The radioactive liquid wastes handled at the TA-45 site resulted from work started in 1943 as part of Project Y of the US Army's secret Manhattan Engineer District. The purpose of the project was to develop a nuclear weapon. Los Alamos was selected in November 1942 as the site for Project Y. The War Department acquired the Los Alamos Ranch School, which consisted of 54 buildings and about $14.6 \mathrm{~km}^{2}$ of school and other private holdings. About $186 \mathrm{~km}^{2}$ of additional land were acquired from other government agencies. The total land area included essentially all of what is in the present-day Los Alamos County. The first construction contract was let in December 1942 and in January 1943 the University of California assumed responsibility for operating the 


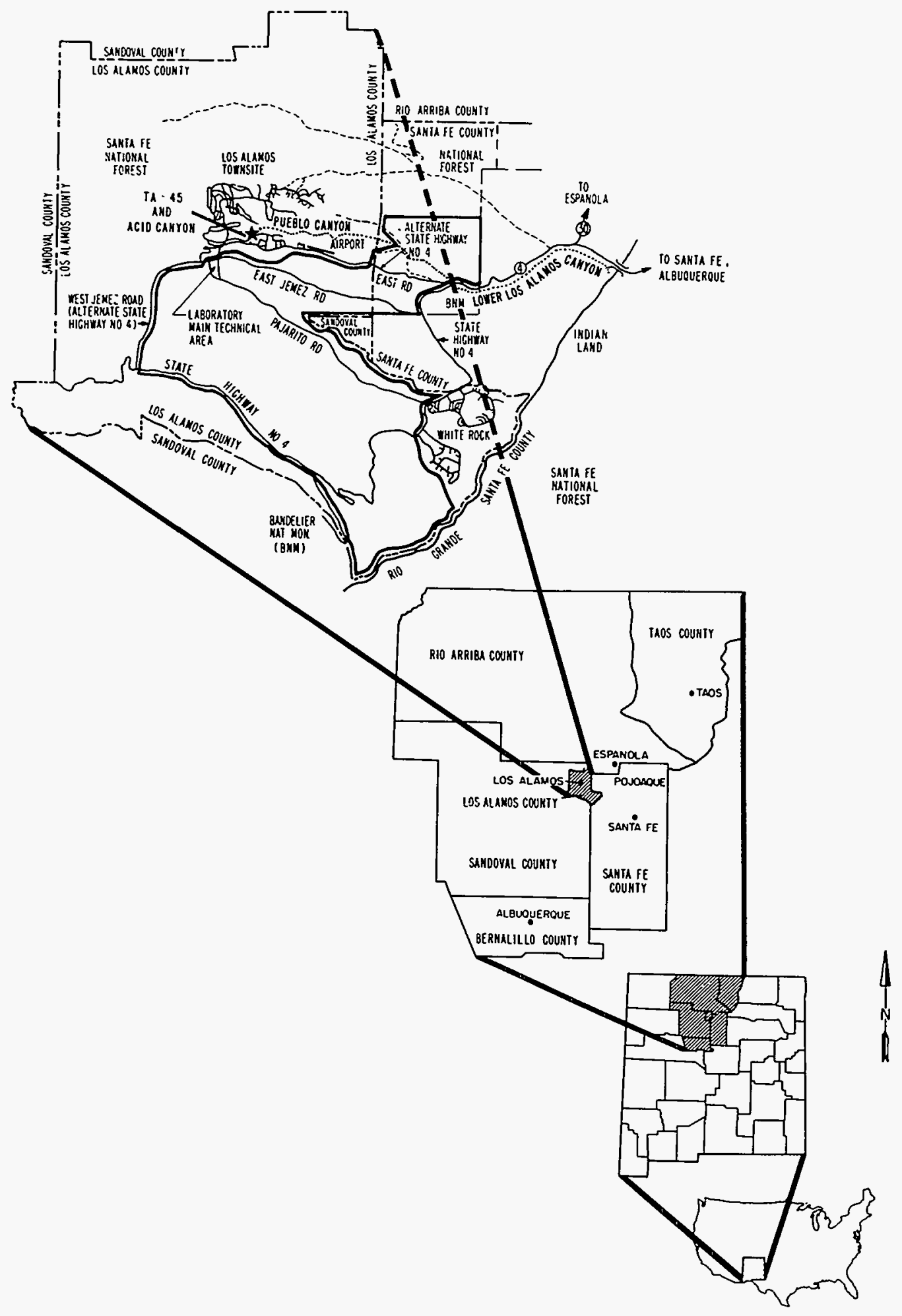

Fig. 1

Regional location of study area. 


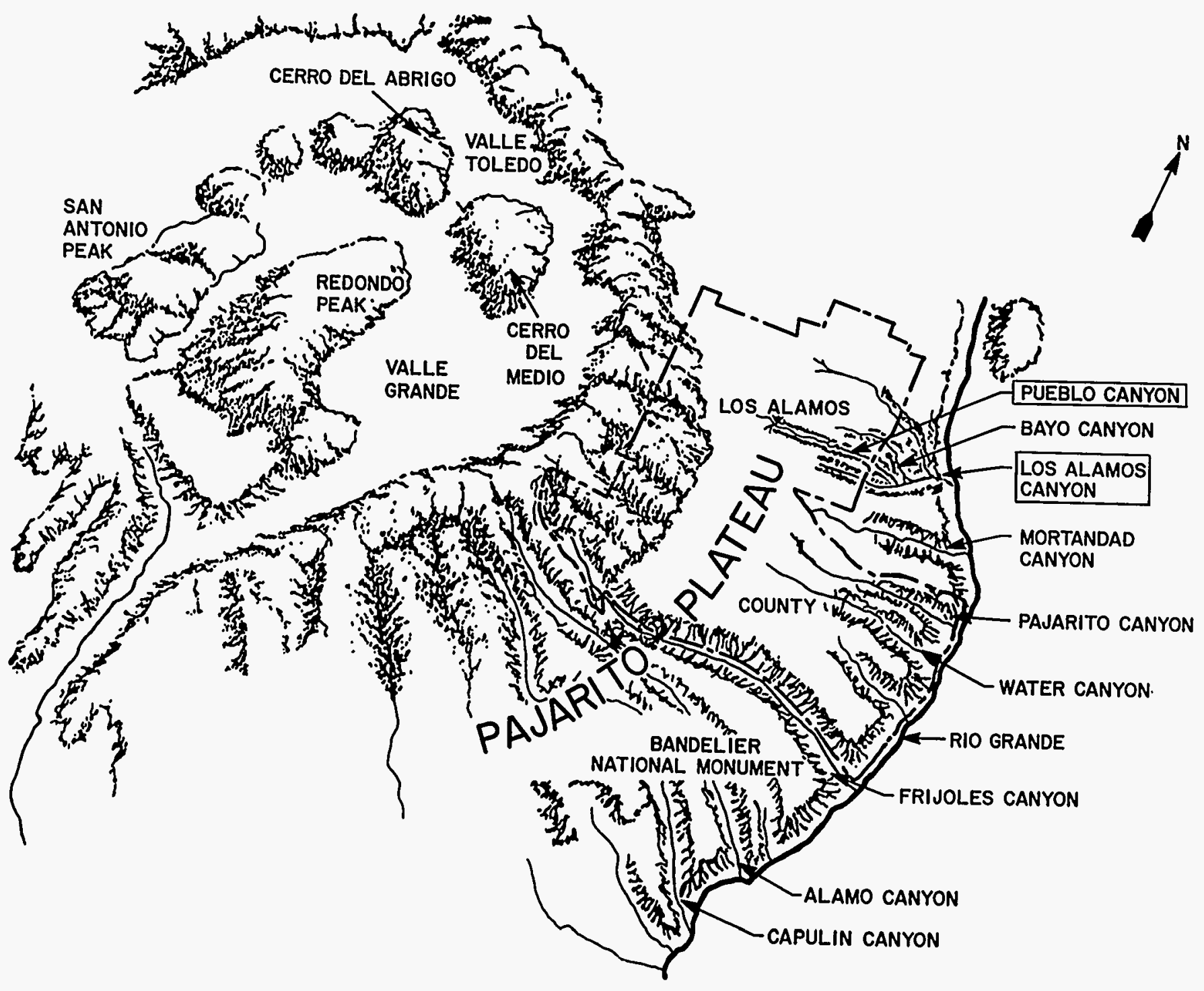

Fig. 2

Physiographic setting of Los Alamos County. 


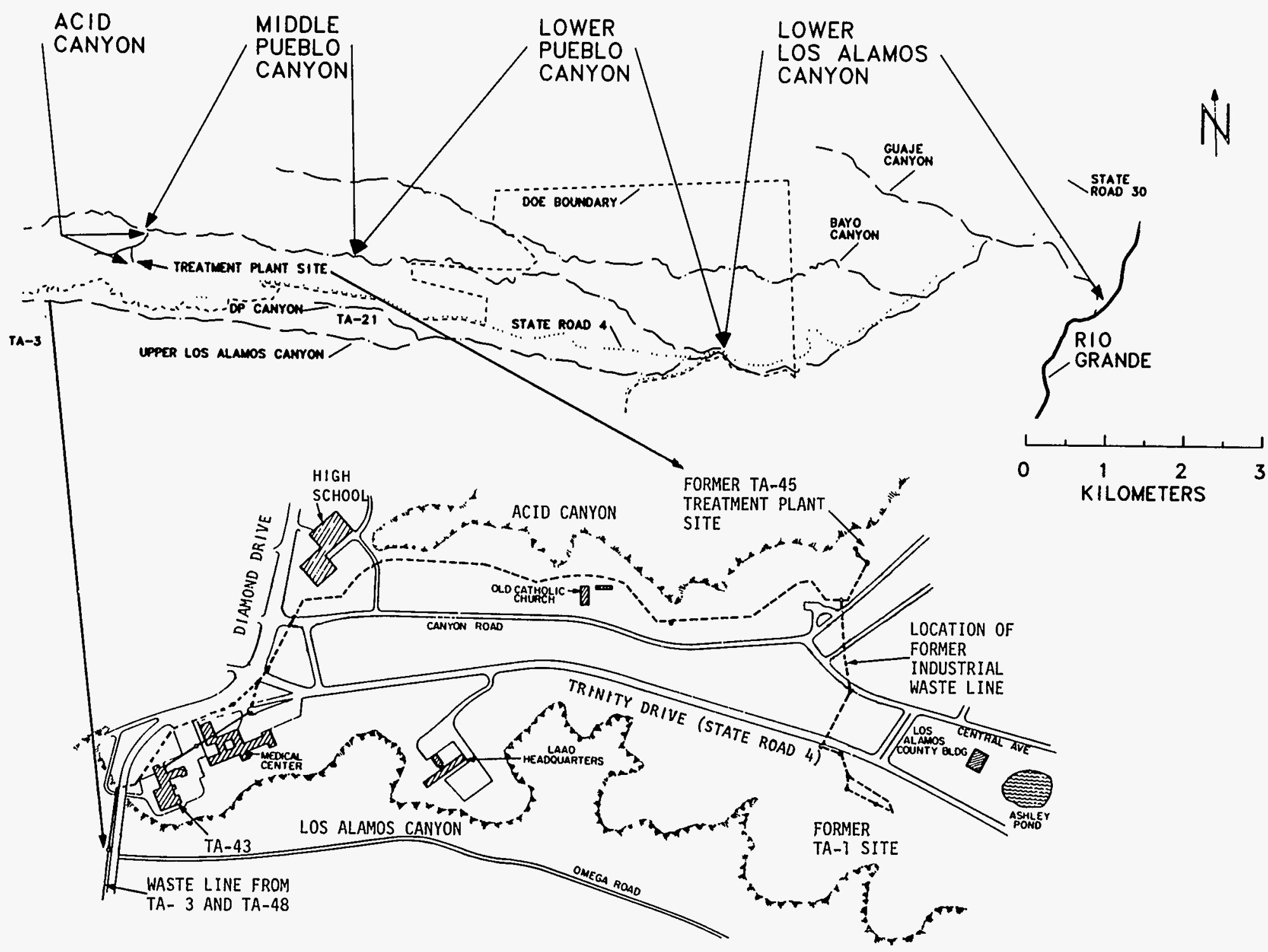

Fig. 3

Former liquid waste handling facilities and relation to effluent receiving canyons. 


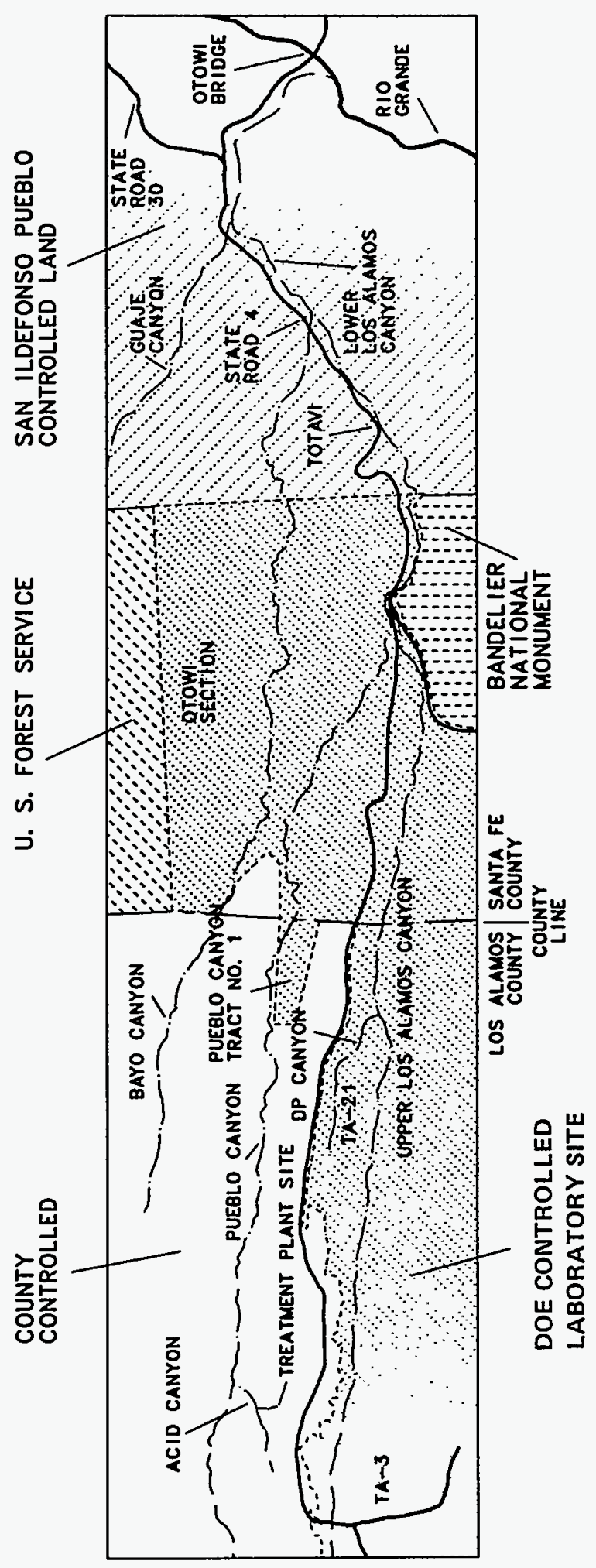

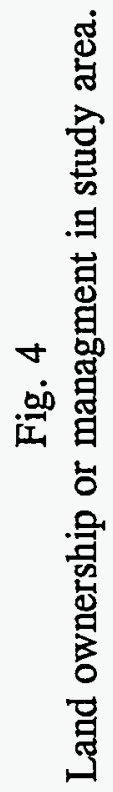


Laboratory. The first technical facilities, known as the Main Technical Area, or TA-1, were constructed on about $0.16 \mathrm{~km}^{2}$ near the then-existing Ranch School facilities around Ashley Pond and along part of the north rim of Los Alamos Canyon. Buildings in which general laboratory or process chemistry and radiochemistry wastes were produced were served by industrial waste lines known as acid sewers. Ultimately, all such industrial wastes flowed into a main acid sewer that extended generally north to a discharge point at the edge of Acid Canyon (Figs. 3 and 5).

The untreated liquid waste discharge started in late 1943 or early 1944 and continued through April, 1951. These effluents contained a variety of radioactive isotopes from the research and processing operations associated with nuclear weapons development. No detailed analyses are available, but the radioisotopes of interest included tritium and isotopes of strontium, cesium, uranium, plutonium, and americium. From limited data, estimates were made of the major isotopes released in the untreated effluents. These estimates are summarized in Table I. The plutonium concentrations in these releases must have averaged about $1000 \mathrm{pCi} / \ell$ with maximum concentrations of about $10,000 \mathrm{pCi} / \ell$.

In 1948, a joint effort was started between the Laboratory and the US Public Health Service to develop a method for removing plutonium and other radionuclides from radioactive liquid waste. Bench-scale experiments showed that conventional physicochemical water treatment methods could be modified for treatment of radioactive waste. By June, 1951, a treatment plant, identified as TA-45, had been designed and constructed. It began processing radioactive and other laboratory wastes by a flocculation-sedimentation-filtration process. The final effluent, containing about $1 \%$ of the influent plutonium concentration, was sampled before release into Acid Canyon. The ${ }^{239} \mathrm{Pu}$ concentrations in the effluent ranged from about 20 to $150 \mathrm{pCi} / \ell$ while the plant was in operation. Summary data on the radioactivity content of the released effluent are in Table I. The plant typically removed $98 \%$ to $99 \%$ of the mass of plutonium in the influent. Thus, a total of about 0.34 gram of plutonium was released in treated effluent during the 14 years that the plant was in operation, compared to an estimated 1.9 grams released in untreated waste during the previous 8 years.

From startup until mid-1953, the TA-45 plant treated liquid wastes only from the original Main Technical Area, TA-1. Starting in June 1953 additional radioactive liquid wastes were piped to TA-45 from the new laboratory complex (TA-3) south of Los Alamos 


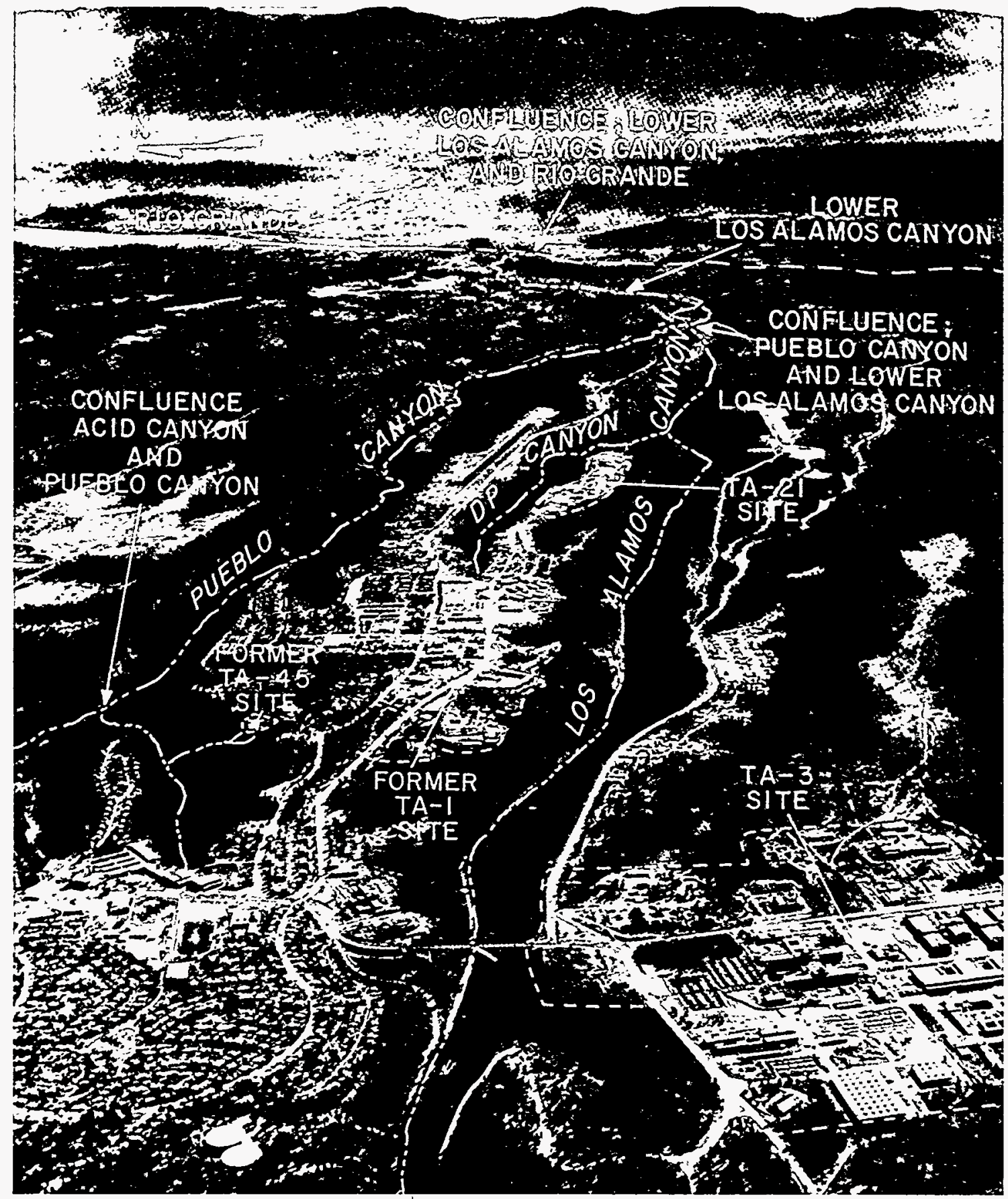

Fig. 5

Aerial view of Los Alamos and study area looking east. 
TABLE I

RADIOACTIVITY CONTENT OF EFFLUENTS RELEASED TO ACID CANYON ${ }^{\mathrm{a}, \mathrm{b}}$

Untreated Effluents, 1943 through April 1951

\begin{tabular}{|c|c|c|c|c|}
\hline & & & uries) & \\
\hline & ${ }^{3} \mathrm{H}^{\mathrm{c}}$ & ${ }^{89} \mathrm{Sr}$ & ${ }^{90} \mathrm{Sr}$ & $\mathrm{Pu}^{\mathrm{b}}$ \\
\hline Estimated Total Releases & 18.25 & 0.25 & 0.094 & 0.15 \\
\hline Activity Decayed to Dec. $1977^{\mathrm{e}}$ & 3.4 & 0 & 0.046 & 0.15 \\
\hline
\end{tabular}

Treated Effluents, April 1951 through June 1964

\begin{tabular}{|c|c|c|c|c|}
\hline $\begin{array}{l}\text { Annual } \\
\text { Release }\end{array}$ & ${ }^{3} \mathrm{H}^{\mathrm{c}}$ & $\begin{array}{c}\text { Unidentified } \\
\text { Gross } \alpha\end{array}$ & $\begin{array}{l}\text { Unidentified } \\
\text { Gross } \beta \& \gamma\end{array}$ & \\
\hline 1951 & 3 & 0.0024 & & $\overline{0}$ \\
\hline 1952 & 3 & 0.0041 & & 0 \\
\hline 1953 & 3 & 0.0038 & & \\
\hline 1954 & 3 & 0.0044 & & 0 . \\
\hline 1955 & 3 & 0.0041 & & 0 . \\
\hline 1956 & 3 & 0.0060 & & \\
\hline 1957 & 3 & 0.0087 & & 0 . \\
\hline 1958 & 3 & 0.0038 & & 0 . \\
\hline 1959 & 3 & 0.0018 & & 0 . \\
\hline 1960 & 3 & 0.0035 & 1.251 & \\
\hline 1961 & 3 & 0.0093 & 0.505 & \\
\hline 1962 & 3 & 0.0074 & 1.222 & 0. \\
\hline 1963 & 3 & 0.0072 & 0.804 & 0 . \\
\hline 1964 & 1.2 & 0.0001 & 0.0001 & 0.0 \\
\hline Total Release & 40.2 & 0.0666 & 3.78 & \\
\hline $\begin{array}{l}\text { Activity Decayed } \\
\text { to Dec. } 1977^{\mathrm{e}}\end{array}$ & 13.1 & f & $f$ & 0.0 \\
\hline \multicolumn{5}{|c|}{ 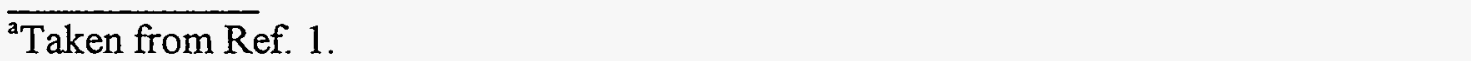 } \\
\hline \multicolumn{5}{|c|}{$\begin{array}{l}\text { 'Measured and estimated data as compiled for and summarized in the US DOE Onsite } \\
\text { Discharge Information System (ODIS). }\end{array}$} \\
\hline \multicolumn{5}{|c|}{${ }^{c}$ All tritium values estimated. } \\
\hline \multicolumn{5}{|c|}{$\begin{array}{l}\text { Total plutonium, predominately }{ }^{239} \mathrm{Pu} \text {, but includes small amounts of other isotopes. } \\
\text { Reported in ODIS as }{ }^{239} \mathrm{Pu} \text {. }\end{array}$} \\
\hline \multicolumn{5}{|c|}{ Decay based on year of release and appropriate half-life. } \\
\hline \multicolumn{5}{|c|}{ No estimate of decayed value made because data on isotopic mixtures are not available. } \\
\hline \multicolumn{5}{|c|}{$\begin{array}{l}\text { The gross } \alpha \text { is assumed to be predominantly plutonium and uranium; therefore, little } \\
\text { decay would have occurred. If the gross } \beta \text { and } \gamma \text { are assumed to be largely }{ }^{90} \mathrm{Sr} \text { and } \\
{ }^{137} \mathrm{Cs} \text {, then decayed value would be about } 70 \% \text { of total released. }\end{array}$} \\
\hline
\end{tabular}


Canyon. This complex included the Chemistry and Metallurgical Research Building where plutonium research was conducted. In September 1953 liquid wastes from the Health Research Laboratory (TA-43) were added to the system. Initially, the TA-3 waste was very dilute, and levels were monitored to determine if treatment was required to maintain the 2week effluent average from TA-45 below 330 disintegrations $/ \mathrm{min} / \ell$, the level adopted as the administrative level for effluent release from TA-45. If treatment was not required to meet the criteria, the TA-3 waste was discharged untreated to Acid Canyon. By December 1953 only about $30 \%$ of the TA-3 waste was released untreated. In 1958, liquid wastes from a new radiochemistry facility (TA-48) were added to the line coming from TA-3. The wastes from this facility included primarily fission products and are reflected in the higher gross beta and gamma content of the TA-45 effluents for 1960 to 1963 shown in Table I.

In July 1963 wastes from TA-3 and TA-48 were redirected to a new Central Waste Treatment Plant (TA-50) located south of Los Alamos Canyon, which is still within the present Los Alamos National Laboratory site. Liquid wastes from TA-43 were redirected to the sanitary sewer because only small quantities of very low-concentration wastes were generated by that time. Subsequently, only liquid wastes from TA-1 were processed at TA-45 until it ceased operation near the end of May, 1964. Some untreated low-level liquid wastes containing fission products from decommissioning the Sigma Building at TA-1 were released until June 1964. After this time, no further effluents were released into Acid Canyon.

Other releases that have some bearing on the interpretation and assessment of the measurements of residual radioactivity in these canyons have been or continue to be made into Pueblo and Los Alamos Canyons. Nonradioactive effluents include those released into Pueblo Canyon from three sanitary waste treatment plants, two of which continue in operation under the management of Los Alamos County. Radioactive effluents are those from the radioactive liquid waste treatment plant still serving TA-21 on the Los Alamos National Laboratory site (Figs. 3 and 4). Effluents from this plant are released into DP Canyon, a small tributary to Los Alamos Canyon. The TA-21 treatment plant started operations in June 1952 to serve the old plutonium processing facility that has now been decontaminated and converted to other uses. The cumulative discharges from that waste treatment plant are summarized in Table II. The plant may treat wastes from new operations at TA-21 in the future, but levels of plutonium and americium are expected to decline. Some residuals from these treated effluents are carried into and down Los Alamos Canyon. Additional information on these effluents and their residuals is presented in Appendix A of Ref. 1. 
TABLE II

\section{RADIOACTIVITY CONTENT OF TREATED EFFLUENTS RELEASED TO DP CANYON FROM TA-21 ${ }^{\mathrm{a}}$}

\begin{tabular}{lc} 
Isotope & $\begin{array}{c}\text { Decay Corrected } \\
\text { Cumulative Activity } \\
\text { (curies) }\end{array}$ \\
\hline${ }^{3} \mathrm{H}$ & 36 \\
${ }^{89,90} \mathrm{Sr}$ & 0.05 \\
${ }^{137} \mathrm{Cs}$ & 0.02 \\
${ }^{235} \mathrm{U}$ & $<0.01$ \\
${ }^{238} \mathrm{Pu}$ & 0.00 \\
${ }^{239} \mathrm{Pu}$ & 0.03 \\
${ }^{241} \mathrm{Am}$ & 0.00 \\
Unidentified gross alpha & 0.02 \\
Unidentified gross beta and gamma & 0.55
\end{tabular}

${ }^{\mathrm{a}}$ Taken from Ref. 1.

beasured data as complied for a summary in the US DOE ODIS. 


\subsubsection{Decontamination and Decommissioning. Decontamination and}

decommissioning of the TA-45 liquid waste treatment plant began in October 1966. All contaminated equipment, plumbing, and removable fixtures were taken to solid radioactive burial areas still located within the current Los Alamos National Laboratory site. The structures for the waste treatment plant (TA-45-2) and the vehicle decontamination facility (TA-45-1) were demolished and all debris removed to the disposal areas. Buried waste lines, manholes, and a significant amount of contaminated soil in the vicinity of the decontamination structure were dug out and the debris transported to the solid radioactive waste disposal area. A total of about 516 dump truck loads of debris were removed during these operations. During the same time, decontamination of portions of Acid Canyon was undertaken. Contaminated tuff was removed from the cliff face where the effluent had flowed. Men using jackhammers and axes were suspended over the cliff edge on ropes with safety harnesses to remove contaminated rock. The debris was loaded into dump trucks at the bottom of the cliff. Contaminated rock, soil, and sediment also were removed from the canyon floor. A total of about 94 dump truck loads of debris were removed from Acid Canyon. The operation was suspended in January 1967 because of cold weather. In the spring of 1967, additional decontamination was undertaken, including removal of other portions of buried waste lines in the TA-45 area, more contaminated rock, and the flow-measuring weir from Acid Canyon. By July 1967 the TA-45 site and Acid Canyon were considered sufficiently free of contamination to allow unrestricted access and removal of signs designating it as a contaminated area. Remaining residual radioactivity at that time was documented to be less than 500 counts/minute of alpha activity (as measured by a portable air-proportional alpha detector) in some generally inaccessible spots and was not considered to be a health hazard.

2.1.2.3 Land Ownership. After initial acquisition or transfer of control of lands to the War Department in the early 1940s and then to the Atomic Energy Commission $(\mathrm{AEC})$ in 1947, a number of other changes in ownership or control have occurred, leading to the present land ownership pattern as it affects the surveyed area. In 1949, the New Mexico State Legislature created the County of Los Alamos, encompassing all of the AECcontrolled lands. In 1961, administrative control of about $15.9 \mathrm{~km}^{2}$ of federal land in Santa Fe County, known as the Otowi Section, was transferred to the AEC from Bandelier National Monument. The portion of Pueblo Canyon between the Los Alamos County line and the confluence with Los Alamos Canyon is included in this area (Fig. 4). 
Pursuant to the Community Disposal Act, the AEC transferred ownership of substantial portions of the townsite to the County of Los Alamos by quitclaim deed on July 1 , 1967. This transfer included the former TA-45 site, Acid Canyon, and the portion of Pueblo Canyon encompassing the channel from Acid Canyon eastward to a point about $1190 \mathrm{~m}$ west of the Los Alamos-Santa Fe County line. The transfer was subject to an easement for continued access to and maintenance of sampling locations and test wells in and adjacent to the channel in Acid and Pueblo Canyons.

From the point about $1190 \mathrm{~m}$ west of the county line to the county line, the Pueblo Canyon channel traverses the Pueblo Canyon Tract, which is under DOE control (Fig. 4). This tract, containing an abandoned emergency landing strip, was declared excess property in 1972 and turned over to the General Services Administration for disposal. It was offered for sale in 1973 but subsequently was withdrawn and returned to control of the AEC, partly because of the unique opportunities it offered for radioecology studies of low levels of plutonium in a natural environment.

At the Los Alamos-Santa Fe County line, the channel crosses into the DOE-controlled Otowi Section. It joins Los Alamos Canyon just east of the junction of State Road 4 and Loop 4. From this point, the Los Alamos Canyon channel continues eastward, roughly paralleling the southern boundary of the Otowi Section. It leaves DOE-controlled property at the eastern boundary of the Otowi Section. From that point to its confluence with the Rio Grande, the Los Alamos Canyon channel is on lands owned by the San Ildefonso Indian Pueblo Reservation (Fig. 4).

\subsection{Need for Action}

2.2.1 Potential Dose Evaluation and Interpretation. The significance of the data on concentrations of radioactivity on soils and sediments, radioactivity on airborne particulates, and external penetrating radiation may be evaluated in terms of the doses that can be received by people exposed to the conditions. The doses can be compared to natural background and appropriate standards or guides for one type of perspective. The doses also can be used to estimate risks or probabilities of health effects to an individual, providing another type of perspective more readily compared to other risks encountered. This section summarizes the analysis of potential doses and risk estimates presented in the radiological survey. ${ }^{1}$ 


\subsubsection{Bases of Dose Estimates and Comparisons. Doses were calculated for}

various pathways that could result in the inhalation or ingestion of radioactivity. The calculations were based on theoretical models or factors from standard references and health physics literature, as detailed in the radiological survey. ${ }^{1}$ The doses are expressed in fractions of rems, where a millirem (mrem) is 1/1000 of a rem and a microrem ( $\mu \mathrm{rem}$ ) is 1/1 000000 of a rem. They are generally expressed as dose rates; that is, the radiation dose received in a particular time interval. The rem is a unit that permits direct comparison of doses from different sources, such as $\mathrm{x}$ rays, gamma rays, and alpha particles. It accounts for the differences in biological effects from the energy absorbed from different radiations and isotope distributions. These doses can be compared to the DOE Radiation Protection Standards, which are expressed as permissible dose or dose commitment in addition to natural background radiation and medical exposures. First year doses represent the dose received during the first year that a given radioactive isotope is ingested or inhaled. Because most of the isotopes of concern in this study are retained in various organs in the body for more than a year, 50-year dose commitments also were calculated. The 50-year dose commitments represent the total dose that would be accumulated in the body or specific critical organs over a 50-year period from ingestion or inhalation during the first year. (Alternatively, the numerical values can be interpreted to represent the annual dose rate during the 50th year given continuous exposure over all 50 years.) The 50-year commitments are always as large or larger than first-year doses. In this summary, only the 50-year commitments are compared to the standards.

Conceptually, this is in agreement with the recommendations of the International Commission on Radiological Protection (ICRP) that for regulatory purposes in effect charge the entire dose commitment against the year in which exposure occurs. ${ }^{3}$ The use of the 50year dose commitment also permits making estimates of risk over a lifetime from the given exposure and simplifies comparisons between different exposure situations.

The dose commitments were calculated using published factors from references currently used in regulation. ${ }^{4,5}$

2.2.1.2 Potential Doses Under Present Conditions. Given present conditions of land use and the residual radioactivity in the affected areas, there are two basic groups (not mutually exclusive) of the public to be considered. One group is the normal residential and working population in Los Alamos County. Measurements of airborne radioactivity and 
external penetrating radiation over many years as part of the Los Alamos National Laboratory routine environmental monitoring program lead to the conclusion that this group is not receiving increments of radiation exposure attributable to the residual contamination.

The second group includes those who occupy the canyon areas for varying periods of time. The occasional users-hikers, picnickers, horseback riders, and others-spend only a small fraction of any given year in the affected areas. The residents of lower Los Alamos Canyon, several households living at Totavi and Otowi on land controlled by the San Ildefonso Pueblo, spend a large fraction of any given year in that one portion of the affected area. Commuters and travelers on State Roads 4 and 502 also occupy lower Los Alamos Canyon for varying periods (see Fig. 4 for general locations).

The potential for exposure is more or less linearly dependent on the amount of time spent in one of the affected areas. For this summary, no attempt was made to develop assumptions of the fractions of time spent by any given person or group in various areas. The maximum likely doses for continuous occupancy throughout a year are tabulated for lower Pueblo/lower Los Alamos Canyons in Table III. These estimates should overstate average annual doses by varying amounts, even in the case of continuous occupancy, because of the assumptions used for the analysis and interpretation of data, as detailed in the radiological survey. ${ }^{1}$ To give two examples: (1) the calculated external penetrating radiation doses are based on the highest averages of soil concentrations in a given segment, even though they persist over only small fractions of the total area and are close to the channels, and (2) actual measurements of airborne radioactivity concentrations in lower Pueblo Canyon suggest that the theoretically estimated resuspension of contaminated soils probably overstates actual average levels by a factor of about 10 .

In canyon areas (Fig. 4), the calculated, external penetrating radiation, whole body dose for 1-year occupancy ranges from less than $0.1 \mathrm{mrem}$ in lower Pueblo Canyon to about $10 \mathrm{mrem}$ in Acid Canyon. (Note that the external penetrating radiation dose is all received in the same year as the exposure occurs, but for risk estimation it also can be considered to be the entire dose commitment from that exposure.) The calculated 50-year dose commitments from inhalation of resuspended dust during 1 year range from less than 0.001 to about 0.05 mrem to the whole body, from about 0.001 to about $2.1 \mathrm{mrem}$ to bone, and from about 0.004 to about $0.11 \mathrm{mrem}$ to lung. None of these are more than about $2 \%$ of the appropriate DOE Radiation Protection Standards (RPS), and most are less than $0.5 \%$. In the particular case of 
Table III

MAXIMUM LIKELY INCREMENTS OF RISK BASED ON EXPOSURE ATTRIBUTABLE TO RESIDUAL RADIOACTIVITY IN LOWER PUEBLO AND LOWER LOS ALAMOS CANYONS ${ }^{26}$

\begin{tabular}{|c|c|c|c|c|c|c|c|}
\hline \multirow[b]{4}{*}{ Location/Exposure } & \multicolumn{3}{|c|}{ Incremental Risk ${ }^{c}$} & \multicolumn{4}{|c|}{ Incremental Dose Commitment } \\
\hline & \multicolumn{3}{|c|}{$\begin{array}{l}\text { (Increased Probability Based } \\
\text { on 50-yr Dose Commitment) }\end{array}$} & \multicolumn{4}{|c|}{ (mrem in 50 yr from Given Exposure) } \\
\hline & \multicolumn{3}{|l|}{ Overall } & \multirow{2}{*}{$\begin{array}{l}\text { External } \\
\text { Whole } \\
\text { Body } \\
\end{array}$} & \multicolumn{3}{|c|}{ Internal Exposure } \\
\hline & $\begin{array}{l}\text { Cancer } \\
\text { Mortality }\end{array}$ & $\begin{array}{l}\text { Bone } \\
\text { Cancer }\end{array}$ & $\begin{array}{l}\text { Lung } \\
\text { Cancer }\end{array}$ & & $\begin{array}{l}\text { Whole } \\
\text { Body }\end{array}$ & Bone & Lung \\
\hline \multicolumn{8}{|l|}{ 1-yr Occupancy } \\
\hline $\begin{array}{l}\text { Lower Pueblo } \\
\text { Canyon }\end{array}$ & $3.6 \times 10^{-8}$ & $2 \times 10^{-9}$ & $7.2 \times 10^{-9}$ & 0.3 & 0.027 & 1.0 & 0.08 \\
\hline $\begin{array}{l}\text { Lower Los Alamos } \\
\text { Canyon } \\
\text { Other Mechanisms } \\
\text { Currently Possible }\end{array}$ & $2.2 \times 10^{-7}$ & $2 \times 10^{-10}$ & $5.4 \times 10^{-9}$ & 1.8 & 0.003 & 0.10 & $\begin{array}{l}\text { Other Mechanisms } \\
\text { Currently Possible }\end{array}$ \\
\hline $\begin{array}{l}\text { Consumption of } \\
\text { Liver from Steer } \\
\text { Graded in Lower } \\
\text { Los Alamos Canyon }\end{array}$ & - & $2 \times 10^{-11}$ & - & - & $<0.001$ & 0.001 & - \\
\hline \multicolumn{8}{|l|}{$\begin{array}{l}\text { Possible with Hypo- } \\
\text { thetical Development }\end{array}$} \\
\hline $\begin{array}{l}\text { Construction Worker } \\
\text { Lower Pueblo Canyon }\end{array}$ & - & $1.8 \times 10^{-7}$ & $5.6 \times 10^{-7}$ & - & - & 89 & 6.2 \\
\hline $\begin{array}{l}\text { Inhalation of Dust by } \\
\text { Home Gardener in } \\
\text { Lower Pueblo Canyon }\end{array}$ & - & $4.6 \times 10^{-8}$ & $1.4 \times 10^{-7}$ & - & - & 23 & 1.6 \\
\hline $\begin{array}{l}\text { Comsumption of } \\
\text { Produce by Home } \\
\text { Gardner in Lower } \\
\text { Pueblo Canyon }\end{array}$ & - & $8.0 \times 10^{-10}$ & - & - & - & 0.4 & - \\
\hline $\begin{array}{l}\text { Natural Background } \\
\text { in }\end{array}$ & & & & & & & \\
\hline 1-yr occupancy & $1.6 \times 10^{-5}$ & - & - & 134 & 24 & - & - \\
\hline 50-yr occupancy & $8 \times 10^{-4}$ & - & - & 6700 & 1200 & - & - \\
\hline $\begin{array}{l}\text { Radiation Protection } \\
\text { Standard }\end{array}$ & - & - & - & 500 & 500 & 1500 & 1500 \\
\hline $\begin{array}{l}\text { Taken from Ref. } 1 \text {. } \\
\text { "All calculations based } \\
\text { 'Risks presented here ha } \\
\text { Reference } 1 \text {. } \\
\text { dProbabilities are expres } \\
\text { multiplication sign (x) } \\
\text { becomes } 9.7 \text { chances ir }\end{array}$ & $\begin{array}{l}\text { conditions. } \\
\text { calculated } u \\
\text { xpoential not } \\
\text { aces" and wr } \\
000 \text {. }\end{array}$ & $\begin{array}{l}\text { sk factors fr } \\
\text { they can be } \\
\text { one (1) foll }\end{array}$ & $\begin{array}{l}\text { erence } 41 . \text { I } \\
\text { led to express } \\
\text { y the number }\end{array}$ & $\begin{array}{l}\text { y differ } \\
\text { chance } \\
\text { s given }\end{array}$ & $\begin{array}{l}\text { from the } \\
\text { g the nu } \\
\text { nent. Fo }\end{array}$ & $\begin{array}{l}\text { resente } \\
\text { value } \\
\text { ple, } 9.7\end{array}$ & f the \\
\hline
\end{tabular}


lower Los Alamos Canyon, where occupancy factors are likely to be highest, the range is from about $0.4 \%$ down to $0.004 \%$ of the standard. The maximum contribution to exposure potential in lower Los Alamos Canyon is that estimated for external exposure, about 1.8 $\mathrm{mrem} / \mathrm{yr}$, or about $1.1 \%$ of natural background.

Raising of beef cattle is another mechanism of exposure that might affect a small number of individuals and was also considered. The estimated dose from this pathway is presented in Table III. Beef cattle are grazed in lower Los Alamos Canyon at times. The likely maximum 50 -year dose commitment is no more than $0.001 \mathrm{mrem}$ to bone or whole body ( $0.0002 \%$ of DOE RPS, $0.0007 \%$ of natural background).

Actual measurements have confirmed the absence of any pathway doses in the Rio Grande attributable to potential incremental contributions of residual radioactivity concentrations above worldwide fallout.

No doses were considered likely from the slight elevations of radioactivity measured in some of the shallow alluvial and perched ground water beneath Pueblo and upper Los Alamos Canyons because they are not now, nor are they likely to be, used. This ground water is limited in extent and is largely recharged by the effluents from the sanitary sewage treatment plants.

Water supply for the residences at Totavi (Fig. 4) is taken from the Los Alamos Municipal system and, therefore, not subject to potential contamination.

One private household near Otowi Bridge (Fig. 4) is on the south bank of lower Los Alamos Canyon, about $600 \mathrm{~m}$ west or upstream from the confluence with the Rio Grande. Its well draws water from the alluvium of lower Los Alamos Canyon. Samples of water from the alluvium appearing as return flow at the mouth of Los Alamos Canyon show no adverse influence from recharge by runoff, based on analyses of 10 chemical parameters and tritium.

The second house near Otowi Bridge is on the west bank of the Rio Grande north, or upstream, from the confluence with lower Los Alamos Canyon. Its well is drilled in the gravels at the edge of the Rio Grande River and draws water recharged from the Rio Grande River. Therefore, it should not be subject to any potential contamination from lower Los Alamos Canyon. 
The only potential dose resulting from residual radioactivity carried by surface water runoff events was that considered as part of the beef cattle pathway analysis. The intermittent runoff normally is quite muddy during peak flows, and any significant human consumption is unlikely.

\subsubsection{Modeling of the Pueblo/Los Alamos Canyon System. Modeling} efforts were undertaken by Battelle's Pacific Northwest Laboratory (PNL) ${ }^{7}$ and Los Alamos National Laboratory (Los Alamos) ${ }^{6}$ to investigate the effects of a 50-year flood in spreading plutonium-contaminated sediment out of (primarily) lower Pueblo Canyon into lower Los Alamos Canyon and into the Rio Grande. The following summarizes the types of models used and the assumptions employed.

PNL.

Three coupled models were used.

(1) Agricultural Runoff Management (ARM). This is an overland, runoff, soil erosion, contaminant transport model. It converts precipitation into runoff through consideration of interception, infiltration, interflow, percolation, and evapotranspiration. Erosion through both sheet and interrill forms are considered. Adsorption and removal of contaminants are simulated using a modified Freudlich adsorption/desorption isotherm algorithm. Contaminants are attenuated by degradation and decay.

Limitations: (a) large quantity of historical data needed to calibrate model, (b) applicable only to small watersheds where channel processes can be considered negligible, generally areas of 2 to $5 \mathrm{~km}^{2}$, (c) erosion as a function of particle size not considered, and (d) effects that winter freeze/thaw cycles could have on soil detachment and overland scouring not considered.

(2) Modified Diffusion Wave with Seepage (MODSEEP). This is an instream hydrodynamic model that allows for seepage into the stream bed (transmission loss). It is a one-dimensional flood-routing code that accounts for lateral inflow and seepage through the channel bed. 
Limitations: (a) Incapable of resolving lateral or vertical variations because of its onedimensionality, and (b) downstream phenomena effects on upstream segments cannot be investigated because of the model's use of an explicit "marching" scheme.

(3) Transient One-Dimensional Degradation and Migration (TODAM). An instream sediment and contaminant transport model, one-dimensional finite element that predicts movement of sediments and radionuclides through use of advection-dispersion equations with decay and source/sink terms transport, deposition, and resuspension of three size fractions of sediment. It assumes that adsorption/desorption mechanisms are completely reversible.

Limitations: (a) Requires extensive data input for calibration, (b) requires extensive computing time even for short-time simulations, and (c) treats adsorption/deposition as completely reversible.

Precipitation Scenario: Assumed rainfall is uniformly distributed in space over the watershed.

Maximum Discharge: Determined using information of flood frequency and maximum discharge published by Los Alamos along with a Log Pearson Type III regression analysis.

General Assumptions:

(1) The bulk of radionuclide activity is associated with larger rather than smaller-sized particles (that is, sand rather than silts and clays).

(2) The activity of the radionuclides is generally confined to the upper $30 \mathrm{~cm}$ of the bed profile. Although the highest ${ }^{239} \mathrm{Pu}$ concentrations appear to be located below the top $2.5 \mathrm{~cm}$, the concentrations were vertically averaged with depth.

(3) The contaminated rock outfall face at the head of Acid Canyon was modeled instead as a channel segment. The $21000 \pm 49000 \mathrm{pCi} / \mathrm{g}$ contamination was assumed to be uniformly distributed throughout the $30 \mathrm{~cm}$ profile as well as by particle size. This "channel segment" was combined with the next channel segment immediately downstream in order to maximize the drainage area into this reach and increase the possibility 
of entraining contaminated sediment. (This is an overestimation as a cleanup has been performed since these data were taken.)

(4) During the modeling simulation, precipitation-generated flow and sediment contributions from upper Los Alamos Canyon, Bayo Canyon, and Guaje Canyon were eliminated. This was done to maximize the amount of contamination that might enter and deposit upon San Ildefonso Indian Pueblo land.

\section{Los Alamos.}

Two models were used.

(1) Hydrologic Component. This uses the Soil Conservation Service method of computing direct runoff from rainfall. The flow is routed through the channel using a onedimensional mass balance approach. The shape of the hydrograph is modified to account for transmission losses, which are approximated using a linear differential equation, and the flow duration and peak discharge equations used in hydrograph construction were developed from data on 15. semiarid watersheds in Arizona. Some empirical relations were employed to account for drainage area, infiltration, and watershed shape. The Manning equation is used for discharge calculations.

(2) Sediment Yield and Contaminant Transport Components. Bed load and suspended sediments are transported piecewise through a channel reach using the sediment transport capacity as calculated with the hydrograph. An enrichment ratio is assumed for the bed load and suspended sediments, weighted, and then a mass balance applied throughout each reach. This is also applied in one dimension only.

Precipitation Scenario: Assumed real average rainfall is distributed according to the ON Atlas 2 formulation.

Maximum Discharge: Estimated maximum 1-hour rainfall was applied to historical records from 1943-1980. A regression equation was applied to obtain snowmelt runoff. A $\log$ normal distribution was fitted to these 38 years of data, and the 50-year event was estimated from the log normal distribution and then routed through the watershed as described. 
General Assumptions:

(1) Ephermeral conditions, annual precipitation less than 20 inches, mean annual runoff about 1 inch, and a watershed about 50 miles in size.

(2) The channel cross section is rectangular and the out-of-bank cross section is trapezoidal.

(3) Normal flow.

(4) The 50-year event is limited to the Pueblo Canyon watershed; there is no flow or sediment contribution from Los Alamos, Bayo or Guaje Canyons.

(5) Sediment transport = sediment transport capacity.

2.2.1.4 Potential Doses Under Future Conditions. Because of the movement of the radionuclide-bearing sediment down the canyon, the doses estimated in the previous section for present use will be changed somewhat. These changes are based on the modeling efforts described in Sec. 2.2.1.3. The study of Lane, Purtyman, and Becker ${ }^{6}$ analyzed sediment movement from typical annual flow and from the 50-year flood. Whelan, Thompson, and Yabusaki ${ }^{7}$ were primarily concerned with the 50-year flood as an application of Multimedia Contaminant Environmental Exposure Assessment Methodology. Results of these studies pertinent for dose calculation are summarized below.

- Typical Annual Flow. Lane, Purtymun, and Becker ${ }^{6}$ estimated future sediment concentrations in the active channel of mid-Pueblo, lower Pueblo, and lower Los Alamos Canyons using historical rainfall data to estimate mean annual runoff and sediment yield. Predicted concentrations, which were found to depend on the initial amount of ${ }^{239,240} \mathrm{Pu}$ discharged into the Acid-Pueblo system, were estimated for assumed initial input values of $750 \mathrm{mCi}, 1500 \mathrm{mCi}$, and $3000 \mathrm{mCi}$. Resulting radionuclide concentrations were predicted to decrease in mid-Pueblo, lower Pueblo and lower Los Alamos Canyons by 50\% every 4 to 5 years as a result of erosion. The radionuclide concentrations in the bank and inactive channel areas were not treated in this analysis, since these areas are not expected to be greatly affected by annual flow. These authors estimated the annual discharge into the Rio Grande caused by sediment transport during $1971-1980$ to range from 3.5 to $10.8 \mathrm{mCi}$ of ${ }^{239,240} \mathrm{Pu}$. 
Annual redistribution of radioactivity by erosion would result in lower predicted doses for the beef cattle food pathway (for a cow grazing in lower Los Alamos Canyon) because of the dilution of present concentrations with clean sediment. If the assumption is made that after 5 years the ${ }^{239,240} \mathrm{Pu}$ concentration in the water will be reduced by $50 \%$ and ${ }^{239,240} \mathrm{Pu}$ in vegetation will remain the same as before, the predicted maximum 50-year dose commitment for bone from consumption of beef liver would be reduced from 0.00013 mrem to 0.00008 mrem, $5 \times 10^{-6} \%$ of the RPS for members of the public. Doses from other scenarios, such as construction of houses and gardening in lower Pueblo Canyon, would not be greatly affected because these doses depend primarily on concentrations in the inactive channel and banks.

Doses to downstream users resulting from the predicted discharge of sediment into the Rio Grande from Los Alamos Canyon were calculated using a procedure recommended by the US Nuclear Regulatory Commission (Appendix D). The annual discharge of ${ }^{239,240} \mathrm{Pu}$ was taken to range from 3.5 to $10.8 \mathrm{mCi} .{ }^{6}$ Estimated discharges of ${ }^{238} \mathrm{Pu},{ }^{241} \mathrm{Pu},{ }^{241} \mathrm{Am},{ }^{234} \mathrm{U},{ }^{137} \mathrm{Cs}$ and ${ }^{90} \mathrm{Sr}$ were based on the ${ }^{239,240} \mathrm{Pu}$ discharge and the ratio of each radionuclide sediment concentration to the ${ }^{239,240} \mathrm{Pu}$ sediment concentration in lower Los Alamos Canyon. These estimated annual discharges from Los Alamos Canyon at Otowi are summarized in Table IVa and compared with a typical radionuclide flow in the Rio Grande upstream from Otowi resulting from background concentrations of these radionuclides.

As can be seen from Table IVa, modeled annual discharges to the Rio Grande at Otowi from Los Alamos Canyon are, with the exception of the plutonium isotopes discussed below, small fractions of estimated amounts of each radionuclide that the Rio Grande carries past Otowi each year. This annual flux of radionuclides at Otowi, which is estimated with sampling data taken by the Laboratory's Environmental Surveillance Group, results from sediment transport of naturally occurring radioactivity and material deposited by worldwide fallout.

The discharges of both Pu-238 and Pu-239/240 from Los Alamos Canyon have been estimated by Lane, Purtymun, and Becker ${ }^{6}$ to be roughly the same magnitude as the annual flux of plutonium in the Rio Grande as a result of worldwide fallout. This is especially true for the 3000-mCi initial input case. Consequently, concentrations of Pu-238 and Pu-239/240 in sediments downstream of the Rio Grande/Los Alamos Canyon confluence would be expected to be as much as a factor of two higher than those in sediments upstream. No such increase has been observed, however, after several decades of sediment sampling at these 
TABLE IVa

ESTIMATED AVERAGE RADIONUCLIDE DISCHARGES FROM LOS ALAMOS
CANYON AND BACKGROUND RADIONUCLIDE FLUX IN THE RIO GRANDE

\begin{tabular}{|c|c|c|c|c|}
\hline \multirow[b]{2}{*}{ Radionuclide } & \multicolumn{3}{|c|}{$\begin{array}{l}\text { Los Alamos Canyons } \\
\text { (curies/year) }^{\mathrm{a}}\end{array}$} & \multirow{2}{*}{$\begin{array}{l}\text { Typical Annual Background } \\
\text { Radionuclide Flux in Rio } \\
\text { Grande Upstream at Otowi } \\
\text { (curies/year) }^{\mathrm{b}}\end{array}$} \\
\hline & $\begin{array}{l}\text { Assumed Ini } \\
\quad 750 \mathrm{mCi}\end{array}$ & $\begin{array}{l}\text { nput into } A \\
1500 \mathrm{mCi}\end{array}$ & $\begin{array}{l}\text { 1eblo Canyon } \\
3000 \mathrm{mCi}\end{array}$ & \\
\hline${ }^{90} \mathrm{Sr}$ & 0.00079 & 0.0013 & 0.0025 & 2.3 \\
\hline${ }^{137} \mathrm{Cs}$ & 0.0010 & 0.0017 & 0.0032 & 33 \\
\hline${ }^{234} \mathrm{U}$ & 0.170 & 0.29 & 0.53 & 3.3 \\
\hline${ }^{238} \mathrm{Pu}$ & 0.00010 & 0.00018 & 0.00032 & 0.00049 \\
\hline${ }^{239,240} \mathrm{Pu}$ & 0.0035 & 0.0059 & 0.011 & 0.011 \\
\hline${ }^{241} \mathrm{Pu}$ & 0.0026 & 0.0045 & 0.0082 & 0.050 \\
\hline${ }^{241} \mathrm{Am}$ & 0.0073 & 0.0012 & 0.0023 & 0.0036 \\
\hline
\end{tabular}

${ }^{2}$ Estimated from Ref. 6.

${ }^{b}$ Estimated from sediment and water samples taken in $1979-1981^{18,36}$, and sediment- and water-flow rates at Otowi during $1979 .{ }^{40}$ 
locations (see, for example, reference 18). The model, therefore, could be over-predicting plutonium levels in sediment in the Rio Grande. Calculating dose to downstream users of the Rio Grande utilizing the results of this model would add an additional element of conservation to the dose assessment as these doses also would tend to be over-predictions.

Dose pathways considered were use of the Rio Grande as a source of drinking water, consumption of fish, consumption of produce irrigated with Rio Grande water, consumption of meat from cattle watered in the Rio Grande and grazed on pasture irrigated with water from the Rio Grande, and shoreline exposure to external radiation. The maximum 50-year dose commitment was estimated to range from 1.5 to $4.7 \mathrm{mrem} / \mathrm{year}$ to bone, which is less than $2 \%$ of the RPS. These doses, which were estimated using the 1971-1980 annual average discharge to the Rio Grande, will decrease exponentially as the radionuclide concentrations decrease exponentially in soils and sediments in the canyon system.

The doses calculated here can be compared with those resulting from typical radionuclide concentrations in the Rio Grande caused by natural background or worldwide fallout. Over $97 \%$ of the calculated bone dose from typical annual discharges from Los Alamos Canyon is caused by ingestion of ${ }^{234} \mathrm{U}$ (77\% of the dose) and ${ }^{90} \mathrm{Sr}(21 \%$ of the dose). Doses resulting from plutonium isotopes ${ }^{241} \mathrm{Am}$ and ${ }^{137} \mathrm{Cs}$ comprise the remaining $2 \%$. The maximum estimated typical annual discharge of $0.53 \mathrm{Ci}$ of ${ }^{234} \mathrm{U}$ from Los Alamos Canyon into the Rio Grande is only $16 \%$ of the approximately $3.3 \mathrm{Ci}$ of ${ }^{234} \mathrm{U}$ already in the Rio Grande from natural background that is transported past the confluence with Los Alamos Canyon each year. The corresponding percentage for ${ }^{90} \mathrm{Sr}$ is $0.1 \%$, where the ${ }^{90} \mathrm{Sr}$ already in the Rio Grande is from worldwide fallout. Because the amounts of these radionuclides discharged from Los Alamos Canyon are only small fractions of the flux of each radionuclide already in the Rio Grande from natural sources and worldwide fallout, the contribution of Acid/Pueblo/Los Alamos Canyon discharges to the dose to downstream users of the Rio Grande is only a small fraction of the dose from natural background and worldwide fallout.

The finding is in agreement with foodstuff sampling data collected annually and published in the annual surveillance reports for the Los Alamos National Laboratory. Concentrations of ${ }^{238} \mathrm{Pu},{ }^{239,240} \mathrm{Pu},{ }^{90} \mathrm{Sr},{ }^{137} \mathrm{Cs}$ and total uranium are routinely measured in fish and produce samples collected both at Cochiti Lake and at locations upstream from Laboratory discharge points. ${ }^{18}$ No radionuclide concentration in samples from Cochiti Lake has been shown to be consistently above the corresponding background levels measured in 
samples from the upstream locations. Occasionally, a radionuclide concentration may be slightly higher statistically at Cochiti Lake than at background sites for a given foodstuff, but no trend has ever emerged and that radionuclide concentration is indistinguishable from background the following year. This indicates that the contribution, if any, to the radionuclide concentrations at Cochiti Lake from discharges to the Rio Grande from Los Alamos are so small that they are very difficult to distinguish from background.

- 50-Year Flood. In addition to redistribution of radioactivity from normal flow, the redistribution resulting from a major flood was analyzed. The 50-year flood has the potential to overflow existing banks and erode material from the inactive channel and bank areas. Both Lane, Purtyman, and Becker ${ }^{6}$ and Whalan, Thompson, and Yabusaki ${ }^{7}$ considered the impacts of the 5-year flood, although with different boundary parameters.

Lane, Purtyman, and Becker ${ }^{6}$ found that the 50-year flood would result in net erosion in Pueblo Canyon and net deposition in lower Los Alamos Canyon. Plutonium concentrations in Pueblo Canyon were expected to decrease by $60 \%$ for the active channel and $4 \%$ for the out-of-bank areas. The concentrations in lower Los Alamos Canyon were predicted to increase by $30 \%$ to $60 \%$ in the active channel and $1 \%$ to $2 \%$ in the out-of-back areas. The ${ }^{239,240} \mathrm{Pu}$ transport past the confluence of Los Alamos and Guaje Canyons was estimated to range from 15 to $50 \mathrm{mCi}$. The ${ }^{239,240} \mathrm{Pu}$ discharge to the Rio Grande was calculated to range from 11 to $43 \mathrm{mCi}$ (Table IVb).

Whelan, Thompson, and Yabusaki ${ }^{7}$ also considered the ${ }^{239,240} \mathrm{Pu}$ redistribution resulting from a 50-year flood in Acid and Pueblo Canyons. Their analysis extended as far as the confluence of Los Alamos and Bayo Canyons. Their prediction for the amount of ${ }^{239,240} \mathrm{Pu}$ carried past the Bayo Canyon confluence was obtained by integration of their curving giving ${ }^{239,240} \mathrm{Pu}$ flux versus time. This integration indicates that approximately $2.1 \mathrm{mCi}$ of ${ }^{239,240} \mathrm{Pu}$ would be transported beyond the Bayo Canyon confluence.

Given the uncertainties in modeling and the differences in approach of the two studies, the results of the two studies are in good agreement.

Maximum doses resulting from the redistribution of ${ }^{239,240} \mathrm{Pu}$ as a result of the 5-year flood were calculated using the same procedure as before, ${ }^{2}$ but modified for a single rather 
TABLE IVb

\section{RADIONUCLIDE DISCHARGES FROM LOS ALAMOS CANYON (50-year flood event)}

\begin{tabular}{|c|c|c|c|}
\hline \multirow[b]{3}{*}{ Radionuclide } & \multicolumn{3}{|c|}{$\begin{array}{l}\text { Discharge from 50-Year Flood } \\
\text { (curies/year) }\end{array}$} \\
\hline & \multicolumn{3}{|c|}{ Initial Input into Acid Pueblo } \\
\hline & $740 \mathrm{mCi}$ & $1500 \mathrm{mCi}$ & $3000 \mathrm{mCi}$ \\
\hline${ }^{90} \mathrm{Sr}$ & 0.0025 & 0.0054 & 0.0097 \\
\hline${ }^{137} \mathrm{Cs}$ & 0.0097 & 0.021 & 0.037 \\
\hline${ }^{234} \mathrm{U}$ & 0.96 & 2.1 & 3.7 \\
\hline${ }^{238} \mathrm{U}$ & 0.00033 & 0.00071 & 0.0013 \\
\hline${ }^{239,240} \mathrm{Pu}$ & 0.011 & 0.024 & 0.043 \\
\hline${ }^{241} \mathrm{Pu}$ & 0.0084 & 0.018 & 0.033 \\
\hline${ }^{241} \mathrm{Am}$ & 0.0023 & 0.0050 & 0.0090 \\
\hline
\end{tabular}


than continuous release, and with the estimated new radionuclide soil and sediment concentrations. Based on the modeling results, ${ }^{239,240} \mathrm{Pu}$ concentrations were assumed to increase by $60 \%$ in the active channel and by $2 \%$ in the out-of-bank areas in lower Los Alamos Canyon, and from 11 to $43 \mathrm{mCi}$ of ${ }^{239,240} \mathrm{Pu}$ were assumed to discharge into the Rio Grande. Concentrations and discharge rates for ${ }^{90} \mathrm{Sr},{ }^{137} \mathrm{Cs},{ }^{234} \mathrm{U},{ }^{238} \mathrm{Pu},{ }^{241} \mathrm{Pu}$ and ${ }^{241} \mathrm{Am}$ were obtained by scaling to the predicted ${ }^{239,240} \mathrm{Pu}$ values (Table IVb). The ratio of the individual radionuclide concentration to the ${ }^{239,240} \mathrm{Pu}$ concentration was used.

The maximum 50-year dose commitment was conservatively estimated to range from 4.2 to 16 mrem to the bone, or 0.3 to $1 \%$ of the RPS for members of the public, depending on the value of the initial plutonium input assumed. This dose was estimated for downstream users of the Rio Grande if several unlikely circumstances that would maximize the dose were to occur. These circumstances include an individual's obtaining his entire yearly intake of vegetables and fruit from produce irrigated by water from the Rio Grande immediately after the flood event.

\subsubsection{Potential Doses Associated With Cleanup. Radiation doses resulting} from removal of residual radioactivity from the canyon system were evaluated for cleanup workers, truck drivers hauling the material to the waste disposal site, and the general public. Both routine and accident situations were considered. Resulting doses were then compared with the appropriate RPS. A discussion of the dose calculation procedures and assumptions is presented in Appendix D. Doses are summarized in Table V.

The calculated doses were used as the basis for estimating health risks associated with remedial action at the former plant site. The associated risks are discussed in Sec. 2.2.2.

Removing all contaminated soil in Acid, middle Pueblo, lower Pueblo, and lower Los Alamos Canyon would require approximately 1460 hours at the job site for a 4-man crew.* The volume of soil to be excavated and transported to the radioactive waste disposal site is estimated to be of ${ }^{239} \mathrm{Pu}$ contained in this soil is $631 \mathrm{mCi}$, giving concentration of 2.6 $\mathrm{pCi} / \mathrm{gram}$.

*Estimate obtained from a local engineering firm. 


\section{TABLE V}

\section{POTENTIAL DOSES ASSOCIATED WITH CLEANUP}

Incremental Risk

(Increased Probability of Morality

Based on 5-Year Dose Commitment)

\begin{tabular}{lccc}
\cline { 2 - 4 } $\begin{array}{l}\text { Clean-up } \\
\text { of Entire Site }\end{array}$ & $\begin{array}{c}\text { Cancer Mortality } \\
\text { from External Whole } \\
\text { Body Radiation }\end{array}$ & \multicolumn{2}{c}{ Risk from Internal Radiation } \\
\cline { 3 - 4 } & $2 \times 10^{-8}$ & $\begin{array}{c}\text { Bone } \\
\text { Cancer }\end{array}$ & $\begin{array}{c}\text { Lung } \\
\text { Cancer }\end{array}$ \\
\hline Workers & $9 \times 10^{-9}$ & $8 \times 10^{-7}$ & $4 \times 10^{-6}$ \\
Truck Drivers & $5 \times 10^{-8}$ & $4 \times 10^{-7}$ \\
$\begin{array}{l}\text { Public } \\
\text { Routine }\end{array}$ & $5 \times 10^{-9}$ & $<1 \times 10^{-9}$ & $7 \times 10^{-9}$ \\
Accident & $<1 \times 10^{-9}$ & $<1 \times 10^{-9}$ & $<1 \times 10^{-9}$
\end{tabular}

\begin{tabular}{cccc}
\multicolumn{4}{c}{ Incremental Dose } \\
\hline \multirow{4}{*}{$\begin{array}{c}\text { Internal Exposure } \\
\text { External }\end{array}$ Whole Body } & Whole Body & Bone & Lung \\
\cline { 2 - 4 } 0.13 & 11 & 390 & 44 \\
0.073 & 0.80 & 29 & 3.9 \\
& & & \\
0.042 & $<0.01$ & 0.13 & 0.078 \\
$<0.01$ & $<0.01$ & 0.17 & $<0.01$
\end{tabular}

Construction of

Sediment Trap

Workers
Truck Drivers
Public
$\quad$ Routine
Accident

$$
\begin{aligned}
& <1 \times 10^{-9} \\
& <1 \times 10^{-9} \\
& <1 \times 10^{-9} \\
& <1 \times 10^{-9}
\end{aligned}
$$$$
2 \times 10^{-7}
$$$$
1 \times 10^{-8}
$$$$
6 \times 10^{-7}
$$$$
<1 \times 10^{-9}
$$$$
5 \times 10^{-8}
$$

$<1 \times 10^{-9}$

$<1 \times 10^{-9}$

\section{$<0.01$}

$<0.01$

$<0.01$

$<0.01$

$$
\begin{aligned}
& <0.01 \\
& <0.01
\end{aligned}
$$

$0.15-0.48$

$0.27-1.1$

1.5-4.7

4.2-16

---

5-Year Flood ${ }^{2}$

$-\cdot$

$\begin{array}{ll}-- & - \\ -- & - \\ -- & -\end{array}$

$--$

3000
5000
$500 / \mathrm{yr}$

5000
$500 / y r$

$--$

${ }^{a}$ The range of risk and dose estimates is because of the uncertainty in the initial plutonium input into the Canyon System. 
Radiation doses were calculated for cleaning each canyon section individually, then summed to give the total dose. In performing these calculations, conservative assumptions were made that increased the calculated dose for this worst-case estimate. The calculation used a dust loading of $5 \mathrm{mg}$ of respirable material per cubic meter of air, which is the threshold limit value for dust loading as set by the American Conference of Governmental Industrial Hygienists. The actual dust loading at the work site is expected to be significantly less than this limit. Control measures, such as soaking the contaminated soil with water, would be taken in any situation where there is a potential for resuspension of contaminated soil. These control measures were found to be very effective in past operations in reducing airborne radioactivity. ${ }^{8}$ Doses reported here are, therefore, likely to be overestimates of the actual dose.

Any exposures incurred by cleanup workers and drivers of trucks would be monitored and maintained as low as reasonably achievable by standard health physics methods. Air samples would be taken at the work site to evaluate the potential for inhalation exposure. Workers would be issued personal dosimeters to measure exposure to external radiation. Bioassays would be routinely performed as an added measure to detect the possibility of internal radiation exposure.

- Doses to Cleanup Workers. Workers at the cleanup site would be exposed to increased dust levels caused by operation of heavy machinery used to remove contaminated soil. Because this dust would contain above-background levels of the radionuclides found in the soil, some radiation dose potentially would be incurred by the workers. In addition to this inhalation exposure, there would be exposure to above-background external radiation (maximum level is $0.7 \%$ of background) from gamma-emitting radionuclides in the soil.

Doses to workers from inhalation and external radiation exposures were calculated using procedures in Appendix D. The organ receiving the dose that is the highest fraction of its RPS is bone. The 50-year dose commitment to bone is $390 \mathrm{mrem}$, which is $1.3 \%$ of the RPS for occupational exposure for a year. The highest dose estimated for a calendar quarter is $256 \mathrm{mrem}$ to the bone, or $2.6 \%$ of the RPS for occupational exposure for a quarter. Over $99 \%$ of this dose is caused from inhalation of dust containing above-background concentrations of radioactive material. Doses from exposure to external radiation account for the remainder of this dose. 
- Doses to Truck Drivers. Truck drivers would spend an estimated $8 \%$ of their time at the cleanup site, where they would be exposed to the same airborne radioactivity and external radiation levels as the cleanup workers. In addition, while driving a truckload of contaminated soil to the radioactive waste disposal site, they would be exposed to external radiation from gamma-emitting radionuclides in the soil.

As with the cleanup workers, bone is the organ receiving a dose that is the highest fraction of its RPS. The 50-year dose commitment to bone is $29 \mathrm{mrem}, 0.1 \%$ of the RPS for occupational exposure for a year.

\section{- Doses to the General Public}

Routine Operations. The principle exposure mechanism for the general public would be through inhalation of dust generated by the cleanup activities. Doses were estimated using meteorological modeling and dust release rates for mechanical resuspension.

The 50-year dose commitment to the bone as a result of cleanup was estimated to be $0.13 \mathrm{mrem}$, which is $0.01 \%$ of the RPS for members of the public. All doses to other organs are smaller fractions of their respective RPS.

No significant doses are expected to result from the routine transportation of soil containing residual radioactivity to the radioactive waste disposal site. Truck loads will have covers to prevent any release of material during transportation. This will effectively eliminate the potential for inhalation of material blowing off the trucks. Doses from external radiation to those individuals momentarily near the truck are estimated to be less than $0.042 \mathrm{mrem}$, which is $0.01 \%$ of the RPS.

- Accidents. Radiation doses to the general public as a result of a truck accident resulting in a spill of soil containing residual radioactivity in a populated area also were evaluated. If such an accident were to occur, measures would be taken immediately to control the dusting from the soil. These would include keeping the soil covered before removal and wet during removal. The soil would be removed as quickly as possible. The maximum 50year dose to the general public from a spill of soil containing radioactive concentrations typical of the radioactive material handled during this project is $0.17 \mathrm{mrem}$ to the bone, or $0.01 \%$ of the RPS for members of the public (Appendix D). 


\subsubsection{Potential Doses Associated with the Construction of a Sediment Trap.}

Potential radiation doses would result from inhalation of soil resuspended by construction activity, particularly use of heavy machinery, in building the sediment trap. Because of the low levels of gamma-emitting radionuclides, doses caused by exposure to external radiation are expected to be much less than doses from inhalation.

The sediment trap would be constructed in lower Pueblo Canyon, an area with intermediate soil concentrations of most radionuclides compared to the concentrations in Acid, middle Pueblo, and lower Los Alamos Canyons. The area of the proposed sediment trap was estimated to be $58000 \mathrm{~m}^{2}$. The top $30 \mathrm{~cm}$ of soil in this area were assumed to have radionuclide concentrations typical of lower Pueblo Canyon, given in Table D-I (Appendix D).

Personnel constructing the sediment trap would be considered as radiation workers. Radiation protection measures invoked for handling of contaminated soil removed during the construction phases would be similar to those for radiation workers. This would include air sampling, issuance of personal dosimeters, bioassay, and source term mitigation, such as wetting the soil.

Since the removal of the contaminated top layer of soil would be accomplished during a calendar quarter, the doses to workers are compared to the RPS for doses received during a quarter.

- Doses to Construction Workers. The 50-year dose commitment to bone is estimated to be $83 \mathrm{mrem}$, or $0.8 \%$ of the Radiation Protection Standard for occupational exposure during a quarter. Doses to other organs are smaller fractions of their respective RPS. Over $99 \%$ of the construction dose is caused from inhalation of resuspended soil, and the remainder is from exposure to external radiation.

- Doses to Truck Drivers. The disposal area for soil excavated from the sediment trap in lower Pueblo Canyon has not yet been identified. Consequently, the exposure times for the truck drivers have not been defined.

However, to provide a representative estimate of the doses to these individuals, the same transport times as used in the option of total cleanup (Sec. 2.2.1.5) were used. This 
assumes that the contaminated soil would be taken to the Laboratory waste disposal area at TA-54, even though that area does not have sufficient capacity to keep the large volume of soil that would be excavated.

Truck drivers are expected to receive a 50-year dose commitment of less than 6.3 mrem to the bone, or $0.06 \%$ of the RPS for bone for a calendar quarter. This dose would be incurred while at the work site. The radiation dose received while transporting soil to the disposal site is estimated to be less than $0.01 \mathrm{mrem}$ to the whole body (less than $0.001 \%$ of the RPS), which would be from exposure to external radiation.

- Doses to Members of the Public. No member of the public is expected to receive more than 0.06 mrem to any organ ( $0.004 \%$ of the RPS) as a result of the construction of the sediment trap. The construction site is over $3 \mathrm{~km}$ from the nearest resident. Atmospheric dispersion would dilute radionuclide levels from resuspended dust to negligible levels at that distance. Motorists passing by the construction site would occasionally be exposed to slightly increased concentrations of airborne radioactivity. However, dose calculations based on a motorist passing by the site four times a day at $65 \mathrm{~km} / \mathrm{h}$ for the duration of the entire project indicate that under credible worst case assumptions, the 50-year dose commitment to bone would be less than $0.06 \mathrm{mrem}(0.003 \%$ of the RPS). Doses to other organs would be appreciably less than the bone dose.

Transportation of the contaminated soil to the disposal site is expected to result in less than 0.01 mrem to any organ (less than $0.001 \%$ of the RPS for whole body radiation) from external radiation from the low concentrations of the gamma-emitting radionuclides in the soil.

- Accidents. An accident scenario, similar to the scenario analyzed for complete cleanup (Sec. 2.2.1.4), was evaluated. In this scenario, a truck transporting contaminated soil to the disposal site overturns. The soil is uncovered and available for wind resuspension for 3 hours before it is removed. Soil removal is performed during the last half hour. A conservative assumption is that the soil has radionuclide concentrations equal to the average concentrations for the bank in lower Pueblo Canyon, which has the highest concentrations of all radionuclides (except for ${ }^{234} \mathrm{U}$ ) of all the sampled strata.

The maximum 50-year dose commitment to a member of the public as a result of an accident was estimated to be $0.01 \mathrm{mrem}$ to the bone, which is $0.001 \%$ of the RPS for a 
member of the public. Doses to all other organs are smaller percentages of their respective RPS.

\subsubsection{Health Risks from Pueblo/Los Alamos Residual Radioactivity}

2.2.2.1 Risks from Existing Conditions. Estimates of radiological risks are presented in Table III. Multiplying an estimated dose and the appropriate risk factor yields an estimate of the probability of injury to an individual as a result of that exposure. The risk factors used are ${ }^{41}$

For uniform whole-body dose

Cancer mortality $120 \times 10^{-6}$ per rem whole body

For specific organ doses

$\begin{array}{ll}\text { Lung cancer } & 90 \times 10^{-6} \text { per rem to lung } \\ \text { Bone cancer } & 2 \times 10^{-6} \text { per rem to bone }\end{array}$

As an example, a whole-body dose of $10 \mathrm{mrem} / \mathrm{yr}\left(1 \times 10^{-2} \mathrm{rem} / \mathrm{yr}\right)$ is estimated to add a risk of cancer mortality to the exposed individual of $1.2 \times 10^{-2} / \mathrm{yr}$ of exposure, or 1.2 chances in $1000000 / y r$ of exposure.

Natural background radiation for people in the Los Alamos area consists of the external penetrating dose from cosmic and terrestrial sources, cosmic neutron radiation, and self-irradiation from natural isotopes in the body. The several year average for external penetrating radiation measured by a group of 12 perimeter stations, located mainly in the Los Alamos townsite, is about $117 \mathrm{mrem} / \mathrm{yr}$. Cosmic neutrons contribute about $11 \mathrm{mrem} / \mathrm{yr}$, and average self-irradiation, largely from natural radioactive potassium $\left({ }^{40} \mathrm{~K}\right)$, is about $24 \mathrm{mrem} / \mathrm{yr}$. These give a combined dose of about $158 \mathrm{mrem} / \mathrm{yr}$. Because of variations in the terrestrial component with location and time of year, this value is probably valid to about $\pm 25 \%$ for most of the Los Alamos population. For purposes of comparison, a rounded value of $150 \mathrm{mrem} / \mathrm{yr}$ is used as typical natural background in the area. Using the above risk factors, this can be interpreted to represent a contribution to the risk of cancer mortality of $1.8 \times 10^{-5}$ (18 chances in 1000000 ) for each year of exposure, or $9 \times 10^{-4}$ ( 9 chances in 10000 ) in $50 \mathrm{yr}$ of exposure to natural background radiation. As perspective, estimates of the overall US population lifetime risk of mortality from cancer induced by all causes is currently about 0.2 ( 2 chances in $10)^{9}$ 
Another context for judging the significance of risks associated with exposure to radiation, whether from natural background or other sources, is comparison with risks from activities or hazards encountered in routine experience. Table VI presents a sampling of risks for activities that may result in early mortality and annual risks of death from accidents or natural phenomena. The largest incremental risks from exposure to the residual radioactivity are about the same as the incremental risk of a 1000-mile automobile trip; most are smaller than the annual risk of death from lightning. Radiation from various natural external and internal sources results in exactly the same types of interactions with body tissues as those from so-called "manmade" radioactivity. Thus, the risks from a given dose are the same, regardless of the source.

2.2.2.2 Risks from Cleanup. Dose estimates from Sec. 2.2.1.5 and risk factors presented in Sec. 2.2.2.1 were used to calculate the incremental risk of cancer mortality resulting from radiation doses received during cleanup operations. The estimated risks are presented in Table V. The risks are calculated for cleanup workers, drivers, and the general public.

As can be seen in the table, the largest risk of injury from radiation would occur to the cleanup workers. The incremental cancer mortality from lung cancer is $4 \times 10^{-6}$ ( 1 chance in 250 000). For the worker, the total incremental risk of dying from any type of cancer resulting from both internal and external above-background radiation doses is $4.8 \times 10^{-6}$ (one chance in 210000 ). All other risks of cancer mortality to the drivers and the general public would be lower.

The risk estimates in Table V can be compared to those incurred from exposure to natural background radiation, as discussed in Sec. 2.2.2.1. The lifetime risk of cancer mortality from a 1-yr exposure to background radiation is $1.8 \times 10^{-5}$ (18 chances in 1000 000). During $1460 \mathrm{~h}$ of cleanup work, the lifetime risk of cancer from natural background radiation is $3.0 \times 10^{-6}$ ( 1 chance in 330000 ).

2.2.2.3 Risks from Construction of the Sediment Trap. Risks were calculated using the dose estimates from Sec. 2.2.1.6 and the risk factors from Sec. 2.2.2.1. The doses and associated risks are shown in Table V. 
TABLE VI

RISK COMPARISON DATA ${ }^{\mathrm{a}}$

Individual Increased Chance of Death

Caused by Selected Activities ${ }^{2}$

\begin{tabular}{llc}
\multicolumn{1}{c}{ Activity } & & $\begin{array}{c}\text { Increase in Chance } \\
\text { of Death }\end{array}$ \\
\hline Smoking 1 pack of cigarettes (cancer, heart disease) & & $1.5 \times 10^{-6}$ \\
Drinking $1 / 2$ liter of wine (cirrhosis of the liver) & $1 \times 10^{-6}$ \\
Chest x ray in good hospital (cancer) & $1 \times 10^{-6}$ \\
Traveling 10 miles by bicycle (accident) & & $1 \times 10^{-6}$ \\
Traveling 1000 miles by car (accident) & $3 \times 10^{-6}$ \\
Traveling 3000 miles by jet (accident, cancer) & & $3.5 \times 10^{-6}$ \\
Eating 10 tablespoons of peanut butter (liver cancer) & & $2 \times 10^{-7}$ \\
Eating 10 charcoal broiled steaks (cancer) & $1 \times 10^{-7}$
\end{tabular}

US Average Individual risk of Death in one Year as a Result of Selected Causes

\begin{tabular}{lll} 
& Cause & \\
\cline { 1 - 2 } Motor Vehicle Accident & & Annal Risk of Death \\
Accidental Fall & & $1 \times 10^{-4}$ \\
Fires & $4 \times 10^{-4}$ \\
Drowning & $3 \times 10^{-5}$ \\
Air Travel & $1 \times 10^{-5}$ \\
Electrocution & $6 \times 10^{-6}$ \\
Lightning & $5 \times 10^{-7}$ \\
Tornadoes & $4 \times 10^{-7}$
\end{tabular}

US Population Lifetime Cancer Risk

Contracting Cancer from All Causes

0.25

Mortality from Cancer

0.20

${ }^{\mathrm{a}}$ Taken from Ref. 1. 
The highest estimated risk occurs to construction workers excavating the contaminated soil for the sediment trap. The total lifetime risk of mortality from all types of cancer that may have resulted from these incremental and external radiation exposures is $8 \mathrm{x}$ $10^{-7}$ (one chance in 1250000 ). Risks to both truck drivers and members of the public are at least one order of magnitude lower (Table V). These risk estimates can be compared with the lifetime risk of cancer mortality resulting from one year's exposure to natural background radiation of $1.8 \times 10^{-5}$ (18 chances in 1000000$)$. The risk from natural background radiation incurred by the construction workers during the estimated $164 \mathrm{~h}$ needed to excavate the contaminated soil in lower Pueblo Canyon is $3.4 \times 10^{-7}$ (one chance in 3000000 ).

2.2.2.4 Risks Under the No-Action Alternative. Risks under this alternative are similar to those given in Section 2.2.2.1. Future risks for the scenarios evaluated in that section should be smaller because of the decrease in radionuclide concentrations with time.

Risks to downstream users of the Rio Grande have also been evaluated under this alternative. The risks for an annual discharge and for the discharge resulting from a 50-year flood event were considered. The highest risk was from the 50-year flood. Using conservative assumptions (that tended to maximize the dose) the risk of bone cancer was estimated to range from $8 \times 10^{-9}$ to $32 \times 10^{-9}$ ( 8 to 32 chances in 1000000000 ). Risks of other cancers would be much less than the risk of bone cancer. These risks are less than $0.2 \%$ of the cancer mortality risk of $1.8 \times 10^{-6}$ incurred annually from background radiation.

2.2.3 Criteria Upon Which Cleanup Action is Based. The proposed criteria for determination of cleanup action are shown in Table VII. These data are taken from Refs. 9, 10, and 11. The basis for these criteria is the determination of the soil level for each radioisotope that would result in an annual dose to any organ greater than $500 \mathrm{mrem}$. This determination is made by analyzing various pathways of exposure and then calculating the proposed criteria based on the worst exposure. The derivation of the criteria also assumes that the residual radioactivity is near the soil surface. The $500 \mathrm{mrem} / \mathrm{yr}$ dose for any organ is based on recommendations of the National Council on Radiation Protection and Measurements for dose limits for the general public. ${ }^{12}$ 


\section{TABLE VII}

PROPOSED CRITERIA FOR SOIL CLEANUP ACTION

\begin{tabular}{lc} 
Nuclide & Concentration $(\mathrm{pCi} / \mathrm{g})$ \\
\cline { 2 - 2 } $\mathrm{Am}$ & 20 \\
${ }^{239} \mathrm{Pu}$ & 100 \\
${ }^{238} \mathrm{Pu}$ & 100 \\
${ }^{238} \mathrm{U}^{240} \mathrm{U}$ & 40 \\
${ }^{232} \mathrm{Th}$ & 20 \\
${ }^{230} \mathrm{Th}$ & 280 \\
${ }^{228} \mathrm{Th}$ & 50 \\
${ }^{137} \mathrm{Cs}$ & 80 \\
${ }^{90} \mathrm{Sr}$ & 100
\end{tabular}


In evaluating the areas containing residual radioactivity to determine where cleanup might be necessary, Ford, Bacon \& Davis Utah ${ }^{13}$ used the formula

$$
\frac{C_{1}}{M_{1}}+\frac{C_{2}}{M_{2}}+\cdots+\frac{C_{n}}{M_{n}}
$$

where

$C_{1}, C_{2}, \ldots, C_{n}=$ concentration of radionuclides

and

$M_{1}, M_{2}, \ldots, M_{n}=$ working criteria for these radionuclides.

Using this formula, cleanup was determined to be necessary if

$$
\sum_{0}^{n} \frac{C_{i}}{M_{i}} \geq 1.0
$$

\subsection{Other Agencies Involved in Implementation of the Proposed Action}

Most of lower Pueblo Canyon is owned by DOE and is located in Santa Fe County. A small area in the western portion is owned by Los Alamos County. Lower Los Alamos Canyon is on San Ildefonso Indian Pueblo land. Interaction among these entities is necessary in the implementation of any remedial action.

Other agencies that may be involved are the state Environmental Improvement Division regarding radiological matters, the US Fish and Wildlife Service regarding the peregrine falcons in lower Pueblo Canyon (Sec. 4.6.3.2) and the state Historic Preservation Organization regarding archaeological and other historic sites. 


\subsection{ALTERNATIVES}

Five general FUSRAP alternatives are modified to produce a range of alternatives for a given site. Modification or elimination of alternatives is based on site-specific conditions. The five general alternatives are as follows.

(1) No action.

(2) Minimal action-Limit public exposure to radioactive sources.

(3) Stabilization/entombment-Cover contamination with clean soil or encapsulate it.

(4) Partial decontamination-Remove easily accessible or potentially active sources to prevent further contamination.

(5) Decontamination and restoration-Remove and rehabilitate all contaminated areas to make site available for unrestricted use.

Using these general alternatives and considering the conditions in lower Pueblo and Los Alamos Canyons, three working alternatives were considered. These alternatives are: no action, construction of a sediment trap in lower Pueblo Canyon to prevent transport of residual radioactivity into lower Los Alamos Canyon or the Rio Grande, and cleanup of lower Pueblo and/or lower Los Alamos Canyons. These al ternatives and their advantages and disadvantages are discussed in the following sections.

\subsection{Alternative I-Construction of a Sediment Trap in Lower Pueblo Canyon}

The configuration of lower Pueblo Canyon (described further in Sec. 4.1) is such that it already acts as a natural sediment trap. Enlargement and excavation of the stream bed in this region of the canyon could provide an enhanced sediment trap to prevent significant transport of residual radioactivity into lower Los Alamos Canyon or the Rio Grande.

Calculations show that virtually all of the runoff from the 100 -yr storm must be contained to assure settling of the silt and clay-size particles, which adsorb most of the residual radioactivity. This is a volume of about $1.4 \times 10^{5} \mathrm{~m}^{3}$ of water. ${ }^{14}$ Assuming a depth of $1.5 \mathrm{~m}$, a $240 \mathrm{~m}$ by $240 \mathrm{~m}$ sedimentation basin is required. This is not necessarily an unreasonably large basin to construct, but other considerations make the concept impractical. One is that a disposal site for $1.4 \times 10^{5} \mathrm{~m}^{3}$ of soil must be located. This volume of soil is 
unmanageable in terms of disposal at TA-54, the radioactive solid waste disposal site. The other consideration is that the sedimentation basin gradually will fill up and require reexcavation, with attendant problems of further worker exposure and additional sediment disposal. However, cleanup of the source term in Acid Canyon means that only the residual contamination in sediments along Pueblo Canyon is of concern.

\subsection{Alternative II-Cleanup of Lower Pueblo and Lower Los Alamos Canyon}

This has been rejected as a viable alternative. Measured concentrations of radionuclides in these canyons do not exceed, or even approach, FUSRAP criteria. There is no significant health hazard associated with the residual radioactivity that is present no or under any projected future conditions. Any attempt to cleanup the canyons would require excavation and disposal of an immense amount of sediment deposited over a distance of 15 to $20 \mathrm{~km}$.

Furthermore, cleanup of lower Pueblo and lower Los Alamos Canyons would only be partially effective unless the entire canyon system was cleaned up. Otherwise, transport of material from Acid and middle Pueblo Canyons would redeposit radioactive material in the lower part of the canyon system.

\subsection{Alternative III-No Action (Preferred Alternative)}

Under this alternative, no action would be taken in lower Pueblo or lower Los Alamos Canyons. The situation would remain unchanged and no costs would be incurred. Residual radioactivity present in the canyon sediments would gradually be further dispersed and washed into the Rio Grande River. This alternative represents current conditions as compared with the impacts that would result from implementation of other alternatives.

\subsection{AFFECTED ENVIRONMENT}

\subsection{Land Use}

4.1.1 Lower Pueblo Canyon. Lower Pueblo Canyon (Fig. 3) presently is under DOE ownership. The land is not being used, nor are there any immediate plans to do so. Should the land ever be released by DOE, residential development is a possibility. The County 
sewage treatment plant discharges into the upper part of lower Pueblo Canyon, and the canyon is bordered on the north by the Otowi ruins, a large, unexcavated archaeological site.

4.1.2 Lower Los Alamos Canyon. Lower Los Alamos Canyon is predominantly on San Ildefonso Indian Pueblo land. This section of the Pueblo is primarily used for grazing, although there are several residences at Totavi.

4.1.3 TA-54. Any soil removed from lower Pueblo Canyon or lower Los Alamos Canyon would contain residual radioactivity and would be taken for disposal to TA-54, the radioactive solid waste disposal facility at the Los Alamos National Laboratory. TA-54 is located on Mesita del Buey and is entirely on Laboratory property, as shown in Fig. 6. At TA-54, the soil would be handled according to Los Alamos National Laboratory procedures. ${ }^{15}$ A general description of TA-54 is given in a 1977 Los Alamos Scientific Laboratory report on waste disposal sites at the Laboratory. ${ }^{16}$ A more current status of the site is given in Reference 17.

4.1.4 Transportation Route. Trucks would transport excavated soil from lower Pueblo and lower Los Alamos Canyons to TA-54. The distance from lower Pueblo Canyon to TA-54 is 15 to $20 \mathrm{~km}$. The distance from lower Los Alamos Canyon to TA-54 is several kilometers more. The transportation route proceeds for most of the way along state Road 4 and Pajarito Road (see Fig. 6). These roads are heavily used from 7:00 to 8:30 a.m. and from 3:30 to 5:30 p.m. by Laboratory employees commuting from White Rock, Espanola, Santa $\mathrm{Fe}$, and other regional communities. Pajarito Road is located entirely on DOE property and theoretically could be closed to the public. However, this would be of little value because state Road 4 cannot be closed.

\subsection{Socioeconomics}

4.2.1 Demography. ${ }^{18}$ The estimated 1991 Los Alamos County population, based on the 1990 U. S. Census adjusted to July 1, 1991, is 18,200. Two residential and related commercial areas exist in the county. The Los Alamos townsite, the original area of development (and now including residential areas known as the Eastern Area, the Western Area, North Community, Barranca Mesa, and North Mesa ), has an estimated population of 11,400. The White Rock area (including residential areas known as White Rock, La Senda, 


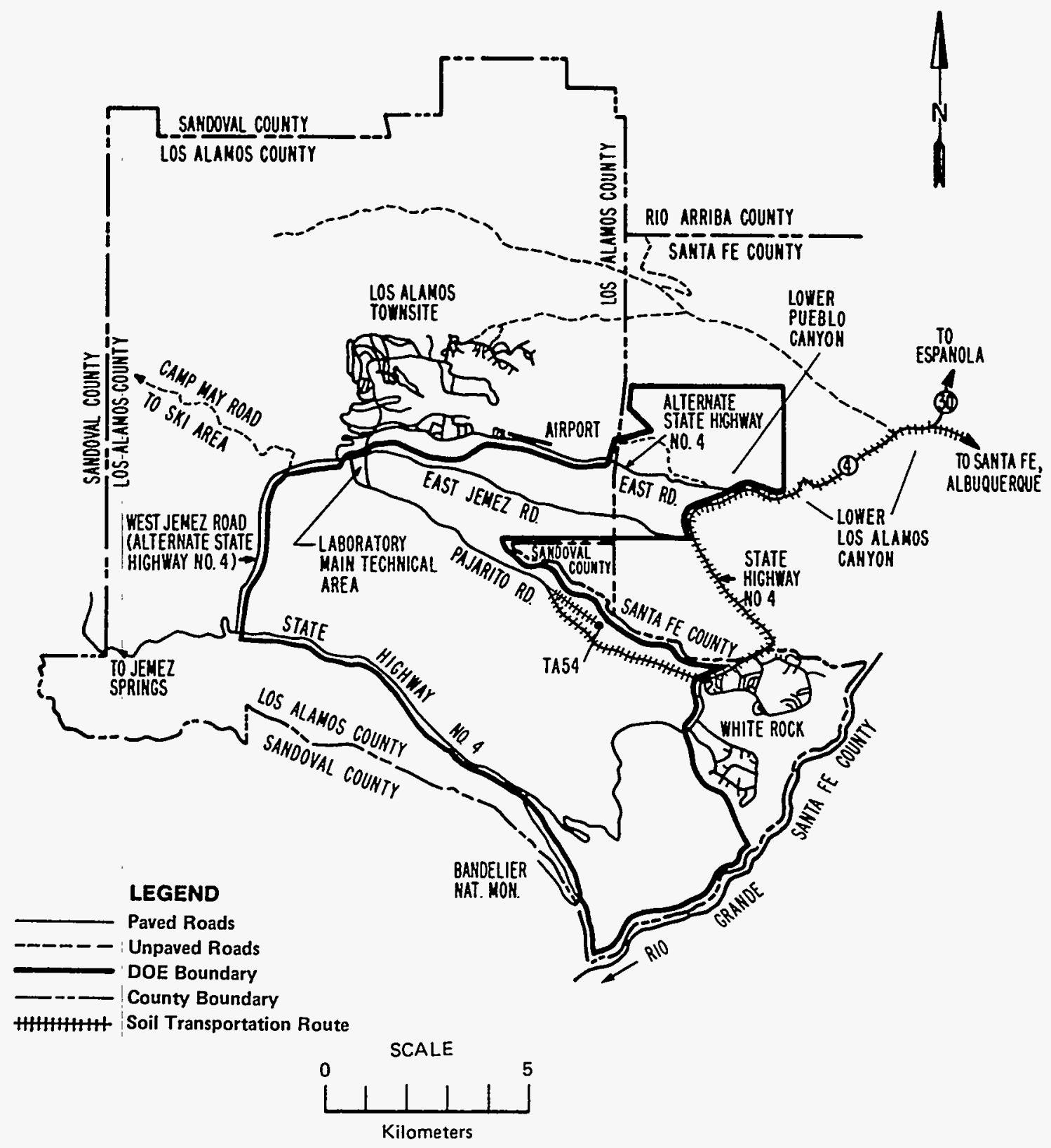

Fig. 6

Location of TA-54 and transportation route from lower Pueblo and lower Los Alamos Canyons. 
and Pajarito Acres) has about 6,800 residents. Population estimates for 1991 place about 21,800 people within an $80-\mathrm{km}$ (50 mile) radius of Los Alamos.

Los Alamos County is a relatively small county, $280 \mathrm{~km}^{2}$ in area, which was formed from portions of Santa Fe and Sandoval Counties in 1949. At the present time, slightly under $90 \%$ of county land is federally owned by the Los Alamos National Laboratory, the National Park Service, and the US Forest Service. ${ }^{19}$ Almost all of the privately owned land already is developed. Potential residents of the county are frequently forced to reside in surrounding communities, such as Española and Santa Fe, both because of the shortage of residentially developable land and because of the high housing costs resulting from this shortage.

4.2.2 Economy. ${ }^{19}$ The economy of Los Alamos is based primarily on governmental operations, with that sector directly accounting for about three-fourths of the employment within the county. This employment is associated with the federally funded operations of the Los Alamos National Laboratory and the associated activities of Johnson Controls Inc. (JCI), Protection Technology Los Alamos (PTLA), EG\&G, and the Los Alamos Area Office (LAAO) of DOE. The direct federally funded employment of the Laboratory, JCI, PTLA, EG\&G, and LAAO has averaged around $70 \%$ of total employment since 1967 . This has a large impact on the area surrounding Los Alamos County. Within Los Alamos, unemployment is extremely low, averaging around $5 \%$. The underemployed groups consist primarily of women and adolescents.

4.2.3 Institutional. ${ }^{19}$ As the only H-class county in the state, the powers of the Los Alamos County government are granted by the state legislature. The county coordinates planning activities with the North Central New Mexico Economic Development District and the State Planning Office. In 1973, the New Mexico State Legislature passed a law giving counties responsibility for managing subdivision of land, and Los Alamos County has since enacted subdivision regulations. The County Comprehensive Plan was adopted in 1964 and revised in 1976. In 1977, the County Zoning Ordinance was revised and adopted.

The Los Alamos County Charter was adopted in 1967. The county is governed by a seven-member county council, elected at large. Other elected officials include the county judge, the county clerk, the county assessor, and the county sheriff. The county council appoints the chief administrative officers, such as the county manager, attorney, and utilities 
manager. The county council also appoints a five-member utilities board, a three-member board of equalization, and a nine-member planning and zoning commission.

DOE has /administrative control of all of the Laboratory reservation. The responsibilities of the security force, operated under contract to the Laboratory by PTLA, include policing the Laboratory, generally to prevent the entry of unauthorized persons into restricted areas. An agreement with the Los Alamos County Police Department authorizes them to ticket traffic violators on the public access roads across DOE lands. The state police have authority over state highways, such as State Road 4. The Indian Tribal Police have authority over roads that cross tribal lands. In certain situations, this results in overlapping authorities.

Other federal agencies having resource management responsibilities in the region include the Forest Service and Farmers Home Administration of the US Department of Agriculture, the US Geological Survey and National Park Service of the US Department of the Interior, the US Army Corps of Engineers, the Bureau of Reclamation, the Bureau of Indian Affairs, the Fish and Wildlife Service, the Soil Conservation Service, and the Agricultural Stabilization and Conservation Service.

Many state agencies have jurisdiction over particular aspects of the County. The state Environmental Improvement Division has jurisdiction over environmental matters. The State Engineer Office and the New Mexico Water Quality Control Commission are responsible for water rights and water quality management. The two interstate compacts affecting water use in the region are the Rio Grande Compact of 1938, amended in 1948, and the Costella Creek Compact. There also is one international treaty, the Rio Grande Convention of 1906. Los Alamos County is a part of the declared Rio Grande Underground Basin. Other relevant state agencies include the National Resource Conservation Commission, the Department of Game and Fish, and the Parks and Recreation Commission.

The large percentage of federally owned lands in the region affects the institutional structure of the county. Only Congress is authorized to pass laws affecting the administration of federal property. The Multiple Use and Sustained Yield Act of 1960 and the Classification and Multiple Use Act of 1964 have changed the administration of lands in the region and affected the regional economy. 
4.2.4 Community Services. Sewage treatment for the community of Los Alamos is provided by a large treatment plant located just off the eastern end of Kwage Mesa in lower Pueblo Canyon. This treatment plant discharges continuously into lower Pueblo Canyon. The community of White Rock is served by a county sewage treatment plant that discharges into a tributary of the Rio Grande. All Laboratory sanitary sewage is treated at a centralized treatment facility at TA-46. The single exception is TA-21, which has its own treatment facility. The effluent fron the centralized treatment facility presently is pumped to TA-3 for discharge into Sandia Canyon.

Water for Los Alamos County is supplied by a series of wells that penetrate a deep aquifer underlying the Pajarito Plateau at depths ranging from $360 \mathrm{~m}$ at the western edge of the plateau to $180 \mathrm{~m}$ at the eastern edge of the plateau. ${ }^{19}$ The water supply system is operated and maintained for DOE by JCI. The county purchases water from DOE and distributes it to users throughout the county. See Reference 20 for discussions of the water supply system and its characteristics.

Natural gas for the county is purchased from DOE by the County and distributed to users throughout the county.

Telephone service to the entire county is provided by US West.

4.2.5 Archaeology. Big and Little Otowi Ruins are located between lower Pueblo Canyon and Bayo Canyon. These are major unexcavated ruins. A preliminary survey of lower Pueblo Canyon ${ }^{21}$ revealed four sites within the canyon and additional sites along the crest of the ridge to the south of the sewage treatment plant. As a result of this survey, the recommendation was made that a $100 \%$ systematic survey should be undertaken before any surface disturbance occurs.

The only survey conducted on San Ildefonso Indian Pueblo land was a survey of the sacred land in Mortandad Canyon. ${ }^{22}$ This survey, although preliminary in nature, turned up six sites, at least one of which gave indication of being a major ruin. On the basis of this known density in Mortandad Canyon, the occurrence of sites in Los Alamos Canyon, which has never been surveyed, is very likely. A systematic survey of Los Alamos Canyon is recommended before any remedial action is initiated in the canyon. 
In general, evidence exists of sporadic Indian use of the Pajarito Plateau for some 10 000 years. One Folsom point has been found, as well as many other archaic varieties of projectile points. Indian occupation of the area occurred principally from late Pueblo III (late 13th century) until early Pueblo IV (middle 16th century). Continued use of the region well into the historic period is indicated by pictographic art that portrays horses. ${ }^{23}$

Consequently, the plateau and canyons are dotted with hundreds of pre-Colombian Indian ruins. Many of the ruins on the southern part of the plateau are encompassed by Bandelier National Monument. Ruins on Laboratory. property have been surveyed by Frederick C. V. Worman and, more extensively, by Charlie. R. Steen, ${ }^{23,24}$ former Chief Archaeologist of the Southwest Region of the National Park Service and subsequently an archaeological consultant to the Los Alamos National Laboratory. Portions of the Pajarito Plateau not included in Bandelier National Monument or the Los Alamos National Laboratory have been surveyed more recently by J. N. Hill of the University of California.

There are three major ruins on Laboratory property: Tshirege, Cave Kiva, and Otowi Ruins. These sites were submitted for consideration for nomination to the National Register of Historic Places in 1973. The Otowi Ruins, comprising two large, unexcavated pueblos, are located in lower Pueblo Canyon, at a point where the canyon wall between Pueblo Canyon and Bayo Canyonjis partially broken down.

There are hundreds of small ruins on Laboratory property; these also have been submitted for consideration for nomination to the National Register of Historic Places. ${ }^{25}$

\subsection{Soils and Geology}

4.3.1 Soils. The soils in the vicinity of Pueblo and Los Alamos Canyons tend to be clay on the mesa tops with more sandy soils occurring in the canyon bottoms along the stream beds. The soils are derived from volcanic tuff and, thus, tend to be alkaline in nature, which is unusual for coniferous forest soils. Stream channels consist of granules and sand-size particles derived from weathering and erosion of volcanic material. Alluvium in the canyons tends to be thin in the upper reaches. It thickens with progression to the east, becoming several meters thick in the lower parts of the canyons. 
There is a soil survey of Santa Fe County, ${ }^{26}$ which includes lower Los Alamos Canyon. However, the information for Los Alamos Canyon in that survey appears to be derived from information on similar canyons elsewhere in Santa Fe County and does not take into account the influence of volcanic material washed down the canyon from the Pajarito Plateau. For this reason, the information in the Soil Survey of Los Alamos County ${ }^{27}$ probably is more appropriate, even though lower Los Alamos Canyon and lower Pueblo Canyon are not specifically addressed in that survey. Soils in these canyons can be considered to be similar to soils in adjacent canyons that were surveyed.

4.3.2 Geology. ${ }^{1}$ In general, canyons cut into the flanks of the mountains are in rocks of the Tschicoma Formation, whereas the canyons of the plateau are cut into and underlain by the Bandelier Tuff (Fig. 7). Along the eastern edge of the plateau, the channels are underlain by the Puye and Tesuque Formations. The basaltic rocks of Chino Mesa are interbedded in some areas with sediments of the Puye Formation. The Tesuque Formation forms the valley north of Otowi and is exposed in the lower canyon walls along the Rio Grande in White Rock and lower Los Alamos Canyons.

The rock units, from oldest to youngest, are the Tesuque Formation, Puye Formation, and basaltic rock of Chino Mesa of the Santa Fe Group; the Tschicoma Formation and Bandelier Tuff of the volcanic rocks of the Jemez Mountains; and the alluvium and soil of recent age.

The Tesuque Formation is a sequence of light colored sediments laid down as a coalescing alluvial fan and flood-plain deposits in the Rio Grande depression. The separate beds are composed of friable to moderately well-cemented, light-pink-grey to light-brown siltstone and sandstone that contain lenses of conglomerate and clay.

The Puye Formation consists of two members. The lower member is a poorly consolidated channel-fill deposit, which overlies the Tesuque Formation along the Rio Grande and in Los Alamos and Guaje Canyons. It is a grey, poorly consolidated conglomerate, consisting of fragments of quartzite, schist, gneiss, and granite, ranging in size from sand to boulders. Well-sorted lenses of silt and sand are present sporadically. The upper fanglomerate members are composed of pebbles, cobbles, and boulders of rhyolite, latite, quartz latite, and pumice, in a grey matrix of silt and sand. These rocks were derived from flows associated with the volcanic rocks of the Jemez Mountains. Sorting is poor, but 


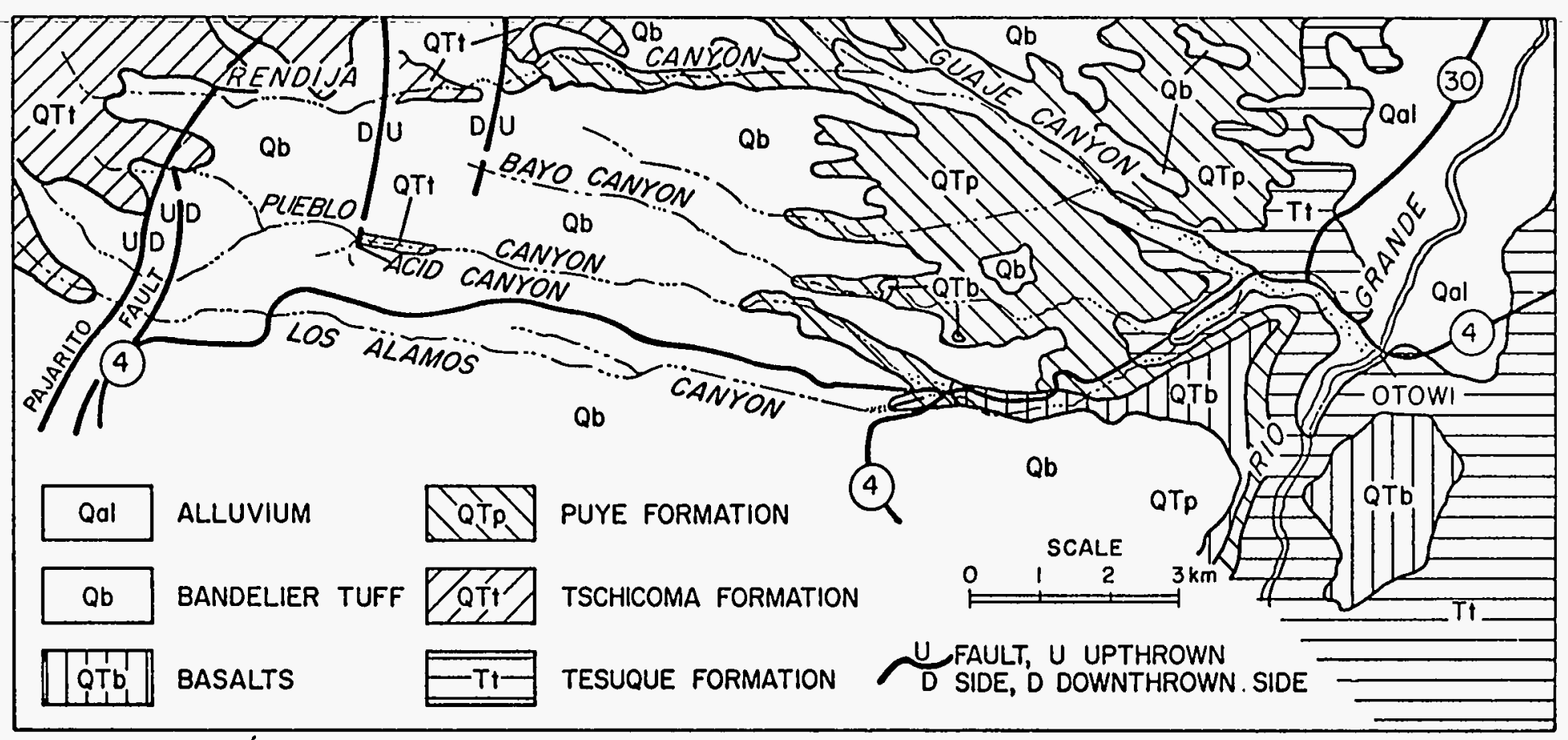

Fig. 7

Geologic map of a part of the Pajarito Plateau in the Los Alamos area. 
tongues and lenses of well-sorted pumiceous siltstone and water-lain pumice are present with the fanglomerate.

The basaltic rocks of Chino Mesa originated from volcanic vents on the Cerros del Rio to the southeast of the Los Alamos area. The basalt flowed north and northwest into the Los Alamos area, interfingering with the Puye Formation. The basalts range in color from grey to black and contain varying amounts of olivine, pyroxene, and plagioclase feldspar. Individual flows vary in thickness from a few meters to over $40 \mathrm{~m}$. Sediments may occur between the individual flows. The basalt caps the mesa of Cerros del Rio and is exposed in the steep walls of White Rock Canyon.

Volcanic rocks of the Jemez Mountains, along the eastern flanks of the Sierra de los Valles and on the Pajarito Plateau, are of the Tschicoma Formation and the younger Bandelier Tuff. The Tschicoma Formation is composed of undifferentiated latite and quartz latite flows and pyroclastic rocks that are highly fractured and jointed. Some intervals contain weathered zones and interflow breccia. These rocks form the core and flanks of the Sierra de los Valles. The Bandelier Tuff is composed chiefly of ashfall and ashflow tuff with some thin, water-lain sediments. The formation has been divided into three members: Guaje, Otowi, and Tshirege, from the oldest to the youngest. The Bandelier Tuff forms the upper part of the Pajarito Plateau.

The Guaje Member of the Bandelier Tuff is an ashfall pumice and water-laid pumiceous tuff that rests unconformably on older rocks. The base of the unit contains grey, lump-pumice fragments as much as $5 \mathrm{~m}$ in length. Rounded pebble-size fragments of light red rhyolite are present near the top. The Otowi Member of the Bandelier Tuff is a light gray, nonwelded, pumiceous rhyolite tuff that weathers to a gentle slope. Quartz and sanidine crystals, glass shards, minor amounts of mafic minerals, and varying amounts of rhyolite, latite, and pumice fragments are included in a fine-grained ash. The Otowi consists of a massive ashflow, with several beds of silt and water-laid pumice near the top. The Tshirege member of the Bandelier Tuff is composed of a series of ashflows of rhyolite tuff. The Tshirege unconformably overlies the Otowi and forms the caprock of the narrow mesas of the Pajarito Plateau. The rhyolite tuff is composed of quartz sanidine crystals and crystal fragments, rock fragments of rhyolite, dacite, and pumice in an ash matrix that ranges from nonwelded to welded. 
Alluvium, eroded from the Sierra de los Valles and the Pajarito Plateau, has been deposited in the canyons of the plateau. Near the heads of the canyons, bedrock is commonly exposed, but farther down the canyons, alluvium may be 10 to $80 \mathrm{~m}$ wide and as much as 30 $\mathrm{m}$ thick. Alluvial deposits in the canyons heading on the flanks of the Sierra de los Valles contain cobbles and boulders, with accompanying clay, silt, sand, and gravel derived from the Tschicoma Formation and Bandelier Tuff. Deposits in the canyons heading on the Pajarito Plateau contain clay, silt, sand, and gravel derived from the Bandelier Tuff. Clayey soil, derived from weathering of the Bandelier Tuff, covers most of the fingerlike mesas of the Pajarito Plateau.

The most prominent structural feature of the Pajarito Plateau is the Pajarito Fault Zone, which trends northward along the western edge of the plateau. It is a part of the complex fault system that formed the Rio Grande depression. This depression extends from southern Colorado through central New Mexico into northern Mexico. The Pajarito Fault Zone consists of normal faults that are downthrown to the east and displace rocks of the Bandelier Tuff, Puye Formation, and Tschicoma Formation. This displacement, estimated from the fault scarp, is 120 to $150 \mathrm{~m}$ north of Los Alamos and east of the Pajarito Fault. Two normal faults cut the Bandelier Tuff, the Puye Formation, and the Tschicoma Formation. These faults, downthrown to the west, form a depositional basin between them and the Pajarito Fault Zone. The faults extend into the mesa north of Pueblo Canyon. A northtrending depositional basin is formed in the Tesuque Formation beneath the central part of the Pajarito Plateau. The basin is filled with volcanic debris of the Puye Formation, overlain by the Bandelier Tuff. The bottom of the sediment-filled trough lies at a depth of about $1500 \mathrm{~m}$ below sea level. The eastern edge of the basin is formed by thick flows of basalt from Chino Mesa, 3 to $6 \mathrm{~km}$ west of the Rio Grande.

Further information on the geology of the Jemez Mountains can be found in a recent Los Alamos National Laboratory report. ${ }^{28}$

\subsection{Climatology}

4.4.1 General Climate. ${ }^{18}$ Los Alamos has a semiarid, continental mountain climate. The average annual precipitation of $45 \mathrm{~cm}$ is accounted for by warm-season convective rain showers and cold-season migratory storms. Forty percent of the annual moisture total falls during July and August; winter precipitation falls primarily from afternoon 
thundershowers. Winter precipitation falls primarily as snow, with heavy annual accumulations of about $130 \mathrm{~cm}$. Heavy localized thundershowers can at times cause severe runoff events through canyons, with attendant scouring of canyon bottoms.

Summers are generally cool and pleasant. Maximum temperatures are usually below $32^{\circ} \mathrm{C}$. The high altitude, light winds, clear skies, and dry atmosphere allow night temperatures to drop into the $12^{\circ}$ to $15^{\circ} \mathrm{C}$ range. Winter temperatures are typically in the range of $-10^{\circ}$ to $5^{\circ} \mathrm{C}$. Many winter days are clear, with light winds, so that strong solar radiation makes conditions quite comfortable even when air temperatures are cold.

Major spatial and dirunal variations of surface winds in Los Alamos are caused by the complex terrain. Under moderate and strong atmospheric pressure differences, flow is channeled by the major terrain features. Under weak pressure differences, a distinct daily wind cycle exists: a light westerly drainage wind during nighttime hours and a light easterly upslope wind during daytime hours. Interaction of the strong and weak pressure patterns gives rise to westerly flow predominance over the Laboratory and a more southerly predominance at the east end of the mesas.

4.4.2 Air Quality. No major emission sources exist in the Los Alamos area, although the Laboratory routinely releases small amounts of radionuclides and other chemicals. Data from routine monitoring systems indicate that, although radiation and radioactivity levels above background can be detected, no concentration guidelines (CGs) or other applicable standards are being violated. ${ }^{18}$

Air quality regulation compliance at the Laboratory, a small $(50 \mathrm{~mW})$ gas-fired power plant, the JCI asphalt plant, other unit operations, and the general status of air quality recently were reviewed. ${ }^{29}$ The review indicated that emission standards and ambient air quality standards are not being violated in the Los Alamos area. Air quality in the Los Alamos area should continue to be very good because of the proximity of Bandelier National Monument, the Wilderness Area of which is mandated as a Class I area under the Prevention of Significant Deterioration (PSD) provisions of the Clean Air Act. ${ }^{30}$ 


\subsection{Hydrology and Water Quality}

The Rio Grande, the master stream in North Central New Mexico, flows southwestward along the eastern edge of the Pajarito Plateau. The Rio Grande receives all runoff from the flanks of the Sierra de los Valles and the Pajarito Plateau. The main drainage area is about $37 \times 103 \mathrm{~km}^{2}$ in southern Colorado and northern New Mexico. The surface water discharge of the Rio Grande is measured at the US Geological Survey gauging station at Otowi, 1ocated east of Los Alamos County on State Road 4. The average discharge for 71 years of record at the station is about $40 \mathrm{~m}^{3} / \mathrm{s}$. The stream carries considerable amounts of suspended sediments. The annual suspended sediment load, 1948 through 1975, has ranged from $6.48 \times 10^{8}$ to $6.86 \times 10^{9} \mathrm{~kg}$, with an annual average of $2.2 \times 10^{9} \mathrm{~kg}$ for the 28 -year period of record. The annual volume of flow for this period has ranged from $4.65 \times 10^{8}$ to $1.88 \times 10^{9} \mathrm{~m}^{3}$, with an annual average of $1.03 \times 10^{9} \mathrm{~m}^{3}$.

Pueblo Canyon heads on the flanks of the Sierra de los Valles. Acid Canyon is tributary to Pueblo Canyon near the western edge of the Pajarito Plateau. Surface flow in sections of Pueblo Canyon occurs because of the release of sanitary effluents. As the effluents move downgradient, the surface flow is depleted by infiltration into the alluvium of the stream channel and by evapotranspiration. Thus, the surface flow in the lower reaches of the canyon is intermittent. Lower Pueblo Canyon intersects Los Alamos Canyon just below the junction of State Road 4 and State Road 502. At this point, Los Alamos Canyon leaves DOE property and flows across San Ildefonso Indian Pueblo land to the Rio Grande. Only during periods of heavy precipitation does surface flow reach the Rio Grande.

The storm runoff and sanitary effluents infiltrate from the stream channel to recharge small perennial bodies of ground water perched on underlying tuff or volcanic sediments in the alluvium. The volume of water in these stream-connected alluvial aquifers is largest during the spring from snowmelt and in the early summer from storm runoff. In late summer, fall, and winter, the volume of water declines. As the water in the alluvium moves downgradient in the canyon, part of it infiltrates into the underlying tuff and volcanic sediments. The alluvial aquifers are perched in the Puye basalt in Lower Los Alamos Formation in the midreach of Pueblo Canyon and on Canyon. They are of limited extent. The Bandelier Tuff does not contain any perched ground water in the Acid/Pueblo Canyon area. 
The main aquifer is at a depth of about $360 \mathrm{~m}$ beneath the western edge of the Pajarito Plateau, decreasing to a depth of about $180 \mathrm{~m}$ below the land surface at the confluence of Pueblo and Los Alamos Canyons. The main aquifer is separated from water in the alluvium by over 180 to $300 \mathrm{~m}$ of unsaturated tuff and volcanic sediments.

The upper surface of the main aquifer rises westward from the Rio Grande in the Tesuque Formation into the lower part of the Puye Formation beneath the central part of the plateau. The aquifer extends into the rocks of the Tschicoma Formation beneath the western edge of the plateau. Movement of water in the aquifer is from the recharge area, deep canyons on the flanks of the mountains and Valles Caldera, eastward to the Rio Grande, where part is discharged to the river from seeps and springs. Transit time of water in the aquifer from recharge area to discharge area is unknown. Tritium age dating of water from the main aquifer beneath the plateau indicates the water has been in transit for greater than 50 years. Aquifer tests on supply wells and test holes indicate movements ranging from 55 to $220 \mathrm{~m} /$ year.

\subsection{Biotic Environmental Factors}

4.6.1 General Ecology. Community types on the Pajarito Plateau range from piñon juniper woodland receiving 25 to $30 \mathrm{~cm}$ of rain annually at the eastern, lower part of the plateau to ponderosa pine forest receiving 45 to $50 \mathrm{~cm}$ annual precipitation at the western, higher edge. The canyons serve as cold air drainage channels from the mountains to the Rio Grande Valley and, thus, tend to be cooler and more moist than the mesa tops above. This allows vegetation typically characteristic of higher elevations to extend farther eastward along the canyon bottoms. The steep-sided and narrow upper portions of the canyons support pinefir communities, which give way to ponderosa pine and subsequently to piñon-juniper with progression down the canyons.

\subsubsection{Plants.}

4.6.2.1 Characterization. Both lower Pueblo Canyon and lower Los Alamos Canyon are in the piñon-juniper (Pinus edulis, Juniperus monosperma) zone found at the eastern portion of the Pajarito Plateau. Pinon-juniper begins to give way to arid grassland in the eastern portion of lower Los Alamos Canyon. Riparian habitat immediately adjacent to the Rio Grande supports a few cottonwood trees (Populus fremontii). Riparian habitat also exists 
along the stream channel in the upper portion of lower Pueblo Canyon where there is influence from the sewage treatment plant discharge.

Vegetation near the lower portion of middle Pueblo Canyon recently was surveyed. ${ }^{31}$ A tabulation of the plants found in this survey is given in Appendix A. The most common herbs and shrubs are listed in Table VIII. There is no comprehensive vegetation survey of either lower Pueblo Canyon or lower Los Alamos Canyon. The more mesic plants from the middle Pueblo Canyon survey would likely be found in the area influenced by the sewage treatment plant effluent. More xeric vegetation would be found in the lower portion of lower Pueblo Canyon and in lower Los Alamos Canyon.

4.6.2.2 Rare and Endangered Species. A study by Foxx and Tierney ${ }^{32}$ dealt with the status of the flora found on Laboratory property. Inferences concerning the flora in lower Pueblo and Los Alamos Canyons were drawn from their report.

There are no species from the Federal Endangered and Threatened Plant Species List present on Laboratory property. The grama grass cactus (Pediocactus papyracanthus), which is found on Laboratory property, has been proposed for inclusion in this list. The grama grass cactus prefers drier mesa tops at lower elevations, however, and so it is not likely to be found in the Pueblo/Los Alamos Canyon system.

Appendix B lists plants found in Los Alamos County and protected under New Mexico Statute 45-11. This statute has no penalties associated with it, per se, but destruction of plants covered by it can result in court action if anyone wishes to bring suit.

A list of 350 plant species was submitted by the New Mexico Heritage Program for consideration for protection under the Federal Endangered and Threatened Species List. Twenty-seven species from this list have been found in or around Los Alamos County, but none are known definitely to be present in lower Pueblo or lower Los Alamos Canyons.

\subsubsection{Animals.}

4.6.3.1 Characterization. Little quantitative information concerning the fauna of the Los Alamos area is available. Species lists are presented in the Environmental Impact Statement $^{19}$ for the Los Alamos Scientific Laboratory site. These lists are included as 


\section{COMMON HERBS AND SHRUBS OF THE LOWER MIDDLE PUEBLO CANYON AREA}

Grasses and Forbs

Andropogon scoparius

Boureloua gracilis

Bromus tectorum

Koelaria cristata

Taraxicum officinale

Verbascum thapais little bluestem

blue grama

cheatgrass

Junegrass

dandelion

woolly mullein

Shrubs and Subshurbs

Artemisia tridentata

Atriplex canescens

Chrysothamnus nauseosus

Fallugia paradoxa

Forestiera neomexicana

Gutierrezia microcephala

Prunus virginiana, var. melanocarpa

Quercus gambelii

Quercus undulata

Rhus trilobata

Robinia neomexicana big sagebrush

saltbush

chamisa or rabbitbrush

Apache plume

New Mexico olive

snakeweed

chokecherry

Gamble oak

scrub oak

squawbush

New Mexico locust

Disturbed Habitat Plants

Artemisia frigida

Chenopodium fremontii

Chrysopsis villosa

Croton texensis

Cryptantha jamesii

Erodium circutarium

Helianthus petiolaris

Lupinus causatus

Mirabilis multiflora

$\underline{\text { Salsola kali }}$

Viguiera multifora wormwood

lambsquarters

goldenweed

doveweed

James cryptantha

filaree

prairie sunflower

lupine

wold four o'clock

Russian thistle or tumbleweed

crownbeard 
Appendix $\mathrm{C}$ of this report. The lists are, however, uncertain. Occurrence of some species is unverified, although sightings have been reported, and other species that are not in the list are suspected to be present.

A biotic survey conducted by Miera et al. ${ }^{33}$ in Acid-Pueblo Canyon and other liquideffluent receiving areas noted the presence of 14 small mammal species, verified by trapping or sighting. These|species are listed in Table IX.

4.6.3.2 Rare and Endangered Species. Table $X$ gives a list of endangered and threatened species /developed for north central New Mexico by the New Mexico State Game Commission. $^{3}$ Although several of these species have been documented in Los Alamos County, the only one known to be present in proximity to Pueblo or Los Alamos Canyons is the peregrine falcon (Falco peregrinus). There is a peregrine falcon aerie in lower Pueblo Canyon, and the falcons use lower Pueblo Canyon as a hunting area.

\subsection{Summary of Radiological Conditions ${ }^{1}$}

\subsubsection{Radioactivity in Soils and Sediments.}

4.7.1.1 Present Conditions. The data for the lower Pueblo/lower Los Alamos Canyon Radiological Survey ${ }^{1}$ were taken in 1976 and 1977. Since that time, the routine soil and sediment sampling program conducted by the Environmental Surveillance Group at the Los Alamos National Laboratory has included radiochemical analyses of sediment samples from these canyons. These data have been reported in the annual surveillance reports ${ }^{18,34-38}$ and are summarized in Tables XI and XII. No particular trends are apparent.

Sections 4.7.1.2 and 4.7.1.3 reproduce the discussion from the radiological survey. ${ }^{1}$

4.7.1.2 Concentrations. The distribution pattern of ${ }^{239} \mathrm{Pu}^{*}$ on sediments and soils is displayed in Fig. 8. Quantitative data summaries are presented in Table XIII. The most important features of the pattern include the following.

*The designation ${ }^{239} \mathrm{Pu}$ is used in this discussion to signify the sum of ${ }^{239} \mathrm{Pu}$ and ${ }^{240} \mathrm{Pu}$. These isotopes are not separately distinguishable by normal alpha spectroscopy because their alpha particles have nearly the same energies. 
TABLE IX

\section{MAMMALS TRAPPED OR SIGHTED IN ACID/PUEBLO CANYON}

Eutamius minmus

Microtus pennsylvanicus

Mus musculus

Neotoma mexicana

Peromyscus manculates

Peromyscus truei

Reithrodontomys megalotis

Sciurus aberti

Sigmodon hispidus

Sorex nanus

Spermophilis lateralis

Spermophilus variegatus

Sylbilagus variegatus

Thomomys bottae least chipmunk

meadow vole

house mouse

Mexican woodrat

deer mouse

piñon mouse

western harvest mouse

tassel-eared squirrel

hispid cotton rat

dwarf shrew

golden-mantled squirrel

rock squirrel

cottontail rabbit

valley pocket gopher 


\section{TABLE $X$}

\section{STATE-LISTED ENDANGERED ANIMAL SPECIES FOR NORTH CENTRAL NEW MEXICO}

Group I - Endangered

Mammals

Birds

Amphibians

Fish
Black-footed ferret ${ }^{a}$

River otter ${ }^{\mathrm{a}}$

Peregrine falcon

Whooping crane

White-tailed ptarmigan ${ }^{\mathrm{a}}$

Sage grouse ${ }^{\mathrm{a}}$

Mexican duck ${ }^{\mathrm{a}}$

Bald eagle ${ }^{a}$
Group 2-Threatened

Pink marten ${ }^{\mathrm{a}}$

Mink $^{\mathrm{a}}$

Osprey

Red-headed woodpecker zone-tailed hawk

Jemez Mountain salamander

Suckermouth minnow ${ }^{2}$
Shovelnose sturgeon ${ }^{\mathrm{a}}$

(exterminated)

Bluntnose shiner

${ }^{\mathrm{a} N o t}$ documented in Los Alamos County. 


\section{TABLE XI}

\section{SEDIMENT ANALYSES FROM LOWER PUEBLO CANYON ${ }^{\mathrm{a}}$}

\begin{tabular}{|c|c|c|c|c|c|c|c|c|}
\hline & $\begin{array}{c}{ }^{137} \mathrm{Cs} \\
(\mathrm{pCi} / \mathrm{g})\end{array}$ & $\begin{array}{l}{ }^{241} \mathrm{Am} \\
(\mathrm{pCi} / \mathrm{g})\end{array}$ & $\begin{array}{c}{ }^{\infty} \mathrm{Sr} \\
(\mathrm{pCi} / \mathrm{g})\end{array}$ & $\begin{array}{l}{ }^{238} \mathrm{Pu} \\
(\mathrm{pCi} / \mathrm{g})\end{array}$ & $\begin{array}{l}{ }^{239} \mathrm{Pu} \\
(\mathrm{pCi} / \mathrm{g})\end{array}$ & $\begin{array}{l}\text { Gross } \alpha \\
(\mathrm{pCi} / \mathrm{g})\end{array}$ & $\begin{array}{l}\text { Gross } \beta \\
(\mathrm{pCi} / \mathrm{g})\end{array}$ & $\begin{array}{l}\text { Total U } \\
(\mu \mathrm{g} / \mathrm{g})\end{array}$ \\
\hline $1976-1977^{b}$ & $0.39 \pm 0.46$ & --- & $0.36 \pm 0.25$ & $-\cdots$ & $0.9 \pm 0.5$ & $-\cdots$ & $\ldots$ & $2.9 \pm 1.5$ \\
\hline 1977 & $0.11 \pm 0.12$ & $-\cdots$ & $0.09 \pm 0.16$ & $0.002 \pm 0.003$ & --- & -.- & --- & --- \\
\hline 1978 & $0.16 \pm 0.11$ & --- & $1.05 \pm 0.32$ & $0.001 \pm 0.002$ & $0.521 \pm 0.421$ & $2.7 \pm 1.4$ & $3.1 \pm 1.0$ & --- \\
\hline 1979 & $0.14 \pm 0.28$ & -- & $1.10 \pm 0.26$ & $0.002 \pm 0.006$ & $0.493 \pm 0.095$ & $4.2 \pm 2.0$ & $2.6 \pm 0.8$ & $4.3 \pm 0.8$ \\
\hline 1980 & $0.22 \pm 0.14$ & $0.03 \pm 0.008$ & $0.12 \pm 0.16$ & $0.004 \pm 0.004$ & $0.557 \pm 0.038$ & $4.6 \pm 2.0$ & $4.7 \pm 1.0$ & $\cdots$ \\
\hline 1981 & $0.14 \pm 0.06$ & --- & $0.10 \pm 0.12$ & $0.013 \pm 0.006$ & $0.700 \pm 0.000$ & $11 \pm 4.0$ & $64 \pm 12$ & --- \\
\hline 1982 & $0.44 \pm 0.12$ & $0.24 \pm 0.02$ & $0.41 \pm 0.12$ & $0.060 \pm 0.034$ & $15.5 \pm 2.4$ & $6.5 \pm 2.8$ & $5.9 \pm 1.4$ & $4.6 \pm 1.0$ \\
\hline Background $^{c}$ & $0.32 \pm 0.30$ & $-\cdots$ & $0.25 \pm 0.27$ & $0 \pm 0.004$ & $0.008 \pm 0.010$ & $4.0 \pm 3.2$ & $5.2 \pm 3.0$ & $1.8 \pm 1.3$ \\
\hline
\end{tabular}

${ }^{2}$ Data from surveillance reports represent maximum values.

${ }^{b}$ Data taken from Radiological Survey (Table E-V). ${ }^{1}$

'Data from Ref. 39, Table I. 


\section{TABLE XII}

SEDIMENT ANALYSES FROM LOWER LOS ALAMOS CANYON ${ }^{\mathrm{a}}$

\begin{tabular}{|c|c|c|c|c|c|c|c|c|}
\hline & $\begin{array}{c}{ }^{137} \mathrm{Cs} \\
(\mathrm{pCi} / \mathrm{g})\end{array}$ & $\begin{array}{c}{ }^{241} \mathrm{Am} \\
(\mathrm{pCi} / \mathrm{g})\end{array}$ & $\begin{array}{c}{ }^{\infty} \mathrm{Sr} \\
(\mathrm{pCi} / \mathrm{g})\end{array}$ & $\begin{array}{c}{ }^{238} \mathrm{Pu} \\
(\mathrm{pCi} / \mathrm{g})\end{array}$ & $\begin{array}{c}{ }^{239} \mathrm{Pu} \\
(\mathrm{pCi} / \mathrm{g}) \\
\end{array}$ & $\begin{array}{l}\text { Gross } \alpha \\
\text { (pCi/g) }\end{array}$ & $\begin{array}{l}\text { Gross } \beta \\
(\mathrm{pCi} / \mathrm{g})\end{array}$ & $\begin{array}{c}\text { Total U } \\
(\mu \mathrm{g} / \mathrm{g})\end{array}$ \\
\hline $1976-1977^{b}$ & $0.59 \pm 0.55$ & - & $0.27 \pm 0.19$ & -- & $0.24 \pm 0.26$ & -- & --- & $3.8 \pm 1.2$ \\
\hline 1978 & $52 \pm 0.82$ & $.005 \pm 0.012$ & $0.30 \pm 0.011$ & $0.002 \pm 0.005$ & $0.068 \pm 0.076$ & $2.9 \pm 1.4$ & $3.3 \pm 1.0$ & -- \\
\hline 1979 & $1.39 \pm 0.42$ & -- & $0.28 \pm 0.14$ & $0.010 \pm 0$ & $0.638 \pm 1.42$ & $3.0 \pm 5.3$ & $3.1 \pm 4.9$ & $3.0 \pm 3.1$ \\
\hline 1980 & $7.74 \pm 0.24$ & $0.037 \pm 0.008$ & $0.56 \pm 0.16$ & $0.019 \pm 0.006$ & $0.146 \pm 0.018$ & $6.1 \pm 2.8$ & $9.2 \pm 2.0$ & $3.1 \pm 0.6$ \\
\hline 1981 & $1.9 \pm 0.22$ & -.. & $3.2 \pm 1.4$ & $0.010 \pm 0.004$ & $0.012 \pm 0.016$ & $6.6 \pm 3.2$ & $6.9 \pm 3.2$ & -- \\
\hline 1982 & $0.61 \pm 0.10$ & $225 \pm 0.020$ & $0.44 \pm 0.20$ & $0.015 \pm 0.006$ & $0.730 \pm 0.060$ & $4.2 \pm 2.2$ & $6.8 \pm 1.6$ & $2.7 \pm 0.6$ \\
\hline Background $^{c}$ & $0.32 \pm 0.30$ & --- & $0.25 \pm 0.27$ & $0 \pm 0.004$ & $0.008 \pm 0.010$ & $4.0 \pm 3.2$ & $5.2 \pm 3.0$ & $1.8 \pm 1.3$ \\
\hline
\end{tabular}

${ }^{2}$ Data from surveillance reports represent maximum values.

b Data taken from Radiological Survey (Table E-V).1

Data from Ref. 39, Table I. 
- The highest concentrations are associated with the untreated waste outfall (Fig. 8).

- Some subsurface residual radioactivity is present in the immediate area of the former waste treatment plant location and along part of the alignment of the former industrial waste line.

- Plutonium is present at above-background levels in all the channels and banks from the discharge points in Acid Canyon, through middle and lower Pueblo Canyon, and in lower Los Alamos Canyon (Fig. 8).

- Concentrations in the channels and banks generally decline with increasing distance from the discharge points (Fig. 8).

- The banks have higher concentrations than the channels in given intervals, as would be expected from the intermittent stream character that scours the channels more frequently than the banks (Fig . 8 ).

A number of other facts are important to understanding the overall pattern of occurrence and distribution of radioactivity in the affected areas. These include the size of the areas, the isotopes other than ${ }^{239} \mathrm{Pu}$ present, and the variability of the data collected.

Within the canyon segments the affected areas have widths averaging between about 2.3 and $35 \mathrm{~m}$ and have a total length of about $17.5 \mathrm{~km}$ (Table XIV). Transuranic radioactive isotopes present in addition to ${ }^{239} \mathrm{Pu}$ include ${ }^{238} \mathrm{Pu},{ }^{241} \mathrm{Pu}$, and ${ }^{241} \mathrm{Am}$. They are accounted for in the evaluation by using ratios of their activities to the activity of ${ }^{239} \mathrm{Pu}$, as shown in Table XIV. A single set of ratios for current conditions was assumed for all study areas to simplify presentation of the result. The values were based on radiochemical analyses performed on a subset of the samples analyzed for ${ }^{239} \mathrm{Pu}$ and/or judgment of other factors, including variability of analyses and worldwide fallout. Future condition ratios were calculated from the current condition ratios to account for the decay of ${ }^{238} \mathrm{Pu}$ and ${ }^{241} \mathrm{Pu}$ and the ingrowth of ${ }^{241} \mathrm{Am}$. This use of a single set of ratios for all areas means the estimates of contributions from ${ }^{241} \mathrm{Pu}$ and ${ }^{241} \mathrm{Am}$ in Acid Canyon are probably overstated by factors of as much as 5 to 10 compared to the rest of the areas. 


\title{
TABLE XIII
}

SUMMARY OF DATA

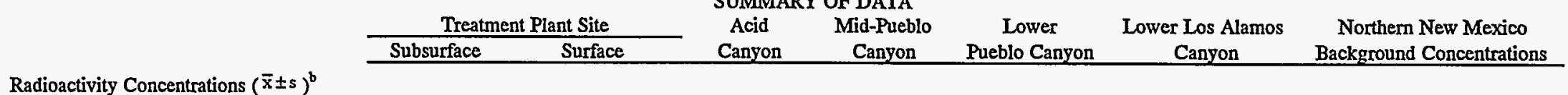

${ }^{239} \mathrm{pu}(\mathrm{pCi} / \mathrm{g})$

Maximum in stratum

Average in active channel

Average in inactive channel

Average in banks

35
$6.3 \pm 10.6$

163000

630

$31 \pm 29$

88
$1.1 \pm 1$.

15.5

$0.9 \pm 0.5$

9.3

$0.008 \pm 0.010$

$21000 \pm 49000$

$110 \pm 75$

$3.5 \pm 4.0$

$5.1 \pm 3.6$

$0.24 \pm 0.26$

$0.15 \pm 0.18$

Other Isotopes

Concentration increment

above background

${ }^{90} \mathrm{Sr}(\mathrm{pCi} / \mathrm{g})$

${ }^{137} \mathrm{Cs}(\mathrm{pCi} / \mathrm{g})$

Uranium $(\mu \mathrm{g} / \mathrm{g})$

${ }^{239} \mathrm{Pu}$ Inventory Estimate

Stratum inventory $(\mathrm{mCi}, \overline{\mathrm{x}} \pm 2 s \overline{\mathrm{x}})^{d}$

Percent of total (\%)

Distribution in Stratum

Active channel (\%)

Inactive channel (\%)

Bank (\%)

\author{
$0.1-10$ \\ (Range) \\ $0-3$ \\ (Range) \\ $1-36$
(Range)
}

$0.5-230$
(Range)
$0.1-180$
(Range)
$1-600$
(Range)

$1.0 \pm 1.4$

N.S.

N.S.

N.S.

$0.25 \pm 0.27$

$1.9 \pm 4$

N.S.

N.S.

$0.27 \pm 0.18$

$0.32 \pm 0.30$

(Range) (Range)

$1.3 \pm 1$

N.S.

$1.1 \pm 0.6$

$2.0 \pm 0.6$

$1.8 \pm 1.3$

\begin{tabular}{|c|c|c|c|}
\hline $98.9 \pm 52$ & $74.6 \pm 83.4$ & $422 \pm 281$ & $34.8 \pm 19.9$ \\
\hline 15.7 & 11.8 & 66.8 & 5.7 \\
\hline 9 & 5 & 4 & 32 \\
\hline - & - & 70 & 29 \\
\hline 91 & 95 & 26 & 39 \\
\hline 750 & 3250 & 6050 & 7400 \\
\hline 2.3 & 15 & 33 & 35 \\
\hline$\sim 1750$ & -50000 & 200000 & 260000 \\
\hline
\end{tabular}

Physical Characteristics

Channel length (m)

Average width (m)

Area with greater than

background concentration $\left(\mathrm{m}^{2}\right)$

$-3500$

ataken from Ref. 1.

's denotes the standard deviation of the data population; in this particular table, the numerical value of $\bar{x} \pm s$ represents the upper limit of the confidence interval on the mean with at least $95 \%$ confidence.

N.S. means no significant difference.

$d s_{\bar{x}}$ denotes the standard error of the calculated estimate; in this line, $\bar{x} \pm 2 s_{\bar{x}}$ represents an approximate $95 \%$ confidence interval of the estimate. 


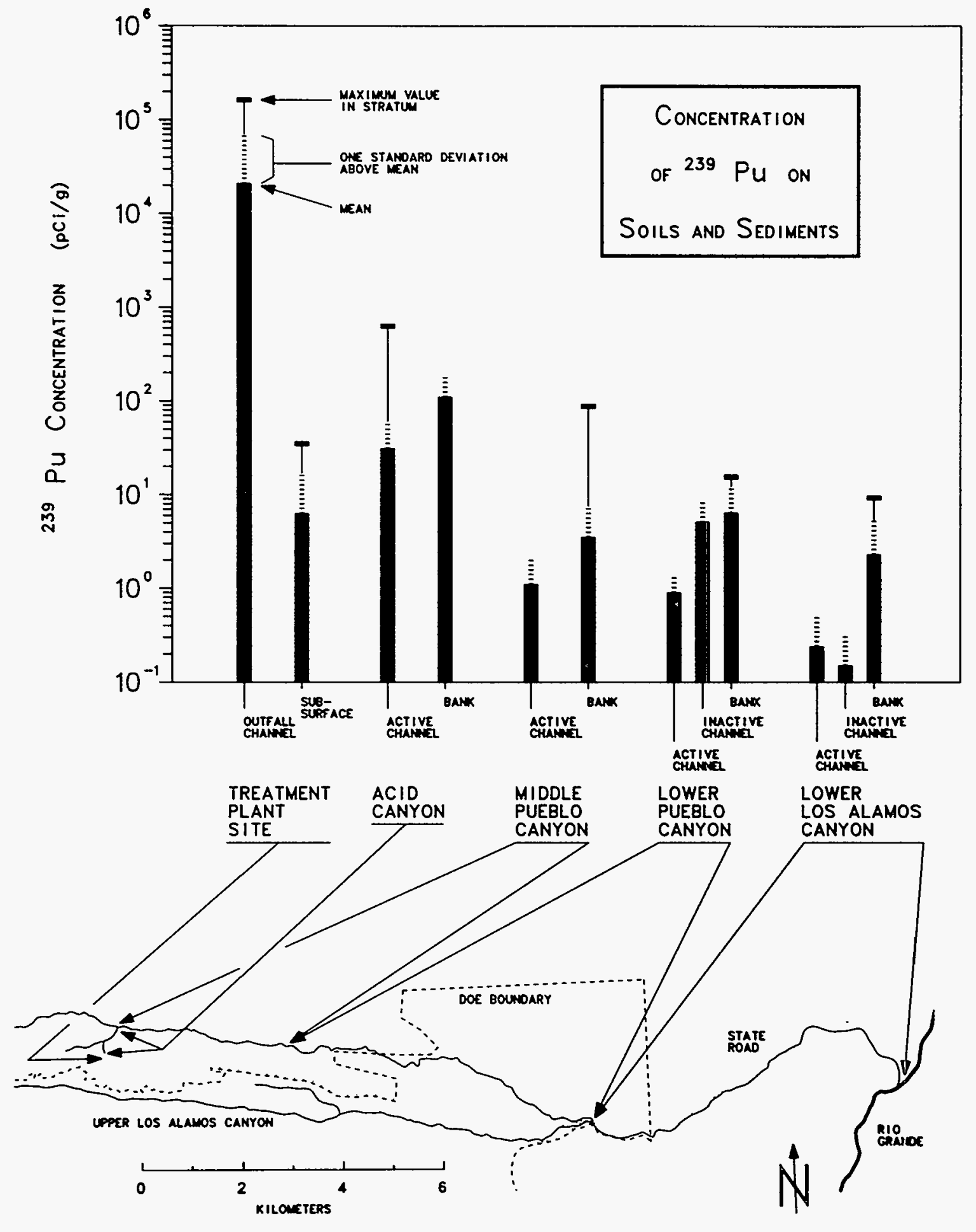

Fig. 8.

Concentration of ${ }^{239} \mathrm{Pu}$ on soils and sediments by location. 
Other radioactive isotopes present at concentrations with statistical significance above background in at least some areas include ${ }^{90} \mathrm{Sr},{ }^{137} \mathrm{Cs}$, and uranium. Data for these constituents are summarized in Table XIII. The values given are the statistically significant increment above regional background values. Where there was no significant increment (significance level $\alpha=0.05$ ), the entry in the Table is "N.S."

Even though a large number of samples were collected and analyzed, the physical areas involved and the complex natural processes involved in the dispersion of the radioisotopes from the discharge points made representative sampling extremely difficult. This is reflected clearly in the standard deviations of the concentrations presented in Table XIII. In most cases, the standard deviations are about the same value as the mean. The consequence of this is that all subsequent analyses of information based on the concentrations have a large uncertainty and can generally be considered to be accurate only within a factor of about 2. Most of the results are rounded to two significant figures to maintain reasonable consistency in the presentation, but even this probably implies more precision than is warranted. Within the ranges of uncertainties discussed, and considering the fact that runoff events do redistribute sediments within the channels, measurements made during this study are compatible with values obtained during previous special and monitoring studies. ${ }^{3}$

The standard deviations of the concentration data are given in Table XIII to indicate the large variability in the values. Because of the large variability, the mathematical standard deviation could be misinterpreted to mean that some of the actual concentrations were negative, an obvious physical impossibility. The standard deviations in such cases should be interpreted to indicate that the majority of the individual concentrations were between zero and the mean plus the standard deviation.

Preliminary evaluations of the data were performed using geometric means because physical processes such as hydrologic transport often have been found to be well described by some type of extreme value distribution. These evaluations gave means that often were about one-third the arithmetic means but had much larger standard deviations. The concentration data sets were too small to permit a clear choice between arithmetic and geometric mean representations. Accordingly, the arithmetic means were used for subsequent analyses of potential effects because they are simpler, are less likely to understate effects, and are the preferred statistical estimators for inventory calculations. 


\section{TABLE XIV}

\section{RELATIONSHIP OF ${ }^{239} \mathrm{Pu}$ AND OTHER TRANSURANIC CONCENTRATIONS ${ }^{\mathrm{a}}$}

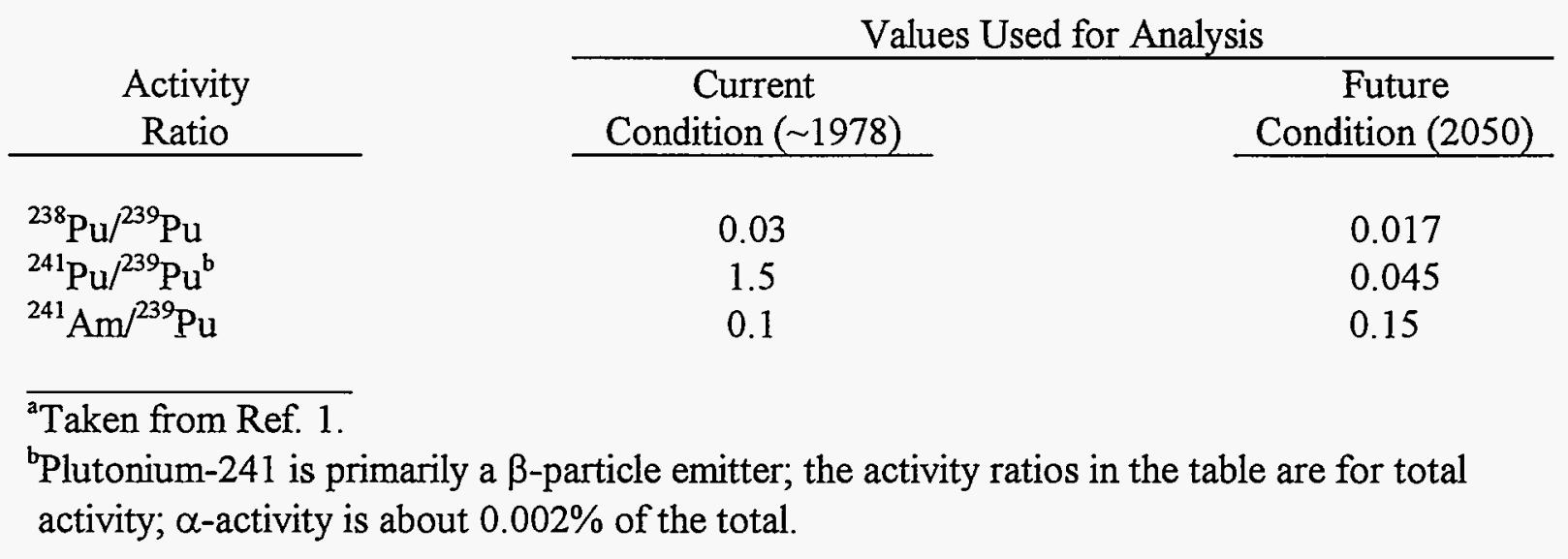


For inventory calculations, the standard errors of the means of both concentrations and channel widths were used to estimate confidence intervals of the computer inventories.

4.7.1.3 Estimated Inventory. Estimates of the amount of ${ }^{239} \mathrm{Pu}$ present in the affected canyon segments were calculated for two purposes. They provide a basis for making qualitative predictions of future redstribution by hydrologic transport of sediments, and they provide a basis for evaluating the plausibility of this analysis in accounting for the estimated releases into the canyons.

The ${ }^{239} \mathrm{Pu}$ inventories were estimated as the product of the average concentrations in the channels and banks of each segment and the estimated mass of affected sediments and soils derived from average measured physical dimensions and density. These estimates are depicted graphically in Fig. 9. Quantitative estimates are summarized in Table XIII. Two major features of the pattern are evident.

- Most of the plutonium is associated with the banks and inactive channels. This is as expected because the intermittent stream flow inundates the higher ground less frequently than the active channel.

- The largest proportion, about $67 \%$, of the plutonium is found in lower Pueblo Canyon. This also is as expected because the wider, flatter channel reduces flow rates and leads to deposition of suspended sediments.

The total estimated inventory, based on arithmetic means, is about $630 \pm 300 \mathrm{mCi}$ (approximate $95 \%$ confidence interval), or $7.9 \pm 3.8 \mathrm{~g}$. This is about 3 times the total of estimated and measured releases into Acid Canyon and the still-onsite DP Canyon, which discharges into Los Alamos Canyon. This is reasonable agreement given the uncertainties discussed in this section.

One detail of the inventory distribution (not shown in the summary graph or table) may be important to consideration of possible future sediment transport. The inventory estimated to be present in the inactive channel in lower Pueblo Canyon (Fig. 9) is dominated by the estimate for the interval between about 1.5 and $3 \mathrm{~km}$ upstream (west) from the confluences with lower Los Alamos Canyon. The inactive channel there is broad, giving a large estimated mass of contaminated sediments and soils. This led to a large inventory estimate even with 


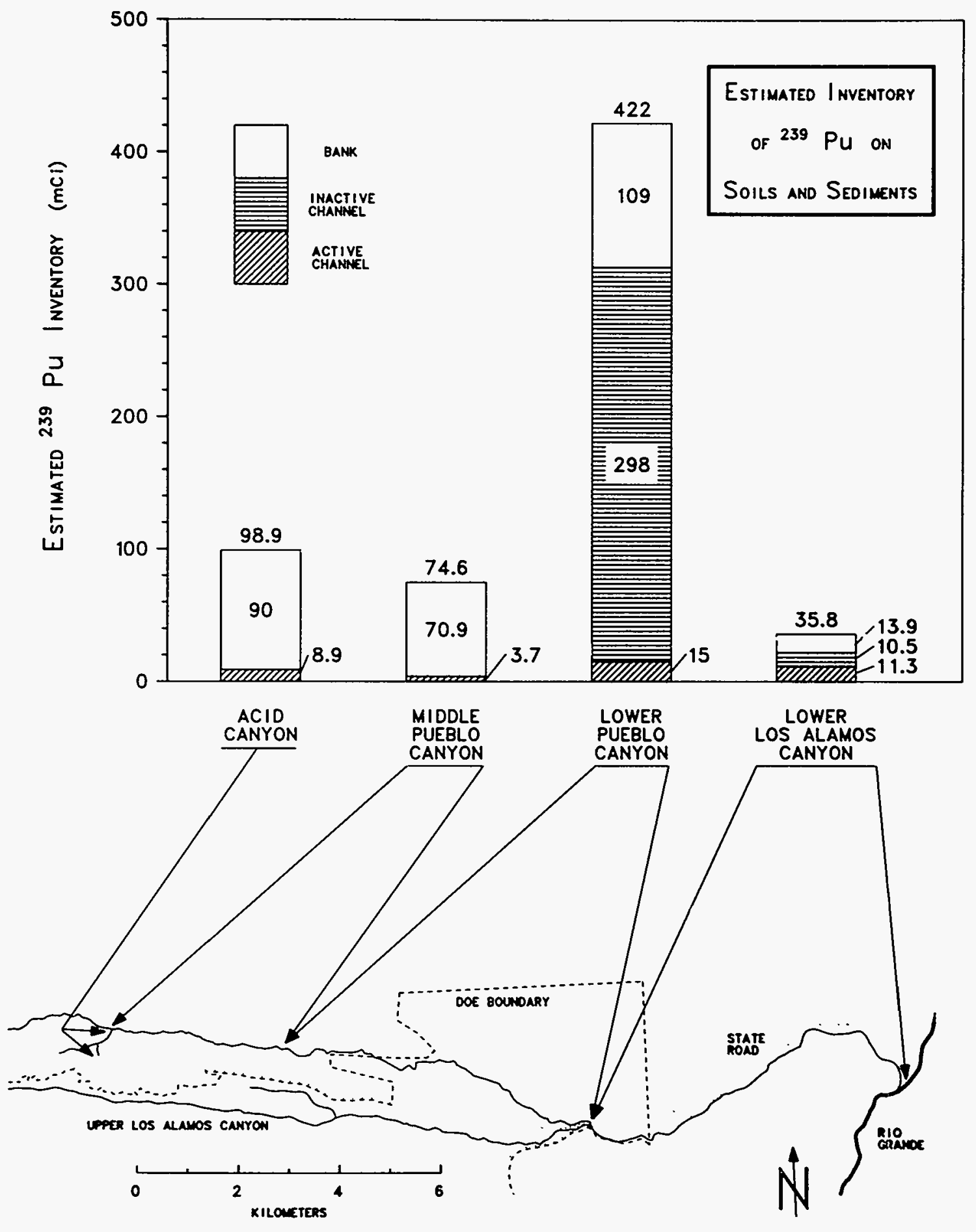

Fig. 9.

Estimated inventory of ${ }^{239} \mathrm{Pu}$ on soils and sediments by location. 
concentrations averages of about 3 to $10 \mathrm{pCi} / \mathrm{g}$. About $80 \%$ of the lower Pueblo Canyon inactive channel inventory is represented by this estimate, or about $40 \%$ of the total estimated inventory for all segments.

4.7.2 Airborne Radioactivity. Radioactivity on soils and sediments can be redistributed in the environment by resuspension, whereby small particles of soil or dust are moved and become airborne through the action of wind or other mechanical forces. This raises the possibility of exposure to the radioactivity through inhalation. This potential mechanism, or pathway, was examined by analyzing actual measurements of airborne radioactivity in the vicinity of Los Alamos and by applying a simple theoretical model to the canyon sediment and soil radioactivity data.

4.7.2.1 Present Conditions. Information for the Acid/Pueblo Radiological Survey ${ }^{1}$ was assembled from data collected by the air sampling network maintained as part of the routine environmental surveillance program at the Los Alamos National Laboratory. Data from 1974 through 1978 were used in the radiological survey. The same air sampling network still is in operation, and Table XV presents data from the network for 1979 through $1982,{ }^{18,36-38}$.along with the 1974 to 1978 data used in the radiological survey.

The stations for which data are presented include four on mesa tops within Los Alamos County. These are the Cumbres School, TA-21, Los Alamos Airport, and Bandelier stations. The TA-21 and Los Alamos Airport stations are located just west of lower Pueblo Canyon. The Bayo Sewage Plant station is near the midpoint of lower Pueblo Canyon, and the Santa Fe station is located 30 to $40 \mathrm{~km}$ to the southeast.

Although there appear to be large fluctuations in the data presented in Table XV, these fluctuations generally are within the uncertainties of the analyses and represent year-to-year fluctuations rather than variation among stations. There is no indication that any of the stations are being influenced by resuspension from Pueblo or Los Alamos Canyons.

Sections 4.7.2.2 and 4.7.3.3 reproduce the discussion from the radiological survey. ${ }^{1}$

4.7.2.2 Measurements. The basic conclusions presented in the radiological survey ${ }^{1}$ on the basis of analysis of the 1974 to 1978 data include the following: 


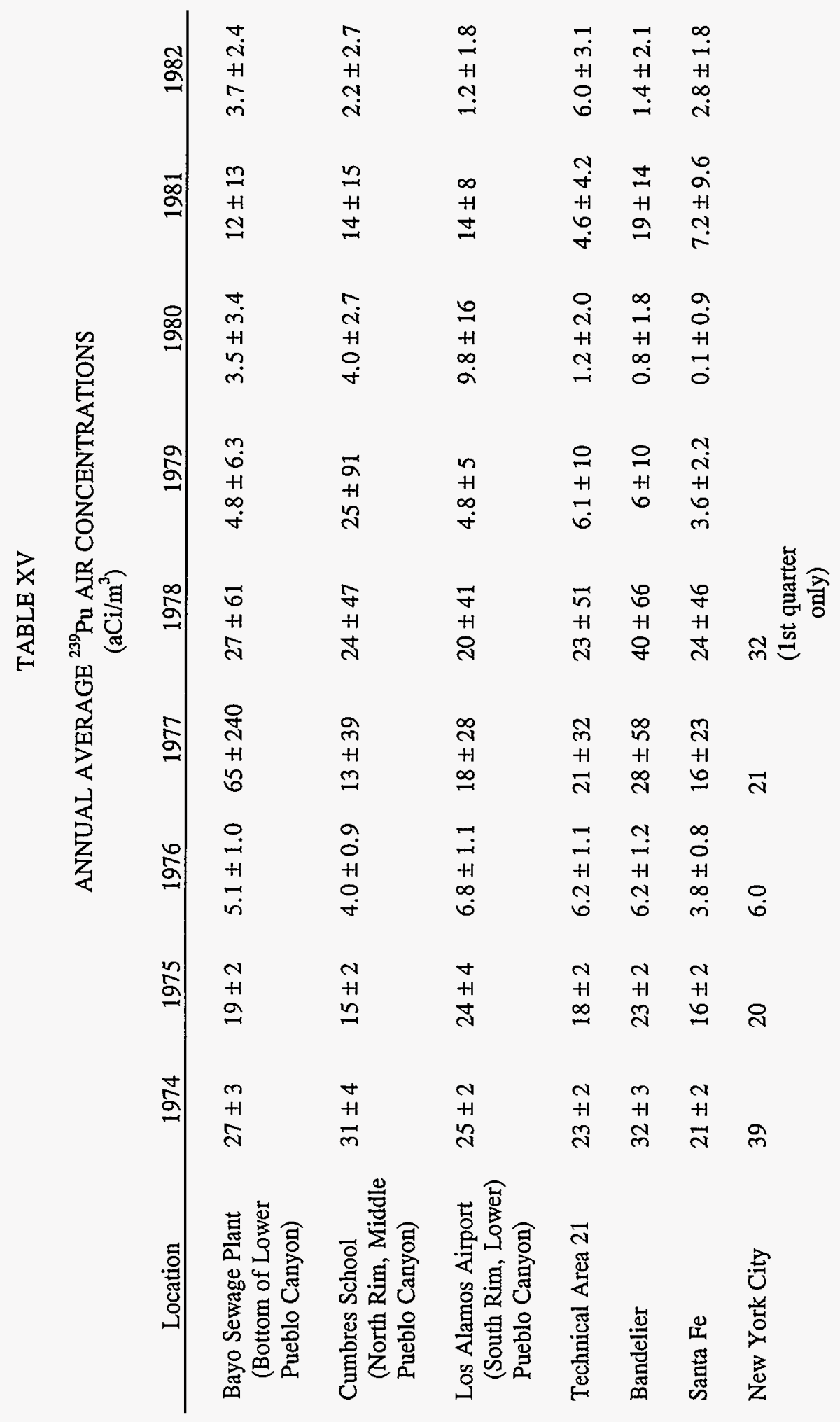


- Measurements of annual average ${ }^{239} \mathrm{Pu}$ concentrations found in Pueblo Canyon showed the same temporal pattern as locations representative of only worldwide fallout.

- Possible, but generally not statistically significant, differences in individual airborne plutonium concentration measurements during 6- to 8-week sampling periods during 1976 and 1977 at various locations in Los Alamos apparently were unrelated to proximity to Pueblo Canyon or to measurements of total airborne particulates.

- Measurements during 1 year (1976) of particularly low worldwide fallout levels permitted a good estimate of the long-term maximum potential contribution of resuspension to airborne concentrations of plutonium in Pueblo Canyon. This estimate $\left(3 \mathrm{aCi} / \mathrm{m}^{3}\right)$ is about $0.005 \%$ of the appropriate DOE CG, or $0.3 \%$ of the proposed EPA derived air concentration limit.

The most useful data of the 5 years analyzed came from 1976 when the annual averages of airborne concentrations of ${ }^{239} \mathrm{Pu}$ were about 20 to $25 \%$ of preceding or succeeding years. This enhances the sensitivity of any analysis looking for local effects because any such effects would be a much larger proportion of the total measurement. Two factors contributed to the unusually low year: (1) there was very little downmixing of worldwide fallout from the stratosphere into the troposphere as usually occurs in the late spring, and (2) there had been no atmospheric nuclear tests since June 1974.

The data on ${ }^{239} \mathrm{Pu}$ concentrations measured during 1976 at the sewage treatment plant in Pueblo Canyon, in Santa Fe, and in New York are shown in Fig 10. In general, all three locations display the same pattern throughout the year, in most cases differing by less than the measurement errors. The data from Santa Fe are assumed to represent fallout background for northern New Mexico well beyond any potential influence of Los Alamos operations or resuspension from the canyon areas. During the first and seventh sampling periods (12/12/75 to $2 / 2 / 76$ and $9 / 13 / 76$ to $10 / 26 / 76$ ), the airborne ${ }^{239} \mathrm{Pu}$ concentration in Pueblo Canyon was higher than at Santa Fe (significant for $\alpha=0.1$ but not for $\alpha=0.05$ ) by as much as $2.8 \pm 2.8$ $\mathrm{aCi} / \mathrm{m}^{3}$ (90\% confidence interval). During the fifth sampling period $(6 / 21 / 76$ to $8 / 2 / 76)$, the measurement in Pueblo Canyon was significantly less than in Santa Fe $(\alpha=0.05)$. However, the monthly geometric mean total particulates as measured in the Los Alamos townsite were higher during months of the second, third, fourth, eighth, and ninth sampling periods, when 


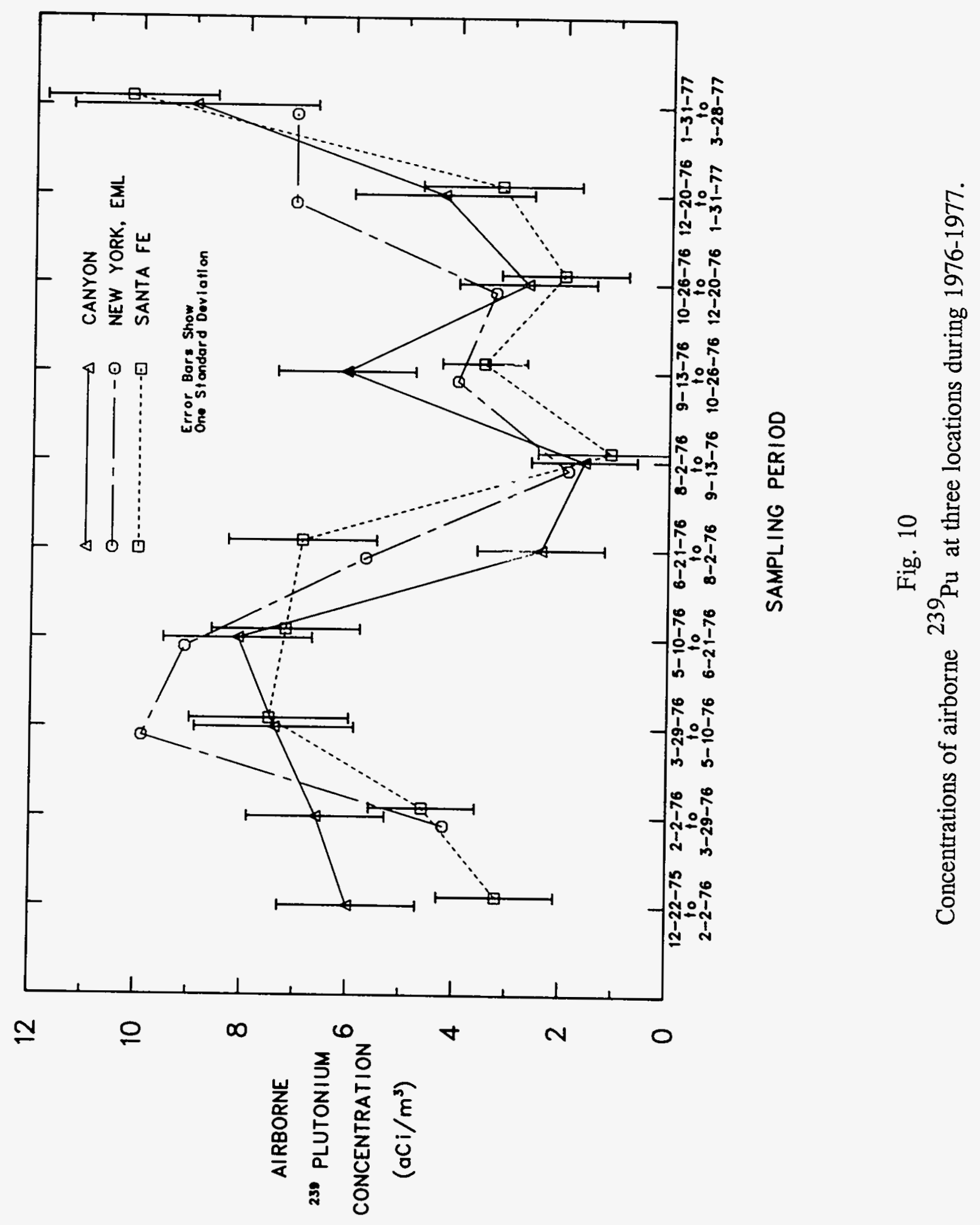


no significant differences in plutonium concentrations occurred. Thus, there are only marginal differences between airborne concentrations of ${ }^{239} \mathrm{Pu}$ in Pueblo Canyon and worldwide fallout levels measured elsewhere. No clear relation exists between airborne concentrations of ${ }^{239} \mathrm{Pu}$ and atmospheric dust loading. Evaluation of data from other air sampling locations in the Los Alamos townsite might be questioned because of a presumed greater potential for influence from airborne emissions from operating Los Alamos National Laboratory facilities. Some apparent differences in individual sampling periods may plausibly be related to spatial relationships, but there is no consistency in the pattern with time, and the annual averages over several years show no consistent differences related to location. Most important, additional data from many more sampling locations, as reported annually by the Los Alamos National Laboratory environmental monitoring program, have shown no statistically discernible effect on airborne ${ }^{239} \mathrm{Pu}$ concentrations outside the Los Alamos National Laboratory site.

The 1976 data are the soundest bases for an estimate of the maximum effect of sediment and soil resuspension on the airborne concentrations of ${ }^{239} \mathrm{Pu}$ in Pueblo Canyon. In addition to the very low worldwide fallout, 1976 was somewhat drier than average (total precipitation about $76 \%$ of long-term average), and the annual geometric mean of suspended airborne particulates was slightly higher than normal $\left(37.6 \mu \mathrm{g} / \mathrm{m}^{3}\right.$ compared to $\left.35 \mu \mathrm{g} / \mathrm{m}^{3}\right)$. These conditions all would be expected to maximize resuspension. The largest ${ }^{239} \mathrm{Pu}$ concentration increment above worldwide fallout measured during the year was $2.8 \mathrm{aCi} / \mathrm{m}^{3}$ in Pueblo Canyon (as compared to Santa $\mathrm{Fe}$ ). This value, rounded to $3 \mathrm{aCi} / \mathrm{m}^{3}$, was used in subsequent analyses as the upper bound on the average increment of ${ }^{239} \mathrm{Pu}$ airborne concentration that could be expected over a typical year.

The likely maximum short-term concentration of airborne ${ }^{239} \mathrm{Pu}$ in Pueblo Canyon was based on one anomalous measurement that occurred during the last quarter of 1977 . The value was $166 \mathrm{aCi} / \mathrm{m}^{3}$, about 5 to 10 times greater than any other Los Alamos National Laboratory station measured during the same period, and was 2 to 3 times greater than measured during previous sampling periods in 1977. All stations measured higher concentrations in 1977 than in 1976 because there were fallout contributions from spring mixing as well as from three atmospheric nuclear tests by the Peoples Republic of China, two of which took place late in 1976 and one in September of 1977. The spatial and temporal variation in measurements was much larger because of these inputs. A final interpretive factor 
is that the geometric mean airborne particulate concentration during the last quarter was lower than during any previous quarter of the year, suggesting that contributions from resuspension were minimized. Despite these contributing uncertainties, the value (rounded to $170 \mathrm{aCi} / \mathrm{m}^{3}$ ) was taken as a likely maximum short-term concentration of airborne ${ }^{239} \mathrm{Pu}$ that might be expected in Pueblo Canyon.

4.7.2.3 Theoretical Estimates. A theoretical model was applied as another approach to resuspension and as a means of estimating the contribution of resuspension in other parts of the canyon system where no direct measurements were available. The mass loading model was selected because of conceptual simplicity. Estimated airborne concentrations of radioactivity were calculated as the product of the mass concentration of particulates in the air and the activity concentration of radioactivity on the soil. Refinements were included to account for the observed higher concentrations on the smaller, more resuspendible particles (enrichment factor) and for the small proportion of the area containing residual radioactivity along the channels (area modification). Details of the assumptions and calculations are presented in Ref. 1. The enrichment factor was calculated using actual data on activity fractions for different particle size increments from previous radioecology studies in the Los Alamos Canyons and the method described in Ref. 39. Soil and sediment concentrations were taken to be the arithmetic means for the various channel and bank components of the canyon segments, with some adjustment to account for the slightly higher concentrations occurring in the top $1-\mathrm{cm}$ layer. The area modification was taken to be the ratio of the channel and bank area considered to contain residual radioactivity to the horizontal projection of the canyon area containing the segment. The annual geometric mean particulate mass loading observed in the Los Alamos townsite, $35 \mu \mathrm{g} / \mathrm{m}^{3}$, was used as representative of the area.

Table XVI presents estimates of incremental airborne ${ }^{239} \mathrm{Pu}$ concentrations attributable to resuspension as calculated from both the actual measurements and the mass loading model. The range of annual average concentrations of ${ }^{239} \mathrm{Pu}$ measured in Santa Fe is included at the bottom of the table for comparative purposes. The other columns give the relation of the estimated concentration increments and background to the DOE CG and to the proposed EPA derived concentration limit. The DOE CG $\left(60000 \mathrm{aCi} / \mathrm{m}^{3}\right)$ is that for ${ }^{239} \mathrm{Pu}$ in uncontrolled areas (accessible to the public) with continuous occupancy and with the lung considered as the critical organ. The EPA value $\left(1000 \mathrm{aCi} / \mathrm{m}^{3}\right)$ is given in its proposed federal guidance as a derived air concentration that can reasonably be predicted to result in dose rates less than the 
TABLE XVI

POTENTIAL CONTRIBUTIONS OF RESUSPENSION TO ${ }^{239} \mathrm{Pu}$ AIRBORNE RADIOACTIVITY ${ }^{\mathrm{a}}$

${ }^{239} \mathrm{Pu}$

Concentration $\left(\mathrm{aCi} / \mathrm{m}^{3}\right)$

\begin{tabular}{c}
$\begin{array}{c}\text { Per cent of DOE } \\
\text { Concentration } \\
\text { Guide } \\
(\%)\end{array}$ \\
\hline
\end{tabular}

Per cent of Proposed EPA Derived Limit (\%)

Analysis of Measured Airborne

$\mathrm{Pu}$ Concentrations

(Lower Pueblo Canyon)

Likely Maximum Annual

Inçrement from Resuspension

Likely Maximum Short-Term

Increment from Resuspension

Theoretical Contributions of

Resuspension to ${ }^{239} \mathrm{Pu}$ Ariborne

Concentrations

Acid Canyon

Middle Pueblo Canyon

Lower Pueblo Canyon

Low Los Alamos Canyon

Range of ${ }^{239} \mathrm{Pu}$ from

Worldwide

Fallout 1974-1978 at

Santa Fe, NM

Low (1976)

5-year average

High (1978)

${ }^{2}$ Taken from Ref 1.
3

170

0.005

0.3

0.01

0.04

0.06

0.005
71

25

36

2.9
0.03

17

-


guidance recommendations. The proposed EPA recommendations "...are for guidance on possible remedial actions for the protection of the public health in instances of presently existing contamination...". ${ }^{39}$ Most of the estimated annual increments are in the same range as worldwide fallout observed in recent years. The exception is the estimate for Acid Canyon, which is about 4.5 times the 5-year average for fallout. The estimated maximum short-term value for Pueblo Canyon is about 10 times the 5 -year average.

The activity ratios from Table XIV may be applied to these estimated ${ }^{239} \mathrm{Pu}$ concentrations to obtain estimates of other transuranics. As the proposed EPA derived limit applies to transuranic alpha activity, only the alpha portion of the ${ }^{241} \mathrm{Pu}$ activity should be counted. The total transuranic alpha airborne activity would thus be estimated as 1.13 times, or $13 \%$ more than the ${ }^{239} \mathrm{Pu}$ value for current conditions.

4.7.3 External Penetrating Radiation. Radioactivity on soils and sediments can contribute to radiation doses by the emission of gamma and $\mathrm{x}$-rays. The potential increments of such external radiation that could be attributed to residual radioactivity were addressed in this study by measurements in the environment and by theoretical calculation.

Measurements were made during the first quarter of 1978 by thermoluminescent dosimeters (TLDs) placed at 20 locations in the vicinity of the treatment plant site and along the different canyon-bottom segments. ${ }^{3}$ These measurements represented total doses without discrimination between the contribution from the residual radioactivity and that from natural cosmic and terrestrial sources. Accordingly, they can be compared to measurements made in areas representing only natural sources and to estimates of potential residual radioactivity contributions. Such estimates are subject to considerable uncertainty because of large temporal and spatial variation in natural background.

Natural background external penetrating radiation variations are well documented in the Los Alamos area. Most of the variation is from differences in the terrestrial component because the cosmic component is almost entirely determined by elevation above sea level. In the Los Alamos area, the cosmic contribution is about $60 \mathrm{mrem} /$ year, or about $6.8 \mu \mathrm{rem} / \mathrm{hour}$. The terrestrial component, on the other hand, ranges from about 30 to $90 \mu \mathrm{rem} / \mathrm{yr}$, or about 3 to $10 \mu \mathrm{rem} /$ hour, depending on time and location. The variety of geologic formations with different amounts of natural radioactive elements (principally potassium and the uranium and 
thorium chains) determines most of this range. Temporal differences, largely associated with soil moisture and snow cover, which affect the accumulation of natural radon daughters, often amount to as much as $\pm 25 \%$ from one quarter to the next at a given location. These geologic and temporal variations in the terrestrial component resulted in total quarterly dose measurements for the 12-station perimeter group of the Los Alamos National Laboratory routine monitoring program ranging from 9.4 to $17.4 \mu \mathrm{rem} /$ hour between 1976 and 1978 . These stations are located on the mesas in the townsite and at other places adjacent to the Los Alamos National Laboratory boundary.

During the first quarter of 1978, the perimeter group measured an average of 12 $\mu \mathrm{rem} / \mathrm{hour}$, slightly lower than the 4-year average of $13.4 \mu \mathrm{rem} /$ hour, as shown in Table XVII. The TLD measurements in the four canyon areas averaged 12 to $19 \mu \mathrm{rem} / \mathrm{hour}$. Individual measurements contributing to the averages had $95 \%$ confidence intervals of \pm 10 to $17 \%$, with the implication that the accuracy of the means cannot be much better in spite of the small standard deviations of the means. There is no significant difference between the lower Los Alamos or lower Pueblo Canyon averages and the perimeter group average taken to represent typical background for the area.

Significant support for these conclusions comes from the theoretically calculated contributions to be expected from the average measured concentrations of radioactivity on the sediments and soils in different strata. Dose rates from above-background concentrations were calculated for ${ }^{137} \mathrm{CS},{ }^{234} \mathrm{U},{ }^{238-39} \mathrm{Pu}$, and ${ }^{241} \mathrm{Am}$. The method assumed that doses were from an infinite plane, with the radioactivity distributed vertically, and accounted for absorption and scattering in the soil. ${ }^{1}$ The estimated total contributions to doses from these isotopes are presented in Table XVII. These calculated values are compatible with and support the TLD measurements and interpretation of importance of variations from natural factors.

The highest estimates of dose contributions from residual radioactivity in the soil were based on measurements of concentrations in the small areas with the highest levels of radioactivity. In the vicinity of the untreated waste outfall, the estimate of $50 \mu \mathrm{rem} / \mathrm{hour}$ results mainly from ${ }^{241} \mathrm{Am}$ and ${ }^{137} \mathrm{Cs}$. The infinite plane assumption obviously overstates the estimate because the maximum concentrations occur in areas with dimensions on the order of tens of centimeters. Similarly, in the vicinity of the vehicle decontamination facility, where the maximum residual radioactivity occurs in areas of a few meters, the $40 \mu \mathrm{rem} / \mathrm{hour}$ estimate also is overstated. 
TABLE XVII

\section{EXTERNAL PENETRATING RADIATION \\ MEASUREMENTS AND ESTIMATES OF CONTRIBUTIONS \\ FROM RESIDUAL ACTIVITY ${ }^{\mathrm{a}}$}

$(\mu \mathrm{REM} / \mathrm{H})$

\begin{tabular}{|c|c|c|}
\hline Location & $\begin{array}{l}\text { Measurements by TLD } \\
\text { First Quarter } 1978\end{array}$ & $\begin{array}{l}\text { Theoretical Contribution from } \\
\text { Above-Background Contaminants }\end{array}$ \\
\hline & $(\overline{\mathrm{x}} \pm 1 \quad$ S. D. or range) & \\
\hline Lower Los Alamos Canyon & $12 \pm 1$ & $0.2^{\mathrm{b}}$ \\
\hline Lower Pueblo Canyon & $13 \pm 1$ & $<0.03^{b}$ \\
\hline Middle Pueblo Canyon & $16 \pm 1$ & $<0.01^{\mathrm{b}}$ \\
\hline Acid Canyon & $19 \pm 3$ & $1.1^{\mathrm{b}}$ \\
\hline $\begin{array}{l}\text { TA-45 Site } \\
\text { Untreated Waste Outfall }\end{array}$ & $\begin{array}{c}19 \pm 3 \\
16-18\end{array}$ & $50^{\circ}$ (maximum) \\
\hline Vehicle Decontamination Facility & $22-26$ & $40^{\mathrm{b}}$ (maximum) \\
\hline \multicolumn{3}{|l|}{$\begin{array}{l}\text { LANL Surveillance Program } \\
\text { Perimenter Group }\end{array}$} \\
\hline First Quarter 1978 & $12 \pm 1$ & \\
\hline Four-Year Group Average & $13.4 \pm 1$ & \\
\hline Range of Separate Station Values & $9.4-17.4$ & \\
\hline
\end{tabular}


During the course of the field work, many measurements were made with portable instruments. The readings observed with the instruments were compatible with these interpretations and the TLD measurements. Because of different energy responses, the readings from such instruments cannot be directly interpreted as dose estimates. ${ }^{1}$ The purpose of the instrumental surveys was to increase the confidence that no major areas of activity were overlooked.

\subsection{ENVIRONMENTAL CONSEQUENCES}

\subsection{Alternative I-Construction of a Sediment Trap in Lower Pueblo Canyon}

5.1.1 Radiological Consequences. Because lower Pueblo Canyon does contain the majority of the residual radioactivity in the canyon system, construction of a sediment trap will result in removal of much of the radioactive material. The amount of sediment and associated radioactive material prevented from washing farther down onto Indian land future runoff events will depend on the size of the sediment $\operatorname{trap}^{14}$ (Sec. 3.1). Radiological conditions in lower Los Alamos Canyon will remain essentially as they are at present, with some gradual decrease in concentration as existing residual radioactivity is washed into the Rio Grande by future runoff events.

5.1.2 Ecological Consequences. The only ecological impact will be in the lower portion of lower Pueblo Canyon where the sediment trap is constructed. This construction will entail removal of sediment and vegetation, consisting of herbs, low shrubs, and some small juniper trees. The vegetation in this area is somewhat ephemeral anyway, because of the meandering of the stream channel, and so vegetation removal will not have a major ecological impact.

Construction of a sediment trap will have no direct effect on the peregrine falcon aerie as it is located at the other end of this segment of the canyon, although some temporary disturbance of this portion of the falcon's hunting range undoubtedly will occur.

5.1.3 Land Use Impacts. Sediment trap construction will not have a significant land use impact in the lower portion of lower Pueblo Canyon as this section of the canyon presently consists of a rather wide and braided stream channel. The major impact would be in 
terms of finding a waste disposal site because there will be a large amount of sediment requiring disposal (Sec. 3.1).

5.1.4 Socioeconomic Effects. There will be no direct demographic or institutional effects associated with the sediment trap alternative.

From an archaeological standpoint, the sediment trap will be located far enough away from the Otowi ruins that no impact to these ruins will occur. However, a preliminary archaeological survey of lower Pueblo Canyon (Sec. 4.2.5) indicated that a more thorough archaeological survey of the canyon should be performed before any remedial action is undertaken. The economic effect of this alternative will be insignificant.

5.1.5 Risk to Individual Health and Safety. Under existing conditions, the risk to casual users and residents from the residual radioactivity in lower Pueblo and lower Los Alamos Canyons is negligible (Sec. 2.2.2.1). Removal of sediment for construction of a sediment trap will lessen the incremental dose and thus the risk even further (Sec. 2.2.2.2).

In the construction of the sediment trap, some contaminated soil would be excavated from lower Pueblo Canyon and transported to a radioactive waste disposal site. Small radiation doses, listed in Table $\mathrm{V}$, would be incurred by the construction workers, the truck drivers transporting the soil to the waste disposal site, and members of the public. Lifetime risks of cancer mortality resulting from these radiation exposures were estimated and are also shown in Table $\mathrm{V}$.

The highest additional lifetime risks of cancer mortality resulting from these exposures would be received by construction workers. The incremental lifetime risk of dying from any type of cancer is estimated to be $8 \times 10^{-7}$ ( 8 chances in 10000000 ) (the total risk, which includes a $2 \times 10^{-7}$ risk of bone cancer and a $6 \times 10^{-7}$ risk from lung cancer). Risks of cancer mortality to truck drivers and members of the public are at least an order of magnitude lower than this risk to construction workers. For perspective, this risk can be compared to the lifetime risk of dying of cancer from 1 year exposure to natural background radiation of $1.8 \mathrm{x}$ $10^{-5}$ (18 chances in 1000000$)$. Other risks commonly encountered in everyday life are listed in Table VI for further comparison. 


\subsection{Alternative II-Cleanup of Lower Pueblo and Lower Los Alamos Canyons}

5.2.1 Radiological Consequences. As discussed in Secs. 2.2.1.2 and 2.2.2.1, the doses and risks associated with the canyons in their present condition are negligible. Cleanup of the canyons will reduce doses and risks even further (Sec. 2.2.2.2).

5.2.2 Ecological Consequences. Although the entire length of the stream channel will be disturbed under the cleanup alternative, the actual ecological impact will be minimal. The vegetation, consisting of grass, low shrubs, and small junipers, will rapidly reestablish itself after the cleanup is completed. Until the vegetation is reestablished, the canyons will be somewhat more susceptible to scouring and erosion during runoff events.

Cleanup operations in the upper end of lower Pueblo Canyon will definitely impact the peregrine falcon aerie. The operation will have to be scheduled so that it does not interfere with the nesting and fledging seasons.

5.2.3 Land Use Impacts. Lower Pueblo and lower Los Alamos Canyons are, at the present time, little used, except for grazing and the residences in 1ower Los Alamos Canyon (Sec. 4.1.2). Cleanup operations will have little impact on present land use in the canyons because the impact will largely be confined to the stream channel and banks.

5.2.4 Socioeconomic Effects. There will be no direct demographic or institutional effects associated with the cleanup alternative. However, the potential exists for an archaeological impact if cleanup operations are undertaken in lower Pueblo Canyon and lower Los Alamos Canyon. In addition to the Otowi ruins in lower Pueblo Canyon, a preliminary survey of lower Pueblo Canyon found enough smaller ruins to recommend a comprehensive survey before any disturbance. Archaeological sites are also suspected to be present in lower Los Alamos Canyon (Sec. 4.2.5).

The economic impact of this alternative was not estimated since it is not considered to be a viable alternative (Sec. 3.2). The amount of contaminated soil that would have to be removed makes the idea infeasible, and, furthermore, no disposal area is available to receive that large a quantity of material. 
5.2.5 Risk to Individual Health and Safety. As a result of cleanup activities, cleanup workers, truck drivers, and the general public might receive some radiation dose. The maximum incremental lifetime risks of dying from cancer as a result of this dose was estimated for these three groups. These risks are summarized in Table V.

Cleanup workers would incur an additional lifetime risk of lung cancer mortality of $4 \mathrm{x}$ $10^{-6}(1$ chance in 250000$)$. The total additional lifetime risk of any type of cancer is $4.8 \times 10^{-6}$ present in (48 chances in 1000000 ). This is the highest risk encountered among these groups. For comparison, the lifetime risk of cancer mortality from a 1-yr exposure to natural background radiation is $1.8 \times 10^{-5}$ (18 chances in 1000000 ). The risk for 50-yr of exposure is $9 \times 10^{-5}$ ( 9 chances in 10000 ).

\subsection{Alternative MI-No Action (Preferred Alternative)}

5.3.1 Radiological Consequences. If a sediment trap is not constructed, or if cleanup operations are not undertaken, radiological risks and conditions will remain as discussed in Secs. 2.2.2.1 and 4.7.

5.3.2 Ecological Consequences. No new ecological consequences are associated with the no-action alternative. No endangered species will be threatened. No alteration of the landscape will occur. Conditions will remain the same as discussed in Secs. 4.5 and 4.6.

5.3.3 Land Use Impacts. There presently is little use of lower Pueblo Canyon (Sec. 4.1.1), and use of lower Los Alamos Canyon is restricted to a few residences and cattlegrazing activities (Sec. 4.1.2). Changes in land use are not anticipated unless lower Pueblo Canyon is removed from DOE ownership. Present land use will not be affected by the noaction alternative.

5.3.4 Socioeconomic Effects. No direct demographic, economic, institutional, archaeological, or other socioeconomic effects will occur under the no-action alternative.

5.3.5 Risk to Individual Health and Safety. There will be no human risk from remedial actions because none are occurring. Risks to casual users and residents will remain as discussed in Sec. 2.2.2.1. 


\section{REFERENCES}

1. Los Alamos National Laboratory, "Radiological Survey of the Site of a Former Radioactive Liquid Waste Treatment Plant (TA-45) and the Effluent Receiving Areas of Acid, Pueblo, and Los Alamos Canyons, Los Alamos, New Mexico," Department of Energy report DOE/EV-0005/30 (May 1981).

2. R. W. Ferenbaugh, T. E. Buhl, A. K. Stoker, and W. R. Hansen, "Environmental Analysis of Acid/Middle Pueblo Canyon, Los Alamos, New Mexico," Los Alamos National Laboratory report LA-9409-MS (August 1982).

3. International Commission on Radiological Protection, "Limits for Intakes of Radionuclides by Workers," Annals of the ICRP, Publication 30, Vol. 2, Number 3/4, Pergamon Press, New York (1980).

4. US Energy Research and Development Administration, "A Guide for Environmental Radiological Surveillance at ERDA Installations," Division of Safety, Standards, and Compliance report ERDA 77-24 (March 1977).

5. G. R. Hoenes and J. K. Soldat, "Age-Specific Radiation Dose Commitment Factors for One-Year Chronic Intake," US Nuclear Regulatory Commission document NUREG-0172 (November 1977).

6. L. J. Lane, W. D. Purtymun, and N. M. Becker, "New Estimating Procedures for Surface Runoff, Sediment Yield, and Contaminant Transport in Los Alamos County, New Mexico," Los Alamos National Laboratory report LA-10335-MS (April 1985).

7. G. Whelan, F. L. Thompson, and S. B. Yabusaki, "Multimedia Contaminant Environmental Exposure Assessment Methodology as Applied to Los Alamos, New Mexico," Battelle Pacific Northwest Laboratory report PNL-4546 (February 1983). 
8. A. J. Ahlquist, A. K. Stoker, and L. K. Trocki, "Radiological Survey and Decontamination of the Former Main Technical Area (TA-1) at Los Alamos, New Mexico," Los Alamos Scientific Laboratory report LA-6887 (December 1977).

9. J . W. Healy, "An Examination of the Pathways from Soil to Man for Plutonium," Los Alamos Scientific Laboratory report LA-6741-MS (April 1977).

10. J. W. Healy and J. C. Rodgers, "Limits for the Burial of the Department of Energy Transuranic Wastes," Los Alamos Scientific Laboratory report LA-UR-79-100 (January 15, 1979).

11. J. W. Healy, J. C. Rodgers, and C. L. Wienke, "Interim Soil Limits for D\&D Projects," Los Alamos Scientific Laboratory report LA-UR-79-1865-Rev. (September 12, 1979).

12. National Council on Radiation Protection and Measurements, "Basic Radiation Protection Criteria," NCRP report 39 (1971).

13. Ford, Bacon \& Davis Utah Inc., "Engineering Evaluation of the Acid/Pueblo Canyon Site, Los Alamos, New Mexico," Bechtel report 10-05-01A-001 (October 1981).

14. Environmental Surveillance Group, Los Alamos National Laboratory internal memorandum from Naomi M. Becker to Roger W. Ferenbaugh, "Sedimentation Basin in Lower Pueblo Canyon" (October 26, 1982).

15. Health Division, "Waste Disposal," Los Alamos Scientific Laboratory Health, Safety, and Environment Manual," Chapter 1, Section 7 (October 1979).

16. M. A. Rogers, "History and Environmental Setting of LASL Near-Surface Land Disposal Facilities for Radioactive Wastes (Areas A, B, C, D, E, F, G, and T)," Los Alamos Scientific Laboratory report LA-6848-MS, Vol. I (June 1977).

17. K. A. Balo and J. L. Warren, "Waste Management Site Plan," Los Alamos National Laboratory report LA-UR-81-3656 (December 1981). 
18. Environmental Protection Group, "Environmental Surveillance at Los Alamos During 1991," Los Alamos National Laboratory report LA-12572-ENV (August 1993).

19. Los Alamos Scientific Laboratory, "Final Environmental Impact Statement," Department of Energy report DOE/EIS-0018 (December 1979).

20. W. D. Purtymun, "Hydrologic Characteristics of the Main Aquifer in the Los Alamos Area: Development of Ground Water Supplies," Los Alamos National Laboratory report LA-9957-MS (January 1984).

21. Museum of New Mexico, Laboratory of Anthropology, memorandum from David $\mathrm{H}$. Snow, Supervisor, Contract Archaeology Section, to Colleen Olinger, Environmental Surveillance Group, "Archaeological Survey of Bayo-Pueblo Canyon Areas" (October 7, 1982).

22. J. C. Nemaric, "An Archaeological Clearance Survey of San I1defonso Sacred Land," Laboratory of Anthropology, Museum of New Mexico Progress Report (September 1975).

23. C. R. Steen, "Pajarito Plateau Archaeological Survey and Excavations, Los Alamos Scientific Laboratory report LASL-77-4 (May 1977).

24. C. R. Steen, "Pajarito Archaeological Surveys and Excavations, I," Los Alamos National Laboratory report LA-8860-NERP (April 1982).

25. Department of Energy, Los Alamos Area Office, letter from Gary M. Granere, Acting Area Manager, to the Keeper of the National Register of Historic Places, National Park Service (June 11, 1981) .

26. J. J. Folks, "Soil Survey of Santa Fe Area, New Mexico," USDA Soil Conservation Service report (August 1975).

27. J. W. Nyhan, L. H. Hacker, T. E. Calhoun, and D. L. Young, "Soil Survey of Los Alamos County, New Mexico," Los Alamos Scientific Laboratory report LA-6779MS (June 1978). 
28. B. W. Burton, "Geologic Evolution of the Jemez Mountains and Their Potential for Future Volcanic Activity," Los Alamos National Laboratory report LA-8795-GEOL (January 1982).

29. Los Alamos National Laboratory, internal memorandum from Roger W. Ferenbaugh, Environmental Surveillance Group, to Harry S. Jordan, Associate H-Division Leader, "Air Quality Regulation Review-Summary" (May 7, 1981).

30. 40 CFR 81.421 (Code of Federal Regulations, U. S. Government Printing Office, Washington, D.C., 1984 edition).

31. T. S. Foxx and G. D. Tierney, "Vegetational Analysis of a Canyon Ecosystem at Los Alamos," Los Alamos National Laboratory report LA-9576-MS (November 1982).

32. T. S. Foxx and G. D. Tierney, "Status of the Flora of the Los Alamos National Environmental Research Park," Los Alamos Scientific Laboratory report LA-8050NERP, Vol. I (May 1980).

33. F. R. Miera, Jr., K. V. Bostick, T. E. Hakonson, and J. W. Nyhan, "Biotic Survey of Los Alamos Radioactive Liquid-Effluent Receiving Areas," Los Alamos Scientific Laboratory report LA-6503-MS (January 1977).

34. Environmental Surveillance Group, "Environmental Surveillance at Los Alamos During 1977," Los Alamos Scientific Laboratory report LA-7263-MS (April 1978).

35. Environmental Surveillance Group, "Environmental Surveillance at Los Alamos During 1978," Los Alamos Scientific Laboratory report LA-7800-ENV (April, 1979).

36. Environmental Surveillance Group, "Environmental Surveillance at Los Alamos During 1979," Los Alamos Scientific Laboratory report LA-8200-ENV (April 1980).

37. Environmental Surveillance Group, "Environmental Surveillance at Los Alamos During 1981," Los Alamos National Laboratory report LA-9349-ENV (April 1982). 
38. Environmental Surveillance Group, "Environmental Surveillance at Los Alamos During 1982," Los Alamos National Laboratory report LA-9762-ENV (April 1983).

39. W. D. Purtymun, R. J. Peters, and A. K. Stoker, "Radioactivity in Soils and Sediments in and Adjacent to the Los Alamos Area, 1974-1977," Los Alamos Scientific Laboratory report LA-8234-MS (February 1980).

40. United States Geological Survey, "Water Resources Data for New Mexico, WaterData report NM-79-1 (1980).

41. Department of Energy, "Radiological Guidelines for Application to DOE's Formerly Utilized Sites Remedial Action Program," Oak Ridge Operations report ORO-831 (March 1983). 


\section{APPENDIX A \\ PLANTS OF PUEBLO CANYON}

Anacardiaceae

Rhus trilobata

Amaran thaceae

Amaranthus retroflexus

Boraginaceae

Crytantha jamesii

Lappula spp.

Lithospermum spp.

Cactaceae

Enchinocereus spp.

Puntia polycantha

Capparidaceae

Polansia trachyspermum

Chenopodiaceau

Atriplex canescens

Chenopodium graveolans

Chenopodium fremmontii

Salsola kali

Compositae (Asteraceae)

Antennaria parvifolia

Artemisia carruthii

Artemisia dracunculoides

Artemisia frigida

Artemisia ludoviciana

Artemisi tridentata

Aster bigelovii

Aster hesperius

Bahia dissecta

Brickellia california

Chrysopsis villosa

Chrysothamnus mauseosus

Conyza canadenis

Cosmos parviflorus

Dyssodia papposa

Erigeron divergens
Franseria pulchella

Compositae (cont.)

Gutierrezia pulchella

Happlopappus spinulosis

Helianthus annus

Helianthus petiolaris

Hymenopappus spp.

Hymenoxys argentea

Hymenoxys richardsonii

Lactuca serriola

Senecio multicapitatus

Thelesperma trifidum

Tragopogon dubius

Viguiera multiflorum

Cruciferae

Descurainia spp.

Cuppressaceae

Juniperus monosperma

Juniperus scopulorum

Cyperaceae

Carex spp.

Euphorbiaceae

Croton texensis

Euphorbia dentata

Euphorbia serpyllifolia

Fagaceae

Quercus gambelii

Quercus undulata

Geraniaceae

Erodium circutarium

Geranium caespitosum 
APPENDIX A (cont)

Gramineae (Poaceae)

Agropyron desertorum

Agropyron smithii

Andropogon scoparius

Aristida divaricata

Bouteloua curtipendulum

Bouteloua eriopoda

Bouteloua gracilis

Bromus spp.

Bromus tectorum

Festuca spp.

Koelaraia cristata

Muhlenbergia montana

Munroa squarrosa

Oryzopsis bymenoides

Poa spp.

Sitanion hystrix

Sporobolus contractus

Sporobolus spp.

Hydrophyllaceae

Phacelia spp.

Labiatae

Monarda pectinata

Leguminosae (Fabaceae)

Lupinus caudatus

Robinia neomexicana

Vicia american

Liliaceae

Allium cernum

Yucca baccata

Loasaceae

Mentzelia pumila

Malvaceae

Sphaeralcea
Nyctaginaceae

Mirabilis linearis

Mirabilis multiflorum

Oleaceae

Forestiera neomexicana

Onagraceae

Oenothera spp.

Orobanchaceae

Orobanche multiflonum

Pinaceae

Pinus edulis

Pinus ponderosa

Plantaginaceae

Plantago purshii

Polemoniaceae

Gilia aggregata

Gilia longiflora

Gila spp.

Poly gonaceae

Eriogonum cernuum

Eriogonum jamesii

Rumex spp.

Portulacaceae

Portulaca oleracea

Ranunculaceau

Pulsatilla ludoviciana

$\underline{\text { Rosaceae }}$

Cercocarpus montanus

Fallugia paradoxa

Potentilla spp.

Prunus virginia, var. melanocarpa 
APPENDIX A (cont.)

\section{Rutaceae}

Ptelea angustifolia

Salicaceae

Populus angustifolia

Saxifragaceae

Philadelphus microcephala

Scrophulariaceae

Castilleja integra

Orthocarpus purpureo-albus

Penstemon barbatus, vor. torreyi

Verbascum thapsis

Solanaceae

Datura meteloides

Physalis neomexicana

Tamaricaceae

Tamarix gallica

Urticaceae

Urtica gracilis

Vitaceae

Parthenocissus inserta 


\section{APPENDIX B \\ PLANTS ENUMERATED IN NEW MEXICO STATUE 45-1-11 \\ THAT ARE KNOWN TO OCCUR IN LOS ALAMOS COUNTY ${ }^{a}$}

\begin{tabular}{|c|c|c|c|}
\hline Family & Species & Common Name & General Habit \\
\hline Araliaceae & Aralia racemosa & American spiknard & $\begin{array}{l}\text { Shaded Mt Slopes } \\
2100-2700 \mathrm{~m} \\
(7000-9000 \mathrm{ft})\end{array}$ \\
\hline Ascelepiadaceae & Asclepia tuberosa & butterflyweed & $\begin{array}{l}\text { Gravelly Canyons } \\
2000-2100 \mathrm{~m} \\
(6500-7000 \mathrm{ft})\end{array}$ \\
\hline Cactaceae & $\begin{array}{l}\text { Echinocereus triglochidiatus } \\
\text { var: trigochidiatus } \\
\text { Echinocereus triglochidiatus } \\
\text { var: melanacanthus } \\
\text { Echinocereus virdiflorus } \\
\text { Mammillaria spp. }\end{array}$ & strawberry cactus & $\begin{array}{l}\text { Rocky Hills } \\
1500-1800 \mathrm{~m} \\
(5000-6000 \mathrm{ft})\end{array}$ \\
\hline Campanulaceae & Lobelia cardinals & cardinal flower & $\begin{array}{l}\text { Wet Ground } \\
1700-2100 \mathrm{~m} \\
(5500-7000 \mathrm{ft})\end{array}$ \\
\hline Cornaceae & Cornus stolonifera & dogwood red-osier & $\begin{array}{l}\text { Wet Ground } \\
\text { Near Streams } \\
1700-2700 \mathrm{~m} \\
(5500-9000 \mathrm{ft})\end{array}$ \\
\hline Ericaceae & Arctostaphylos uva-ursi & bearberry & $\begin{array}{l}\text { Moist Woods } \\
2100-3000 \mathrm{~m} \\
(7000-10000 \mathrm{ft})\end{array}$ \\
\hline \multirow[t]{3}{*}{ Liliaceae } & Streptopus amplexifolius & twisted-stalk & $\begin{array}{l}\text { Damp Woods } \\
2100-3200 \mathrm{~m} \\
(8000-10500 \mathrm{ft})\end{array}$ \\
\hline & Lilium umbellatum & wood lily & $\begin{array}{l}\text { Open Woods } \\
2100-2400 \mathrm{~m} \\
(7000-8000 \mathrm{ft})\end{array}$ \\
\hline & Calochortus nuttallii & sego lily & $\begin{array}{l}\text { Open Slopes } \\
1500-2600 \mathrm{~m} \\
(5000-8500 \mathrm{ft})\end{array}$ \\
\hline
\end{tabular}




\section{APPENDIX B (cont)}

\begin{tabular}{|c|c|c|c|}
\hline Family & Species & Common Name & General Habit \\
\hline $\begin{array}{l}\text { Liliaceae } \\
\text { (continued) }\end{array}$ & $\underline{\text { Calochortus gunnisonii }}$ & mariposa lilly & $\begin{array}{l}\text { Meadows } \\
2100-2600 \mathrm{~m} \\
(7000-8500 \mathrm{ft})\end{array}$ \\
\hline Onagraceae & Epilobium angustifolium & fireweed & $\begin{array}{l}\text { Damp Clearings } \\
2100-3000 \mathrm{~m} \\
(7000-10000 \mathrm{ft})\end{array}$ \\
\hline \multirow[t]{7}{*}{ Orchidaceae } & Calypso bulbosa & fairy slipper & $\begin{array}{l}\text { Woods } \\
2100-2700 \mathrm{~m} \\
(6500-9000 \mathrm{ft})\end{array}$ \\
\hline & Corallorhiza maculata & spotted coralroot & $\begin{array}{l}\text { Woods } \\
2000-2700 \mathrm{~m} \\
(6500-9000 \mathrm{ft})\end{array}$ \\
\hline & Corallorhiza striata & striped coralroot & $\begin{array}{l}\text { Woods } \\
2000-2900 \mathrm{~m} \\
(6500-9500 \mathrm{ft})\end{array}$ \\
\hline & Epipactis gigantea & helleborine & $\begin{array}{l}\text { Damp Woods } \\
2100-2600 \mathrm{~m} \\
(7000-8500 \mathrm{ft})\end{array}$ \\
\hline & Goodvera oblongifolia & rattlesnake plantain & $\begin{array}{l}\text { Damp Woods } \\
2400-2900 \mathrm{~m} \\
(7500-9500 \mathrm{ft})\end{array}$ \\
\hline & Habenaria sparsiflora & bog orchid & $\begin{array}{l}\text { Moist Areas } \\
2300-2900 \mathrm{~m} \\
(7500-9500 \mathrm{ft})\end{array}$ \\
\hline & Malaxis soulei & adder's mouth & $\begin{array}{l}\text { Woods } \\
2400-2900 \mathrm{~m} \\
(8000-9500 \mathrm{ft})\end{array}$ \\
\hline Polemoniaceae & Ipomopsis & skyrocket & $\begin{array}{l}\text { Dry hills } \\
1500-2600 \mathrm{~m} \\
(5000-8500 \mathrm{ft})\end{array}$ \\
\hline
\end{tabular}




\begin{tabular}{|c|c|c|c|}
\hline Family & Species & Common Name & General Habit \\
\hline Primulaceae & $\begin{array}{l}\text { Dodecatheon pulchellum } \\
\text { Dodecatheon }\end{array}$ & shooting star & $\begin{array}{l}\text { Wet Meadow } \\
3300 \mathrm{~m} \\
(1100 \mathrm{ft})\end{array}$ \\
\hline \multirow[t]{7}{*}{ Ranunculaceae } & $\underline{\text { Aconitum }}$ & monkshood & $\begin{array}{l}\text { Moist Ground } \\
2300-3300 \mathrm{~m} \\
(7500-11000 \mathrm{ft})\end{array}$ \\
\hline & Aquilegia columbianum & $\begin{array}{l}\text { Rocky Mountain } \\
\text { columbine }\end{array}$ & $\begin{array}{l}\text { Woods and Meadows } \\
2100-3600 \mathrm{~m} \\
(7000-12000 \mathrm{ft})\end{array}$ \\
\hline & Aquilegia elegantula & red columbine & $\begin{array}{l}\text { Moist Woods } \\
2100-3000 \mathrm{~m} \\
(7000-10000 \mathrm{ft})\end{array}$ \\
\hline & Clematis drummondii & virgin's bower & $\begin{array}{l}\text { Slopes and Canyons } \\
1500 \mathrm{~m} \\
(5000 \mathrm{ft})\end{array}$ \\
\hline & Clematis ligusticifolia & $\begin{array}{l}\text { Western } \\
\text { virgin's bower }\end{array}$ & $\begin{array}{l}\text { Slopes and Canyons } \\
1200-2300 \mathrm{~m} \\
(4000-7500 \mathrm{ft})\end{array}$ \\
\hline & $\underline{\text { Clematis pseudoalpina }}$ & alpine clematis & $\begin{array}{l}\text { Woods } \\
2100-2700 \mathrm{~m} \\
(7000-9000 \mathrm{ft})\end{array}$ \\
\hline & $\underline{\text { Pulsatilla ludovician }}$ & pasqueflower & $\begin{array}{l}\text { Open Meadows } \\
2100-3000 \mathrm{~m} \\
(7000-10000 \mathrm{ft})\end{array}$ \\
\hline \multirow[t]{3}{*}{ Saxifragaceae } & Fendlera rupicola & fendlerbush & $\begin{array}{l}\text { Rocky Slopes } \\
1800-2100 \mathrm{~m} \\
(600-7000 \mathrm{ft})\end{array}$ \\
\hline & Heuchera parvifolia & alumroot & $\begin{array}{l}\text { Damp Woods and } \\
\text { Rocky Places } \\
2100-3200 \mathrm{~m} \\
(7000-1050 \mathrm{ft})\end{array}$ \\
\hline & $\underline{\text { Jamesia americana }}$ & cliffbrush & $\begin{array}{l}\text { Along Streams and } \\
\text { Canyon Walls } \\
2000-2700 \mathrm{~m} \\
(6000-9000 \mathrm{ft})\end{array}$ \\
\hline
\end{tabular}


APPENDIX B (cont)

\begin{tabular}{|c|c|c|c|}
\hline Family & Species & Common Name & General Habit \\
\hline \multirow[t]{6}{*}{$\begin{array}{l}\text { Saxifragaceae } \\
\text { (continued) }\end{array}$} & Philadelphus microphyllus & mock orange & $\begin{array}{l}\text { Rocky Hillsides } \\
\text { and Canyons } \\
2000-2900 \mathrm{~m} \\
(6500-9500 \mathrm{ft})\end{array}$ \\
\hline & Ribes cereum & wax currant & $\begin{array}{l}\text { Dry Slopes and } \\
\text { Ridges } \\
2100-2700 \mathrm{~m} \\
(6500-9000 \mathrm{ft})\end{array}$ \\
\hline & Ribes lepthanthum & trumpet gooseberry & $\begin{array}{l}\text { Canyons and Woods } \\
2300-3300 \mathrm{~m} \\
(7500-11000 \mathrm{ft})\end{array}$ \\
\hline & Ribes montigenum & gooseberry currant & $\begin{array}{l}\text { Woods } \\
2100-2700 \mathrm{~m} \\
(7000-9000 \mathrm{ft})\end{array}$ \\
\hline & Ribes inerme & whitestem gooseberry & $\begin{array}{l}\text { Moist Ground } \\
2100-2600 \mathrm{~m} \\
(7000-13000 \mathrm{ft})\end{array}$ \\
\hline & Saxifraga rhomboidea & saxifrage & $\begin{array}{l}\text { Moist Ground } \\
2100-3600 \mathrm{~m} \\
(7000-13000 \mathrm{ft})\end{array}$ \\
\hline Scrophulariaceae & Castilla integra & Indian paintbrush & $\begin{array}{l}\text { Dry Slopes } \\
1400-2300 \mathrm{~m} \\
(4500-7500 \mathrm{ft})\end{array}$ \\
\hline
\end{tabular}


TABLE C-I

MAMMALS

Cervidae

Odocoileus

hemionus

Cervus

canadensis

Erethizontidae

Erethizon

dorsatum

Sciuridae

Tamiasciurus

hudsonicus

Sciurus aberti

Spermophilus

variegatus

Spermophilus

spilosoma

Spermophilus

lateralis

Eutamias

dorsalis

Eutamias

guadrivittatus

Eutamias

minimus

Cynomys gunnisoni

Leporidae

Sylvilagus

nuttallii

Lepus

Californicus

Ochotonidae

Ochotona

princeps

Muridae

Mus musculus

Heteromidae

Dipodomys ordii

Perognathus

flavus

Cricetidae

Peromyscus

leucopus

Peromyscus

maniucles

Peromyscus

bovlii

Peromyscus

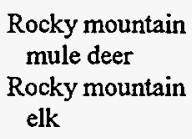

elk

Porcupine

Red squirrel

Tassel-eared

squirrel

Rock squirrel

Spotted ground

squirrel

Golden mantled

ground squirrel

Cliff chipmunk

Colorado chipmunk

Least chipmunk

White-tailed

priarie dog

Mountain

cottontail

Black-tailed

jackrabbit

Pika

House mouse

Ord's kangaroo

rat

Silky pocket

mouse

White-footed

mouse

Deer mouse

Brush mouse

Pinon mouse

\begin{tabular}{ccc}
$\begin{array}{c}\text { Verified } \\
\text { to Be } \\
\text { in Area }\end{array}$ & $\begin{array}{c}\text { Presence } \\
\text { Reported or } \\
\text { Suspected }\end{array}$ & $\begin{array}{c}\text { Threatened }^{\mathrm{a}} \\
\text { or } \\
\text { Endangered }\end{array}$ \\
\hline
\end{tabular}

$\mathrm{x}$

$\mathbf{x}$

x

$\mathrm{x}$

x

$\mathbf{x}$

$\mathrm{x}$

$\mathrm{x}$

x

$\mathbf{x}$

$x$

$x$

$\mathrm{x}$

$\mathrm{x}$

$\mathrm{x}$

$x$

$\mathrm{x}$

$\mathrm{x}$

$\mathrm{x}$

$\mathbf{x}$

$\mathrm{x}$

$\mathbf{x}$

true

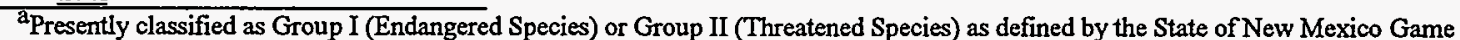
Commission Regulation No. 563, as adopted January 24, 1975. 
TABLE C-I (cont)

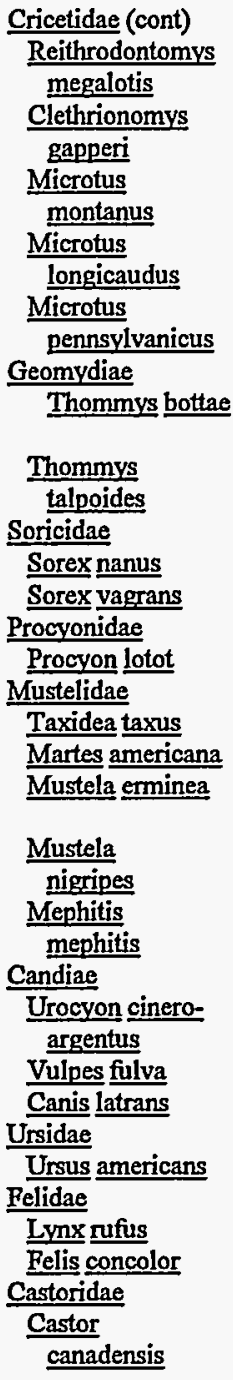

Westem harvest

mouse

Gappers red-

backed vole

Montane vole

Long-tailed vole

Meadow vole

Valley pocket

gopher

Northern pocket

gopher

Dwarf shrew

Vagrant shrew

Raccoon

American badger

Pine marten

Ermine/Short-tail

weasel

Black-footed

ferret

Striped skunk

Gray fox

Red fox

Coyote

Balck bear

Bobcat

Mountain lion

Beaver
Threatened ${ }^{\mathrm{a}}$

or

Endangered x

$x$

$\mathrm{x}$

$\mathrm{x}$

$\mathrm{x}$

$\mathrm{x}$

$x$

$x$

$\mathbf{x}$

$x$

$\mathbf{x}$

x $\mathbf{x}$

x

x

$\mathrm{x}$

$x$

$\mathbf{x}$
$\mathbf{x}$
Suspected 
TABLE C-II

AMPHIBIANS AND REPTILES

Plethodontidae

Plethodon

neomexicanus

Teidae

Chemidophorus spp.

Iguanidae

Phyrynosoma spp.

Crotaphytus

collaris

Sceloporus

magister

Viperidae

Crotalus

viridis

Colubridae

Pituophis

melanoleucas

Thamnophis

sirtalis

Thamnophis

elegans

Lampropeltis

getulus
Jemez Mountain salamander

Whiptail

Horned lizard

Collared lizard

Desert spiny

lizard

Prairie rattlesnake

Bull snake

Common garter

snake

Western garter

snake

Common king

snake

\begin{tabular}{ccc}
$\begin{array}{c}\text { Verified } \\
\text { to Be } \\
\text { in Area }\end{array}$ & $\begin{array}{c}\text { Presence } \\
\text { Reported or } \\
\text { Suspected }\end{array}$ & $\begin{array}{c}\text { Threatened }^{\mathrm{a}} \\
\text { or } \\
\text { Endangered }\end{array}$ \\
\hline
\end{tabular}

$\mathrm{x}$

$\mathrm{x}$

$\mathrm{x}$

$\mathrm{x}$

$\mathbf{x}$

$\mathrm{x}$

$\mathrm{x}$

$\mathrm{x}$

$\mathrm{x}$

$\mathrm{x}$

$\mathrm{x}$

TABLE C-III

FISH

\begin{tabular}{ccc}
$\begin{array}{c}\text { Verified } \\
\text { to Be } \\
\text { in Area }\end{array}$ & $\begin{array}{c}\text { Presence } \\
\text { Reported or } \\
\text { Suspected }\end{array}$ & $\begin{array}{c}\text { Threatened }^{\mathrm{a}} \\
\text { or } \\
\text { Endangered }\end{array}$ \\
\hline
\end{tabular}

\section{Catostomidae}

Catostomus

commersomi

Carpoides carpio

Cyprinidae

Cyrinus carpio

Hybopsis spp.

Salmonidae

$\underline{\text { Salmo trutta }}$

White sucker

Carp-sucker

Carp

Chub

Brown trout $\mathrm{x}$

$\mathrm{X}$

$\mathrm{x}$

$\mathrm{x}$

$\mathrm{x}$ 
Gaviiformes

Gavia immer

Podicipiformes

Podicep caspicus

Anseriformes

Branta canadensis

Anas platyrhychos

Anas strepera

Anas acuta

Anas carolinensis

Anas discors

Anas ctanopters

Marcea americana

Spatula clypeata

Aythya collaris

Aythya affinis

Bucephala albeola

Oxyura jamaicensis

Mergus merganser

Falconiformes

Cathartes aura

Accipiter gentilis

Accipiter striatus

Accipiter cooperii

Buteo ja,aicensis

Buteo albonotatus

Buteo lagopus

Buteo regalis

Aquila chrysaetos

Circus cyaneus

Pandion haliaetus

Palco mexicanus

Falco peregrinus

Palco columbarius

Palco sparverius

\section{Galliformes}

Dendragapus

obscurus

Callipepla

squqmata

Lophortyx gambelii

Melagris gallopavo

Common loon

Eared grebe

Canada goose

Mallard

Gadwall

Pintail

Green-winged teal

Blue-winged teal

Cinnamon teal

American widgeon

Shoveler

Ring-necked duck

Lesser scaup

Bufflehead

Ruddy duck

Common merganser

Turkey vulture

Goshawk

Sharp-shinned hawk

Cooper's hawk

Red-tailed hawk

Zone-tailed hawk ${ }^{b}$

Rough-legged hawk

Ferruginous hawk ${ }^{b}$

Golden eagle

Marsh hawk

Osprey $^{b}$

Prairie falcon ${ }^{b}$

Peregrine falcon ${ }^{b}$

Merlin (pigeon hawk)

American kestrel

Blue grouse

Scaled quail

Gamble's quail

Wild turkey
TABLE C-IV

BIRDS

Nest

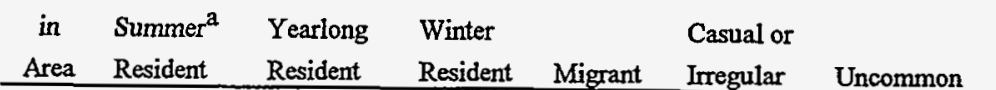

$x$

$\mathbf{x}$

$\mathrm{x}$

$\mathbf{x}$

$\mathbf{x}$

$\mathbf{x}$

$\mathbf{x}$

$\mathbf{x}$

$\mathbf{x}$

$\mathrm{x}$

$\mathrm{x}$

$\mathbf{x}$

$\mathrm{x}$

$x$

$\mathbf{x}$

$x$

This category only covers summer residents that nest in the area. Clearly yearlong residents also nest in the area.

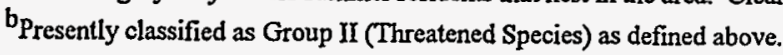


Gruiformes

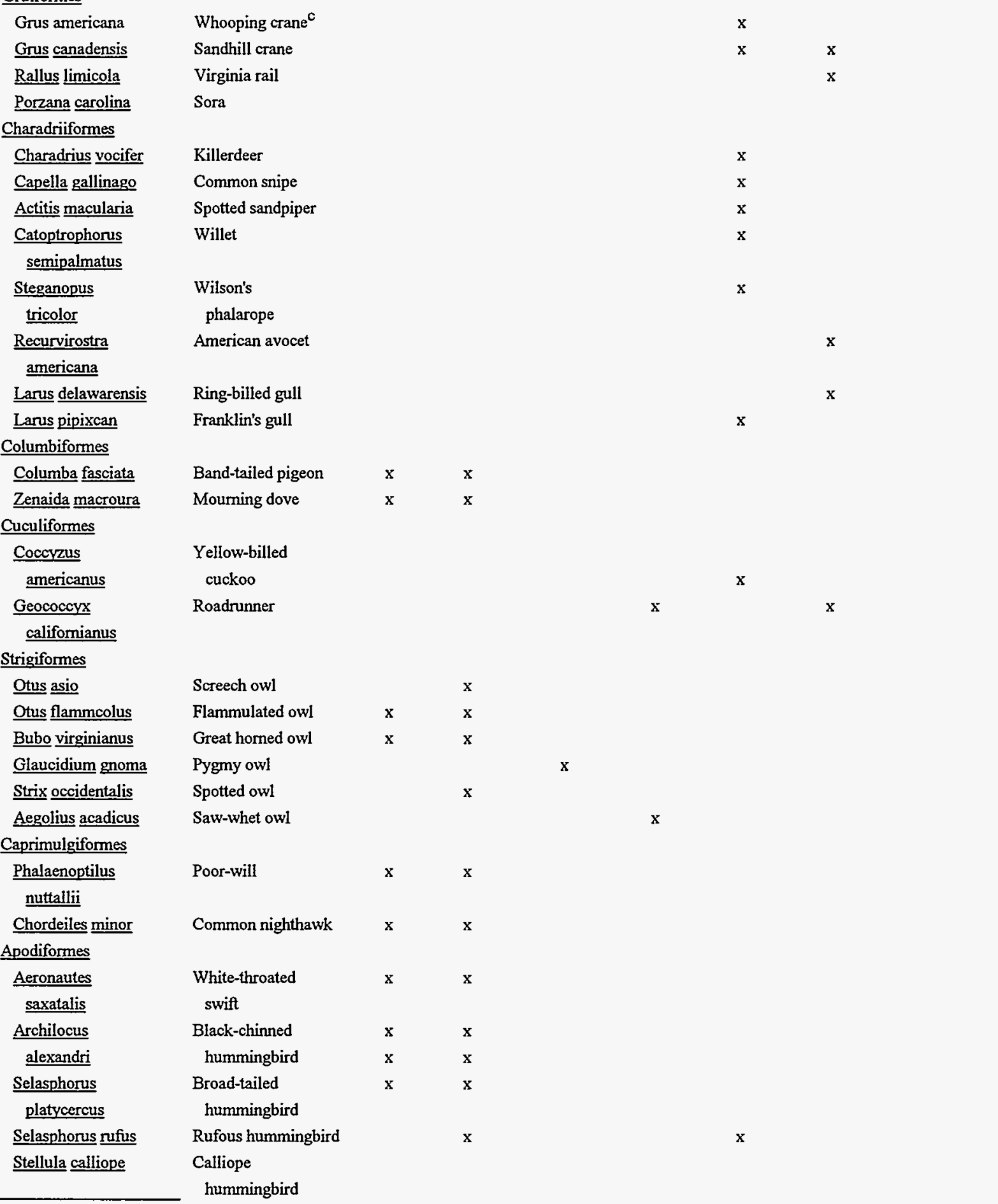

${ }^{c}$ Presently classified as Group I (Endangered Species) as defined by the State of New Mexico Game Commission Regulation No. 563, as adopted January 24, 1975. 
TABLE C-IV (cont)

Nest

\begin{tabular}{ccccccc} 
in & Summer $^{\mathbf{a}}$ & Yearlong & Winter & Casual or \\
Area & Resident & Resident & Resident & Migrant & Irregular & Uncommon \\
\hline
\end{tabular}

Piciformes

Colaptes auratus

Melanerpes

formicivons

Melanerpes

ervthrocephalus

Spyrapicus

varius

Spyrapicus throideus

Dendrocopos villosus

Dendrocopo

pubescens

Dendrocopos

scalaris

Asyndesmus lewis

Passeriformes

Tryannus vociferans

Myiarchus

cinerascens

Sayornis saya

Empidonax traillii

Empidonas

hammondii

Empidonax oberholseri

Empidonax wrightii

Empidonax difficillis

Contopus sordidulus

Nuttallomis

borealis

Eremophila alpestris

Tachycineta thalassina

Iridoprocne bicolor

Cyanocitt cristata

Cyanocitta stelleri

Aphelocoma

coerulescens

Corvus corax

Corvus brachyrhynchos

Nucifraga

columbiana

Gymnorhinus

cyanocephalus
Common flicker

Acorn woodpecker

Red-headed

wooodpecker ${ }^{b}$

Yellow-bellied

sapsucker

Williamson's sapsucker $\mathrm{x}$

Hairy Woodpecker

Downy

woodpecker

Ladder-backed

woodpecker

Lewis' woodpecker

Cassin's kingbird

Ash-throated

flycatcher

Say's phoebe

Traili's flycatcher

Hammond's

flycatcher

Dusky flycatcher

Gray flycatcher

Western flycatcher

Western wood pewee

Olive-sided

flycatcher

Horned lark

Violet-green swallow

Tree swallow

Blue jay

Steller's jay

Scrub jay

Common raven

Common crow

Clark's

nutcracker

Pinon jay $\mathrm{x}$

$\mathrm{x}$

$\mathrm{x}$

$x$

x $\quad \mathrm{x}$

$x$ 


\begin{tabular}{|c|c|c|c|c|c|c|c|c|}
\hline & & $\begin{array}{c}\text { Nest } \\
\text { in } \\
\text { Area }\end{array}$ & $\begin{array}{l}\text { Summer }^{\mathbf{a}} \\
\text { Resident }\end{array}$ & $\begin{array}{l}\text { Yearlong } \\
\text { Resident }\end{array}$ & $\begin{array}{l}\text { Winter } \\
\text { Resident }\end{array}$ & Migrant & $\begin{array}{l}\text { Casual or } \\
\text { Irregular }\end{array}$ & Uncommon \\
\hline Passerformes (cont.) & & & & & & & & \\
\hline$\frac{\underline{\text { Parus }}}{\text { atricappillus }}$ & $\begin{array}{c}\text { Black-capped } \\
\text { chickadee }\end{array}$ & & & & & $\mathrm{x}$ & & \\
\hline Parus gambelli & Mountain chickadee & & & $\mathrm{x}$ & & & & \\
\hline Parus inornatus & Plain titmouse & & & $\mathrm{x}$ & & & & \\
\hline Psalriparus minimus & Common bushtit & & & & & $\mathrm{x}$ & & \\
\hline $\begin{array}{l}\underline{\text { Sitta }} \\
\text { carolinensis }\end{array}$ & $\begin{array}{l}\text { White-breasted } \\
\text { nuthatch }\end{array}$ & & & $\mathrm{x}$ & & & & \\
\hline $\begin{array}{l}\text { Sitta } \\
\text { canadensis }\end{array}$ & $\begin{array}{l}\text { Red-breasted } \\
\text { nuthatch }\end{array}$ & & & & $x$ & & & \\
\hline $\begin{array}{l}\frac{\text { Certhia }}{\text { familiaris }} \\
\text {. }\end{array}$ & Brown creeper & & & & $x$ & $\mathrm{x}$ & & \\
\hline$\frac{\underline{\text { Sitta }}}{\text { pygmea }}$ & Pygmy nuthatch & & & $\mathrm{x}$ & & & & \\
\hline$\underline{\text { Cinclus mexicanus }}$ & Dipper & & & & & & $x$ & \\
\hline$\frac{\text { Troglodvtes }}{\underline{\text { aedon }}}$ & House wren & & $\mathrm{x}$ & & & & & \\
\hline$\frac{\text { Catherpes }}{\text { mexicanus }}$ & Canyon wren & $\mathbf{x}$ & $\mathrm{x}$ & & & & & \\
\hline$\frac{\text { Salpinctes }}{\text { obsoletus }}$ & Rock wren & $x$ & & $\mathrm{x}$ & & & & \\
\hline$\frac{\text { Dumetella }}{\text { carolinensis }}$ & Catbird & & & & & $\mathbf{x}$ & & \\
\hline$\frac{\text { Toxostoma }}{\text { rufum }}$ & $\begin{array}{l}\text { Brown } \\
\text { thrasher }\end{array}$ & & & & $\mathrm{x}$ & & & \\
\hline$\frac{\text { Oreoscoptes }}{\text { montanus }}$ & Sage thrasher & & & & $\mathrm{x}$ & & & \\
\hline$\frac{\text { Turdus }}{\underline{\text { migratorius }}}$ & Robin & & & $x$ & & & & \\
\hline$\frac{\text { Hylocichla }}{\text { guttata }}$ & $\begin{array}{l}\text { Hermit } \\
\text { thrush }\end{array}$ & & $x$ & & & & & \\
\hline$\frac{\text { Hylochichla }}{\text { ustulata }}$ & $\begin{array}{l}\text { Swainson's } \\
\text { thrush }\end{array}$ & & $x$ & & & & $x$ & \\
\hline$\frac{\underline{\text { Seiurus }}}{\text { noveboracenis }}$ & $\begin{array}{l}\text { Northern } \\
\text { waterthrush }\end{array}$ & & & & & & & \\
\hline Sialia & Western & & & $\mathrm{x}$ & & & & \\
\hline mexicana & bluebird & & & $\mathrm{x}$ & & & & \\
\hline$\underline{\text { Sialia }}$ & Mountain & & & $x$ & & & & \\
\hline currucoides & bluebrid & & & $\mathrm{x}$ & & & & \\
\hline$\frac{\text { Myadestes }}{\underline{\text { townsendi }}}$ & $\begin{array}{l}\text { Townsend's } \\
\text { solitaire }\end{array}$ & & & $\mathrm{x}$ & & & & \\
\hline$\frac{\text { Polioptila }}{\text { caerulea }}$ & $\begin{array}{l}\text { Blue-gray } \\
\text { gnatcatcher }\end{array}$ & & $\mathrm{x}$ & & & & & \\
\hline$\frac{\text { Regulus }}{\text { satrapa }}$ & $\begin{array}{l}\text { Golden-crowned } \\
\text { kinglet }\end{array}$ & & & $x$ & & & & \\
\hline
\end{tabular}




\begin{tabular}{|c|c|c|c|c|c|c|c|c|}
\hline & & $\begin{array}{c}\text { Nest } \\
\text { in } \\
\text { Area }\end{array}$ & $\begin{array}{l}\text { TABLE C } \\
\text { Summer }^{a} \\
\text { Resident } \\
\end{array}$ & $\begin{array}{l}\text { Yearlong } \\
\text { Resident }\end{array}$ & $\begin{array}{l}\text { Winter } \\
\text { Resident } \\
\end{array}$ & Migrant & $\begin{array}{l}\text { Casual or } \\
\text { Irregular }\end{array}$ & Uncommon \\
\hline Passerformes (cont.) & & & & & & & & \\
\hline$\frac{\text { Regulus }}{\text { calendula }}$ & $\begin{array}{l}\text { Ruby-crowned } \\
\text { kinglet }\end{array}$ & & & $\mathrm{x}$ & & & & \\
\hline Anthus spinoletta & Water pipit & & & & & $x$ & & \\
\hline Bombycilla garrulus & Bohemian waxwing & & & & $\mathrm{x}$ & & & \\
\hline$\frac{\text { Bobmycilla }}{\text { cedrorum }}$ & $\begin{array}{l}\text { Cedar } \\
\text { waxwing }\end{array}$ & & & & $\mathrm{x}$ & & & \\
\hline Lanius excubitor & Northern shrike & & & & $x$ & & & \\
\hline $\begin{array}{l}\frac{\text { Lanius }}{\underline{\text { Ludovicianus }}} \\
\underline{\underline{4}}\end{array}$ & $\begin{array}{l}\text { Loggerhead } \\
\text { shrike }\end{array}$ & & & $x$ & & & & \\
\hline Sturnus vulgaris & Starling & & & $\mathrm{x}$ & & & & \\
\hline Vireo solitarius & Solitary vireo & $\mathrm{x}$ & $\mathrm{x}$ & & & & $\mathbf{x}$ & \\
\hline Vireo olivaceus & Red-eyed vireo & & & & & & & \\
\hline Vireo gilvus & Warbling vireo & & & & & $x$ & & \\
\hline$\frac{\text { Vermivora }}{\text { celata }}$ & $\begin{array}{l}\text { Orange-crowned } \\
\text { warbler }\end{array}$ & & & & & $x$ & & \\
\hline$\frac{\text { Vermivora }}{\text { nuficappila }}$ & $\begin{array}{r}\text { Nashville } \\
\text { warbler }\end{array}$ & & & & & $\mathrm{x}$ & & \\
\hline$\frac{\text { Vermivora }}{\text { virginiae }}$ & $\begin{array}{r}\text { Virginia's } \\
\text { warbler }\end{array}$ & $x$ & $x$ & & & & & \\
\hline$\frac{\text { Dendroica }}{\text { petchia }}$ & $\begin{array}{l}\text { Yellow } \\
\text { warbler }\end{array}$ & & & & & & & \\
\hline $\begin{array}{l}\text { Dendroica } \\
\text { caerulescens }\end{array}$ & $\begin{array}{c}\text { Black-throated } \\
\text { blue warbler }\end{array}$ & & & & & & & \\
\hline$\frac{\text { Dendroica }}{\text { coronata }}$ & $\begin{array}{l}\text { Yellow-rumped } \\
\text { warbler }\end{array}$ & & & $x$ & & & & \\
\hline$\frac{\text { Dendroica }}{\text { nigrescens }}$ & $\begin{array}{l}\text { Black-throated } \\
\text { gray warbler }\end{array}$ & & $\mathbf{x}$ & & & & & \\
\hline $\begin{array}{l}\text { Dendroica } \\
\text { townsendi }\end{array}$ & $\begin{array}{l}\text { Townsend's } \\
\text { warbler }\end{array}$ & & & & & & & \\
\hline$\frac{\text { Dendroica }}{\text { virens }}$ & $\begin{array}{l}\text { Black-throated } \\
\text { green warbler }\end{array}$ & & & & & $\mathrm{x}$ & $x$ & \\
\hline$\frac{\text { Dendroica }}{\text { graciae }}$ & $\begin{array}{l}\text { Grace's } \\
\text { warbler }\end{array}$ & & $\mathbf{x}$ & & & & & \\
\hline$\frac{\text { Dendroica }}{\text { pennsylvania }}$ & $\begin{array}{l}\text { Chestnut-sided } \\
\text { warbler }\end{array}$ & & & & & & $\mathrm{x}$ & \\
\hline$\frac{\text { Oporornis }}{\text { tolmiei }}$ & $\begin{array}{l}\text { MacGillivray's } \\
\text { warbler }\end{array}$ & & & & & & $x$ & \\
\hline$\frac{\text { Icteria }}{\text { virens }}$ & $\begin{array}{l}\text { Yellow-breasted } \\
\text { chat }\end{array}$ & & & & & $\mathbf{x}$ & & \\
\hline$\frac{\text { Wilsonia }}{\text { pusilla }}$ & $\begin{array}{l}\text { Wilson's } \\
\text { warbler }\end{array}$ & & & & & $x$ & & \\
\hline
\end{tabular}




\begin{tabular}{|c|c|c|c|c|c|c|c|c|}
\hline \multirow{2}{*}{\multicolumn{9}{|c|}{ Passerformes (cont) }} \\
\hline & & & & & & & & \\
\hline $\begin{array}{l}\text { Setophaga } \\
\underline{\text { ruticilla }}\end{array}$ & $\begin{array}{c}\text { American } \\
\text { redstart }\end{array}$ & & & & & $x$ & & \\
\hline$\frac{\text { Passer }}{\text { domesticus }}$ & $\begin{array}{l}\text { House } \\
\text { sparrow }\end{array}$ & & & $\mathrm{x}$ & & & & \\
\hline$\frac{\text { Sturnella }}{\underline{\text { neglecta }}}$ & $\begin{array}{l}\text { Weastern } \\
\text { meadowlark }\end{array}$ & & & & & & $x$ & \\
\hline$\frac{\text { Xanthocephalus }}{\text { zanthocephalus }}$ & $\begin{array}{l}\text { Yellow-headed } \\
\text { blackbird }\end{array}$ & & & & & $x$ & & \\
\hline$\frac{\text { Agelaius }}{\text { phoeniceous }}$ & $\begin{array}{l}\text { Red-winged } \\
\text { blackbird }\end{array}$ & & & & & $x$ & & \\
\hline$\frac{\text { Icterus }}{\text { bullockii }}$ & $\begin{array}{l}\text { Bullock's } \\
\text { oriole }\end{array}$ & & $\mathrm{x}$ & & & & & \\
\hline$\frac{\text { Euphagus }}{\text { carolinus }}$ & $\begin{array}{l}\text { Rusty } \\
\text { blackbird }\end{array}$ & & & & & & $x$ & \\
\hline$\frac{\text { Euphagus }}{\text { cyancephalus }}$ & $\begin{array}{l}\text { Brewer's } \\
\text { blackbird }\end{array}$ & $\mathrm{x}$ & $\mathrm{x}$ & & & & & \\
\hline$\frac{\text { Quiscalus }}{\text { quiscula }}$ & $\begin{array}{r}\text { Common } \\
\text { grackle }\end{array}$ & & $\mathrm{x}$ & & & & & \\
\hline$\frac{\text { Molothrus }}{\underline{\text { ater }}}$ & $\begin{array}{l}\text { Brown-headed } \\
\text { cowbird }\end{array}$ & & $x$ & & & & & \\
\hline$\frac{\text { Piranga }}{\text { flava }}$ & $\begin{array}{l}\text { Hepatic } \\
\text { tanager }\end{array}$ & & $\mathrm{x}$ & & & & & \\
\hline $\begin{array}{l}\text { Piranga } \\
\text { rubra }\end{array}$ & $\begin{array}{l}\text { Summer } \\
\text { tanager }\end{array}$ & $\mathrm{x}$ & $\mathrm{x}$ & & & & & \\
\hline $\begin{array}{l}\text { Pheucticus } \\
\text { ludovicianus }\end{array}$ & $\begin{array}{c}\text { Rose-breasted } \\
\text { grosbeak }\end{array}$ & $x$ & & & & & $x$ & \\
\hline$\frac{\text { Pheucticus }}{\text { melanocephalus }}$ & $\begin{array}{c}\text { Black-headed } \\
\text { grosbeak }\end{array}$ & & $\mathrm{x}$ & & & & & \\
\hline $\begin{array}{l}\text { Guiraca } \\
\text { caerulea }\end{array}$ & $\begin{array}{l}\text { Blue } \\
\text { grosbeak }\end{array}$ & & $\mathbf{x}$ & & & & & \\
\hline$\frac{\text { Passerina }}{\text { cyanea }}$ & $\begin{array}{l}\text { Indigo } \\
\text { bunting }\end{array}$ & & & & & $\mathrm{x}$ & & \\
\hline$\frac{\text { Passerina }}{\text { amoena }}$ & $\begin{array}{l}\text { Lazuli } \\
\text { bunting }\end{array}$ & & $\mathrm{x}$ & & & & & \\
\hline$\frac{\text { Hesperiphona }}{\text { vespertina }}$ & $\begin{array}{l}\text { Evening } \\
\text { grosbeak }\end{array}$ & & & $\mathbf{x}$ & & & & \\
\hline$\frac{\text { Carpodacus }}{\text { cassinii }}$ & $\begin{array}{l}\text { Cassin's } \\
\text { finch }\end{array}$ & & $x$ & & & & & \\
\hline$\frac{\text { Carpodacus }}{\text { mexicanus }}$ & $\begin{array}{r}\text { House } \\
\text { finch }\end{array}$ & & & $x$ & & & & \\
\hline$\frac{\underbrace{}_{\text {enucleator }}}{\text { encola }}$ & $\begin{array}{l}\text { Pine } \\
\text { grosbeak }\end{array}$ & & & & & $\mathrm{x}$ & & \\
\hline$\frac{\text { Leucosticte }}{\text { tephrocotis }}$ & $\begin{array}{l}\text { Gray-crowned } \\
\text { rosy finch }\end{array}$ & & & & & $x$ & & \\
\hline Spinus pinus & Pine siskin & $x$ & $\mathrm{x}$ & & & & & \\
\hline
\end{tabular}




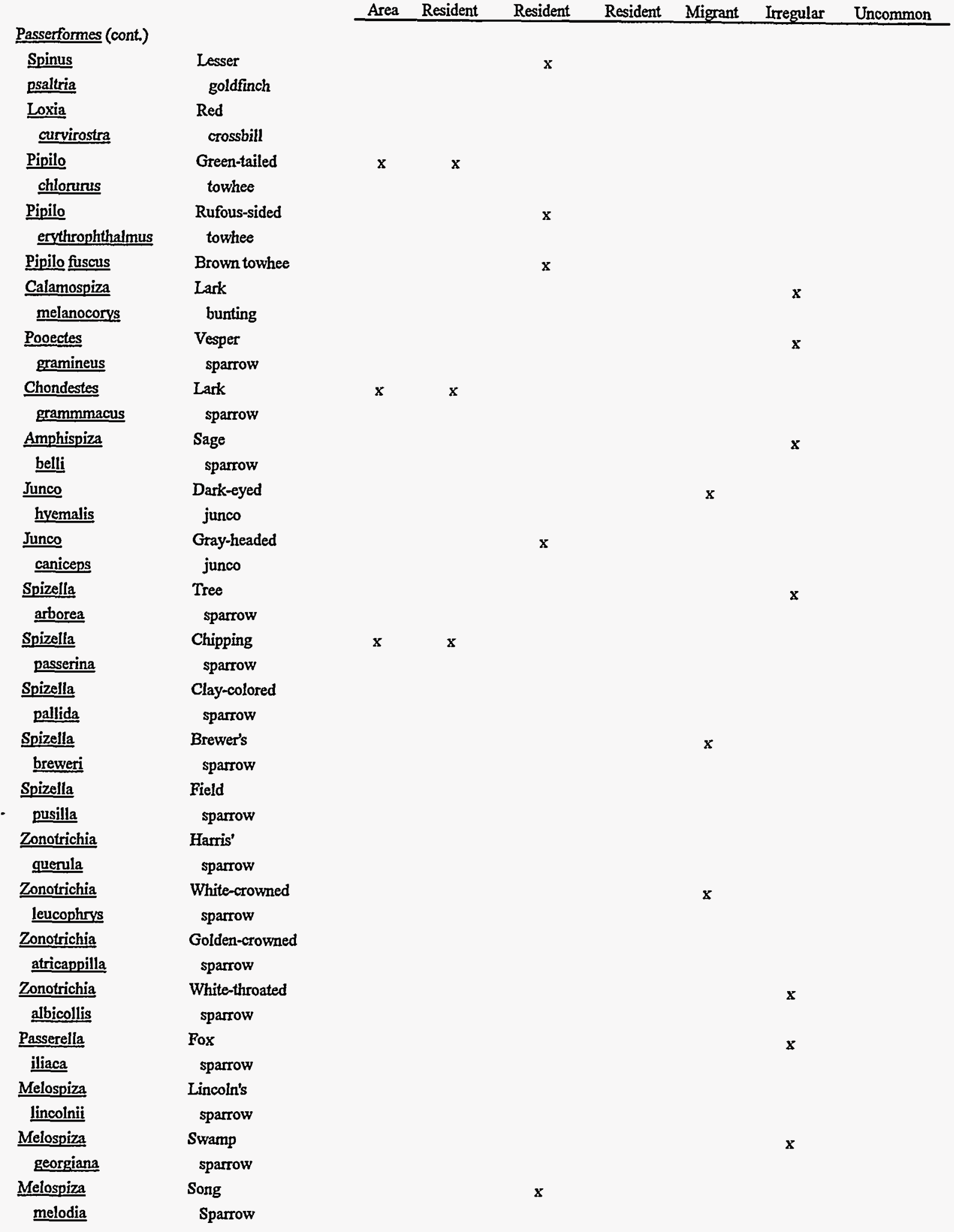


TABLE C-V

INVERTEBRATES

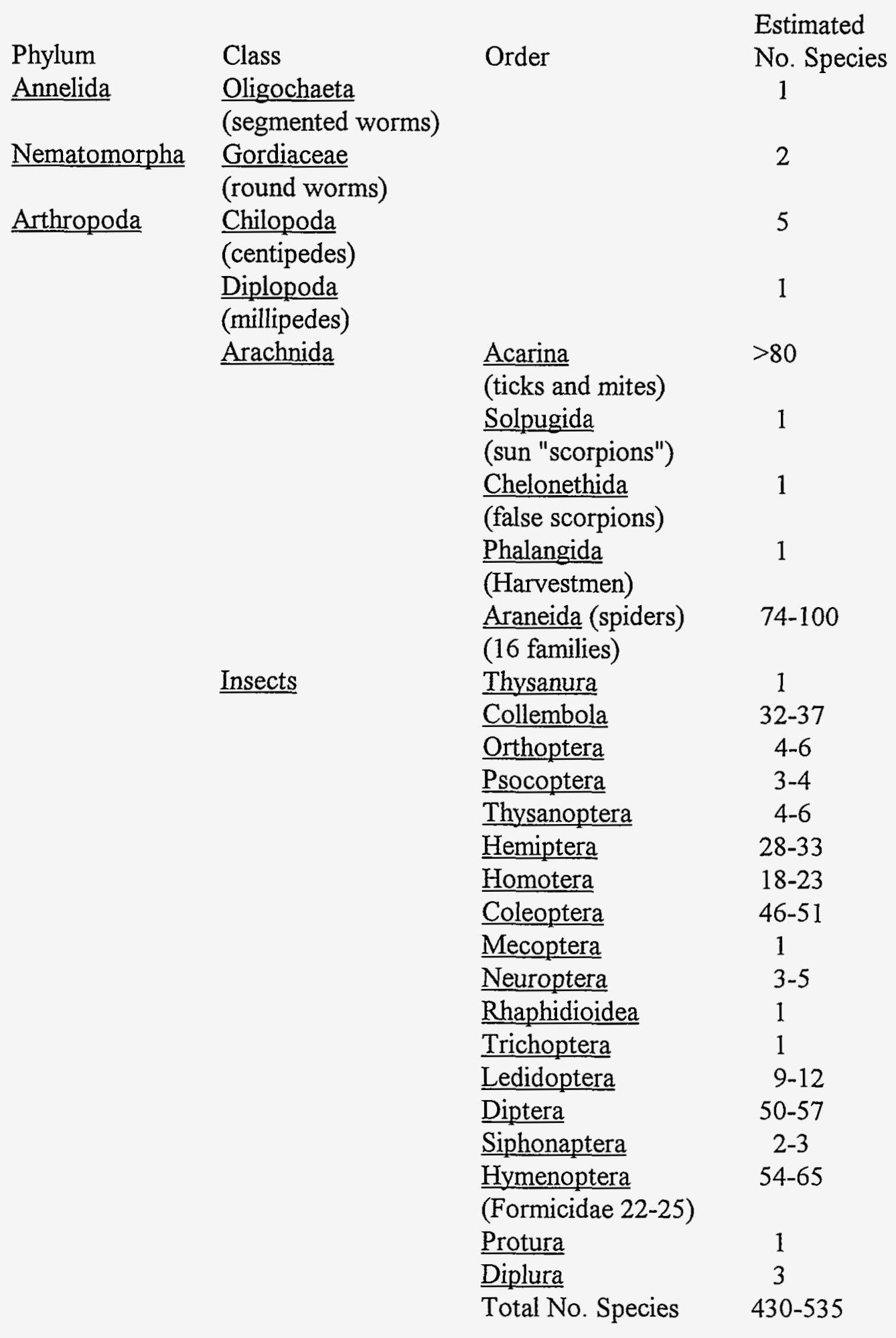




\section{APPENDIX D}

\section{DOSE CALCULATIONS FOR LOWER PUEBLO CANYON/LOWER LOS ALAMOS CANYON}

\subsection{SOIL CONCENTRATIONS IN THE AREAS OF CLEANUP}

Soil and sediment sampling data were taken during radiogical surveys of Pueblo Canyon and lower Los Alamos Canyon and published in Ref. Dl. These data form the basis of the majority of the dose calculations presented in this appendix.

For convenience, the canyon system was divided into four sections: Acid Canyon, middle Pueblo Canyon, lower Pueblo Canyon, and lower Los Alamos Canyon. Average radionuclide concentrations were calculated for the active channel, inactive channel (where applicable), and bank areas for ${ }^{90} \mathrm{Sr},{ }^{137} \mathrm{Cs},{ }^{234} \mathrm{U}$ and ${ }^{239,240} \mathrm{Pu}$. The ${ }^{238} \mathrm{Pu},{ }^{241} \mathrm{Pu}$, and ${ }^{241} \mathrm{Am}$ concentrations were derived from the $239,240 \mathrm{Pu}$ values using measured isotopic rations. The soil and sediment data are presented in Tables D-XII, D-XIV, D-XVIII, D-XX, E, IV, E-V, and E-VII of Ref. Dl. The average concentrations upon which dose calculations are based are summarized in Table D-I.

\subsection{OCCUPATIONAL EXPOSURES}

Alternatives I and II both involve some exposure of workers to the contaminated soil in the canyon system. This section describes how doses to those workers were estimated.

\subsection{Doses to Cleanup Workers}

Cleanup workers would receive the majority of their radiation doses through inhalation and through exposure to external radiation. The principal dose results from inhalation of soil mechanically resuspended by heavy machinery in the decontamination operation. Abovebackground external exposure is mainly caused from the trace amounts of gamma-ray emitting radionuclides, such as ${ }^{137} \mathrm{CS}$, present in the soil. 
TABLE D-I

SOIL AND SEDIMENT CONCENTRATIONS USED IN DOSE CALCULATIONS

Soil/Sediment Concentrations (pCi/g)

\begin{tabular}{llllllll} 
Channel Section & ${ }^{90} \mathrm{Sr}$ & ${ }^{137} \mathrm{Cs}$ & $234 \mathrm{U}$ & $238 \mathrm{Pu}$ & $239,240 \mathrm{Pu}$ & $241_{\mathrm{Pu}}$ & $241_{\mathrm{Am}}$ \\
\hline Acid & & & & & & & \\
$\quad$ Active Channel & $1.5 \pm 1.6$ & $2.8 \pm 4.6$ & $17 \pm 12$ & 0.98 & $30.6 \pm 29.4$ & 23 & 1.7 \\
$\quad$ Banks & $0.51 \pm 0.39$ & $0.65 \pm 0.57$ & - & 3.5 & $110 \pm 75$ & 84 & 5.9 \\
Middle Pueblo & & & & & & & \\
$\quad$ Active Channel & $0.47 \pm 0.35$ & $0.34 \pm 0.13$ & - & 0.035 & $1.10 \pm 1.10$ & 0.84 & 0.23 \\
$\quad$ Banks & $0.48 \pm 0.24$ & $0.44 \pm 0.27$ & $4.7 \pm 1.2$ & 0.11 & $3.48 \pm 4.0$ & 2.6 & 0.73 \\
Lower Pueblo & & & & & & & \\
$\quad$ Active Channel & $0.18 \pm 0.08$ & $0.104 \pm 0.086$ & $4.0 \pm 2.0$ & 0.028 & $0.86 \pm 0.54$ & 0.65 & 0.18 \\
Inactive Channel & $0.38 \pm 0.21$ & $0.52 \pm 0.44$ & $11.7 \pm 4.3$ & 0.16 & $5.05 \pm 3.60$ & 3.8 & 1.1 \\
Banks & $0.52 \pm 0.31$ & $0.73 \pm 0.65$ & $9.7 \pm 1.6$ & 0.21 & $6.43 \pm 5.77$ & 4.9 & 1.4 \\
Low Los Alamos & & & & & & & \\
Active Channel & $0.15 \pm 0.10$ & $0.39 \pm 0.36$ & $12.5 \pm 3.9$ & 0.0077 & $0.24 \pm 0.26$ & 0.18 & 0.050 \\
Inactive Channel & $0.28 \pm 0.12$ & $0.45 \pm 0.37$ & $13.6 \pm 4.4$ & 0.0048 & $0.15 \pm 0.18$ & 0.11 & 0.032 \\
Banks & $0.45 \pm 0.21$ & $1.04 \pm 0.73$ & $18.0 \pm 5.4$ & 0.075 & $2.34 \pm 2.98$ & 1.8 & 0.49 \\
Background & $0.25 \pm 0.27$ & $0.32 \pm 0.30$ & $0.60 \pm 0.43$ & & & &
\end{tabular}


Inhalation doses were calculated using the formula

$D_{i j}=(T S P)\left(C_{j}\right)(E F)(B R)(T)\left(D F_{i j}\right)$

for 50-year commitments where

$D_{i j}=50$-year dose commitment received by organ i from radionuclide $j$ (mrem),

TSP $=$ total suspended particulates or mass loading; the amount of dust in the air $\left(\mathrm{g} / \mathrm{m}^{3}\right)$

$\mathrm{C}_{\mathrm{j}}=$ soil concentration of radionuclide $\mathrm{j}(\mathrm{pCi} / \mathrm{g})$,

$\mathrm{EF}=$ enrichment factor

$\mathrm{BR}=0.043 \mathrm{~m}^{3} / \mathrm{min}$, the breathing rate typical of an adult doing heavy work (Ref. D2),

$\mathrm{T}=$ the estimated length of time needed for cleanup (site preparation and excavation) of the area, and

$\mathrm{DCF}_{\mathrm{ij}}=$ dose conversion factor giving the 50 -yr dose commitment (mrem) to organs caused from inhalation of $1 \mathrm{pCi}$ of radionuclide $\mathrm{j}(\mathrm{mrem} / \mathrm{pci})$.

The value of TSP was assumed to be $5000 \mu \mathrm{g} / \mathrm{m}^{3}\left(0.005 \mathrm{~g} / \mathrm{m}^{3}\right)$, which is the threshold limit value for nuisance respirable particulates as set by the American Conference of Governmental Industrial Hygienists (Ref. D3). Enrichment factors, which varied according to the portion of the canyon being considered, were taken from Ref. Dl. These factors are listed in Table D-II.

Also shown in up Table D-II is the estimated length of time needed to clean that portion of the canyon system. These times were calculated by multiplying the total time of 1462 hours by the fraction that canyon strata represented of the total cleanup volume. This procedure assigns equal weighting to each unit volume taken from each stratum. Clearly, the more inaccessible areas in middle Pueblo and Acid Canyons may take longer to clean, for example, than the flatter areas in lower Pueblo Canyon. However, this would not affect the 
TABLE D-II

PARAMETERS USED IN DOSE CALCULATIONS FOR CLEANUP WORKERS

\begin{tabular}{lcc} 
Channel Section & $\begin{array}{c}\text { Enrichment } \\
\text { Factor }^{\mathrm{a}}\end{array}$ & $\begin{array}{c}\text { Time Needed } \\
\text { for Cleanup (hours) }\end{array}$ \\
\hline Acid & & 2 \\
Active Channel & 2.3 & 2 \\
Banks & 2.3 & 20 \\
Middle Pueblo & & 123 \\
Active Channel & 2.3 & \\
Banks & 2.3 & 107 \\
Lower Pueblo & & 357 \\
Active Channel & 6.2 & 102 \\
Inactive Channel & 2.3 & 288 \\
Banks & 2.3 & 425 \\
Low Los Alamos & & 36 \\
Active Channel & 1.9 & \\
Inactive Channel & 2.3 & \\
Banks & 2.3 &
\end{tabular}

aTaken from Table E-XII, Reference 1.

bBased on Table E-VI, Reference 1, and the estimate of a total of 1462 hours needed to do the entire cleanup. 
inhalation doses because the time needed for the actual cleanup would be approximately the same. Given the uncertainties of other factors used here, particularly the mass loading, this procedure gives a realistic means of proportioning the time spent in each area.

Dose conversion factors were taken from Ref. D1. These factors, when multiplied by the radionuclide intake, give the 50-yr dose commitment resulting from the intakes. The 50-yr dose commitment is used because many radionuclides considered here remain in the body and continue to irradiate long after their intake. Use of the 50-yr dose commitment accounts for this, since it represents the total dose resulting from an intake that an organ receives in the 50 years following that intake.

Doses from above-background external radiation were calculated using the measured radiation fields given in Table E-XI of Ref. Dl and the calculated exposure times.

\subsection{Dose to a Truck Driver}

Truck drivers will spend approximately $7.6 \%$ of their time at the cleanup site. The remaining time will be spent driving to and from the radioactive waste disposal site and emptying loads of soil at the site.

The final radioactive waste disposal site for soil from the canyon system has not been named. However, to make these estimates, calculations were performed as if the soil would be disposed of at TA-54 (the Laboratory site), even though TA-54 does not have the capacity to handle waste disposal such a large volume of waste.

At the cleanup site, drivers will have the same respiratory protection as the cleanup workers. Consequently, their doses from soil inhalation and exposure to external radiation will be $7.6 \%$ of that incurred by workers.

While transporting soil to TA-54, drivers will be exposed to external radiation from gamma-emitting radionuclides in the soil for approximately $636 \mathrm{~h}$ of the 1462-h cleanup operation. We used external radiation dose conversion factors, calculated to give the dose at $3 \mathrm{ft}$ above an infinite, uniformly contaminated half-space, to conservatively estimate the external dose rate in the cab from the load of soil (Ref. D4). Area averaged soil concentrations presented in Table D- $\Pi$ were used in applying these factors. 


\subsection{Doses to Workers Resulting from Construction of the Sediment Trap}

Based on estimates of the contaminated area affected by the sediment trap, doses to construction workers were taken to be $29 \%$ of the dose to workers cleaning up lower Pueblo Canyon (which is $73 \%$ of the total dose from cleaning up the Acid/Pueblo/Los Alamos Canyon system). Similarly, the dose to truck drivers is expected to be $29 \%$ of the dose to truck drivers from the cleanup of lower Pueblo Canyon. This percentage is based on the conservative assumption that all the surface area excavated for the sediment trap has abovebackground radionuclide concentrations.

\subsection{DOSES TO THE GENERAL PUBLIC}

\subsection{Construction of a Sediment Trap}

The proposed location of the sediment trap is at least $3 \mathrm{~km}$ from any residential areas. Because of the distance, concentrations of airborne radioactivity resuspended by construction activities are estimated to be small. Inhalation doses to passing motorists would be larger; however, the short exposure time also keeps those doses small. As in Sec. 3.1.1, we assumed a mass loading of $5000 \mu \mathrm{g} / \mathrm{m} 3$ for areas within $100 \mathrm{~m}$ of the construction site and used meteorological dispersion calculations to obtain the mass loading beyond $100 \mathrm{~m}$. The motorist was assumed to travel at $65 \mathrm{~km} / \mathrm{h}$ for 4 trips per day for the 20 days during which the contaminated soil would be excavated.

External radiation does were calculated in a manner described in Sec. 3.2.

\subsection{Total Cleanup}

Inhalation doses were calculated for individuals living along the lower Los Alamos Canyon stream bed during the cleanup. While the cleanup operation was within $100 \mathrm{~m}$ of the residence, the individuals were assumed to experience local mass loading of $5000 \mu \mathrm{g} / \mathrm{m}^{3}$. Beyond $100 \mathrm{~m}$, the mass loading was calculated from a meteorological dispersion model assuming $D$ stability and a wind speed of $3 \mathrm{~m} / \mathrm{s}$ and using dust resuspension rates taken from Ref. 1 for $10 \%$ soil moisture and a 3.8\% silt content (Ref. D5 ). A conservative assumption was that the residence was downwind from the work area for the entire project. Airborne radionuclide concentrations were calculated from the mass loading, soil radionuclide 
concentrations, and enrichment factors in Table D-II. A breathing rate of $0.020 \mathrm{~m}^{3} / \mathrm{min}$, typical of an adult doing light work (Ref. D2), was then used to estimate the amount of radioactivity inhaled. Finally, dose conversion factors from Ref. Dl were used to obtain the 50-year dose commitment.

The maximum external radiation dose for a member of the public was estimated by assuming that three times a day during the entire project a person drove a car next to a truck carrying soil containing residual radioactivity to the waste disposal site. The dose rate in the cab of the truck is assumed to apply in the car as well. The total whole body dose is 0.042 mrem, where a conversion of $1 \mathrm{mrem}=0.95 \mathrm{mR}$ has been used.

\subsection{No Action}

Most doses under this alternative were presented in Ref. Dl and are reproduced in Table III of this report. The doses reported in this report (Table V) are based on the results of two hydrological modeling studies (Refs. D6 and D7) that have recently become available. These studies predicted the patterns of plutonium redistribution from the 50-year flood and from annual flow.

Physical redistribution of radioactivity in the canyon system by erosive processes would result in revising annual dose estimates from Ref. 1. Where this was done, the same dose calculation procedure originally used in Ref. $\mathrm{Dl}$ was also used here. The revised dose, given in Table $\mathrm{V}$, reflects only the change in the soil/sediment concentrations. The dose calculations are described in Appendix E of Ref. D1.

The modeling studies provided estimates of plutonium discharge into the Rio Grande, and the doses to downstream users of the Rio Grande also were calculated. These doses were estimated using a calculational model recommended by the US Nuclear Regulatory Commission in Regulatory Guide 1.109 (Ref. D8). Doses were calculated for

1. use of the Rio Grande as a source of drinking water,

2. consumption of fish from the Rio Grande,

3. consumption of produce irrigated by water from the Rio Grande, and consumption of meat from animals watered in the Rio Grande and grazed on pasture irrigated by the Rio Grande, and 
4. exposure to shoreline radioactivity.

Parameters that were used in applying this model to the assessment are summarized in Table D-III.

The model was slightly modified by including a reduction factor for ingestion of produce with surface contamination to account for removal of radioactivity by washing the produce.

In calculating the radionuclide concentrations in the Rio Grande from the 50 -year flood, a dilution caused by the 50000 acre-feet of water stored in the Cochiti Reservoir was included. The dilution was taken into account because use of Rio Grande water between the Los Alamos Canyon discharge point and Cochiti Reservoir is very limited. (An inquiry made to the New Mexico State Engineer's Office concerning water rights along this stretch of river indicated no frequent users.) Significant use of the river water is expected only after the water has entered, and been diluted by, the reservoir.

For annual discharge, a reduction in radionuclide concentrations caused by dilution of Cochiti Reservoir was not applied. For a scenario of continuous annual release to the Rio Grande, a conservative first approximation would be that an equilibrium would eventually occur between the radionuclide concentrations in the water entering the reservoir and the concentrations in the reservoir water itself, as well as that leaving the reservoir. This assumption is conservative in that it ignores the reduction in these radionuclide concentrations that may take place in the reservoir because of sediment bearing increased amounts of radioactivity settling out. 
TABLE D-III

PARAMETERS USED TO ESTIMATE DOSES FROM USE OF WATER FROM THE RIO GRANDE

\begin{tabular}{|c|c|c|}
\hline Parameter & $\begin{array}{l}\text { Assigned } \\
\text { Value }\end{array}$ & Reference \\
\hline Flow rate for Rio Grande at Otowi $(\mathrm{F})^{\mathrm{a}}$ & $31.7 \mathrm{~m}^{3}\left(1119 \mathrm{ft}^{3} / \mathrm{sec}\right)$ & 9 \\
\hline $\begin{array}{l}\text { Sediment Transport Rate for } \\
\text { Rio Grande at Otowi }\end{array}$ & 71600 grams/sec & 9 \\
\hline Fraction of Year Crops are Irrigated $\left(f_{i}\right)$ & 1.0 & $\mathrm{~b}$ \\
\hline $\begin{array}{l}\text { Shoreline Width Factor for Cochiti } \\
\text { Reservoir (W) }\end{array}$ & 0.3 & 8 \\
\hline \multicolumn{3}{|l|}{ Mixing Ratios } \\
\hline Drinking Water & 1.0 & $\mathbf{b}$ \\
\hline Aquatic Food & 1.0 & b \\
\hline Shoreline Deposit & 1.0 & $\mathbf{b}$ \\
\hline Irrigated Food & 1.0 & $\mathbf{b}$ \\
\hline Effective Surface Density of Soil (P) & $240 \mathrm{~kg}$ (dry soil) $/ \mathrm{m}^{2}$ & 8 \\
\hline \multicolumn{3}{|l|}{$\begin{array}{l}\text { Fraction of Deposited Activity Retained } \\
\text { on Crops }(R)\end{array}$} \\
\hline Pasture & 0.57 & 10 \\
\hline Produce & 0.25 & 8 \\
\hline \multicolumn{3}{|l|}{ Agricultural Productivity $\left(\mathrm{Y}_{\mathrm{V}}\right)$} \\
\hline Pasture & 0.28 & 10 \\
\hline Produce & $2.0 \mathrm{~kg}$ (wet weight) $/ \mathrm{m}^{2}$ & 8 \\
\hline $\begin{array}{l}\text { Half Time for Removal of Radioactivity on } \\
\text { Plant Surfaces }\end{array}$ & 14 days & 8 \\
\hline $\begin{array}{l}\text { Consumption Rate of Contaminated Water } \\
\text { by Animal }\left(Q_{A w}\right)\end{array}$ & 50 liters/day & 8 \\
\hline $\begin{array}{l}\text { Consumption Rate of Contaminated Feed } \\
\text { by Animal }\left(\mathrm{Q}_{\mathrm{F}}\right)\end{array}$ & $11.9 \mathrm{~kg}$ (dry weight)/day & 11 \\
\hline Sediment/Soil Exposure Time $\left(t_{b}\right)$ & 70 years & $\mathrm{b}$ \\
\hline \multicolumn{3}{|l|}{ Crop Growing Season Exposure Time $\left(t_{\mathrm{e}}\right)$} \\
\hline Pasture & 30 days & 8 \\
\hline Produce & 60 Days & 8 \\
\hline Harvest - Food Consumption Holdup Time $\left(t_{h}\right)$ & 0 hours & $b$ \\
\hline \multicolumn{3}{|l|}{$\begin{array}{l}\text { Transit Time for Radionuclide to Reach Point } \\
\text { of Exposure }\end{array}$} \\
\hline Drinking Water & 0 hours & $\mathrm{b}$ \\
\hline Aquatic Food & 0 hours & $\mathrm{b}$ \\
\hline Shoreline Deposits & 0 hours & $\mathbf{b}$ \\
\hline Irrigated Food & 0 hours & $\mathrm{b}$ \\
\hline \multirow[t]{2}{*}{ Annual Application Rate of Irrigated Water } & $0.635 \mathrm{~m}^{3}$ of water & 12 \\
\hline & $\mathrm{m}^{2}$ of soil & \\
\hline $\begin{array}{l}\text { Fraction of Radioactivity Removed from } \\
\text { Produce Surface }\end{array}$ & 0.5 & 13 \\
\hline
\end{tabular}




\section{REFERENCES}

1. Los Alamos National Laboratory, "Radiological Survey of the site of a Former Radioactive Liquid Waste Treatment Plant (TA-45) and the Effluent Receiving Areas of Acid, Pueblo, and Los Alamos Canyons, Los Alamos, New Mexico," Department of Energy report DOE/EV-0005/30 (May 1981).

2. International Commission on Radiological Protection, "Report of the Task Force on Reference Man," ICRP Publication 23, Pergamon Press, New York (1975).

3. American Conference of Governmental Industrial Hygienists, "Threshold Limit Values and Biological Exposure Indices for 1982-83," Cincinnatti, Ohio (1982).

4. H. L. Beck, J. DeCampo, and G. Gogolak, "In Situ Ge(Li) and NaI (Tl) Gamma-Ray Spectrometry," US Health and Safety Laboratory report HASL-258 (September 1972).

5. K. Axetell, Jr., and C . Cowherd, Jr ., "Improved Emission Factors for Fugitive Dust from Western Surface Coal Mining Sources," Industrial Environmental Research Laboratory, Final Report to US Environmental Protection Agency, Contract No. 6803-2924 (November 1981). (Available from U. S. Environmental Protection Agency, Washington, D.C.)

6. L. J. Lane, W. D. Purtymun, and N. M. Becker, "New Estimating Procedures for Surface Runoff, Sediment Yield, and Contaminant Transport in Los Alamos County, New Mexico," Los Alamos National Laboratory report LA-10335-MS (April 1985).

7. G. Whelan, F. L. Thompson, and S. B. Yabusaki, "Multimedia Contaminant Environmental Exposure Assessment Methodology as Applied to Los Alamos, New Mexico," Battelle Pacific Northwest Laboratory report PNL-4546 (February 1983).

8. US Nuclear Regulatory Commission, "Calculation of Annual Doses to Man from Routine Releases of Reactor Effluents for the Purpose of Evaluating Compliance with 10 CFR Part 50, Appendix I," USNRC Regulatory Guide 1.109 (October 1977). 
9. US Geological Survey, "Water Resources Data for New Mexico." Water-Data report NM-79-1 (1980).

10. R. E. Moore, C. F. Baes III, L. M. McDowell-Boyer, A. P. Watson, F. O. Hoffman, J. C. Pleasant, and C. W. Miller, "AIRDOS-EPA, A Computerized Methodology for Estimating Environmental Concentrations and Doses to Man from Airborne Releases of Radionuclides," Oak Ridge National Laboratory report ORNL-5532 (1979).

11. W. J. Wenzel, K. M. Wallwork-Barber, J. M. Horton, K. H. Rea, L. C. Hollis, E. S. Gladney, D. L. Mayfield, A. F. Gallegos, J. C. Rodgers, R. G. Thomas, and G. Trujillo, "Supplementary Documentation for an Environmental Impact statement Regarding the Pantex Plant. Agricultural Food Chain Radiological Assessment," Los Alamos National Laboratory report LA-9445-PNTXM (December 1982).

12. B. J. Creel and R. R. Lansford, "Agricultural Resource Base Data for Environmental Evaluation of Toxic Waste Burial sites and Their Ultimate Disposition," Department of Agricultural Economics and Agricultural Business, Agricultural Experiment Station, New Mexico State University report (July 1975).

13. US Nuclear Regulatory Commission, "Calculational Models for Estimating Radiation Doses to Man from Airborne Radioactive Materials Resulting from Uranium Milling Operations," USNRC Regulatory Guide 3.51 (March 1982). 